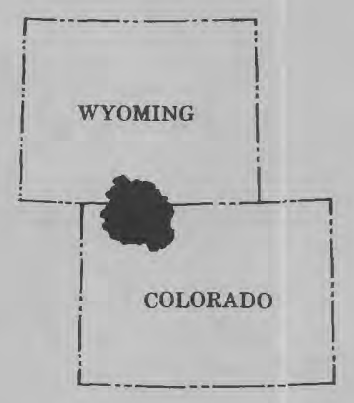

UNITED STATES

DEPARTMENT OF THE INTERIOR

GEOLOGICAL SURVEY

\title{
ANALYSIS OF WASTE-LOAD ASSIMILATIVE CAPACITY OF THE YAMPA RIVER, STEAMBOAT SPRINGS TO HAYDEN, ROUTT COUNTY, COLORADO
}

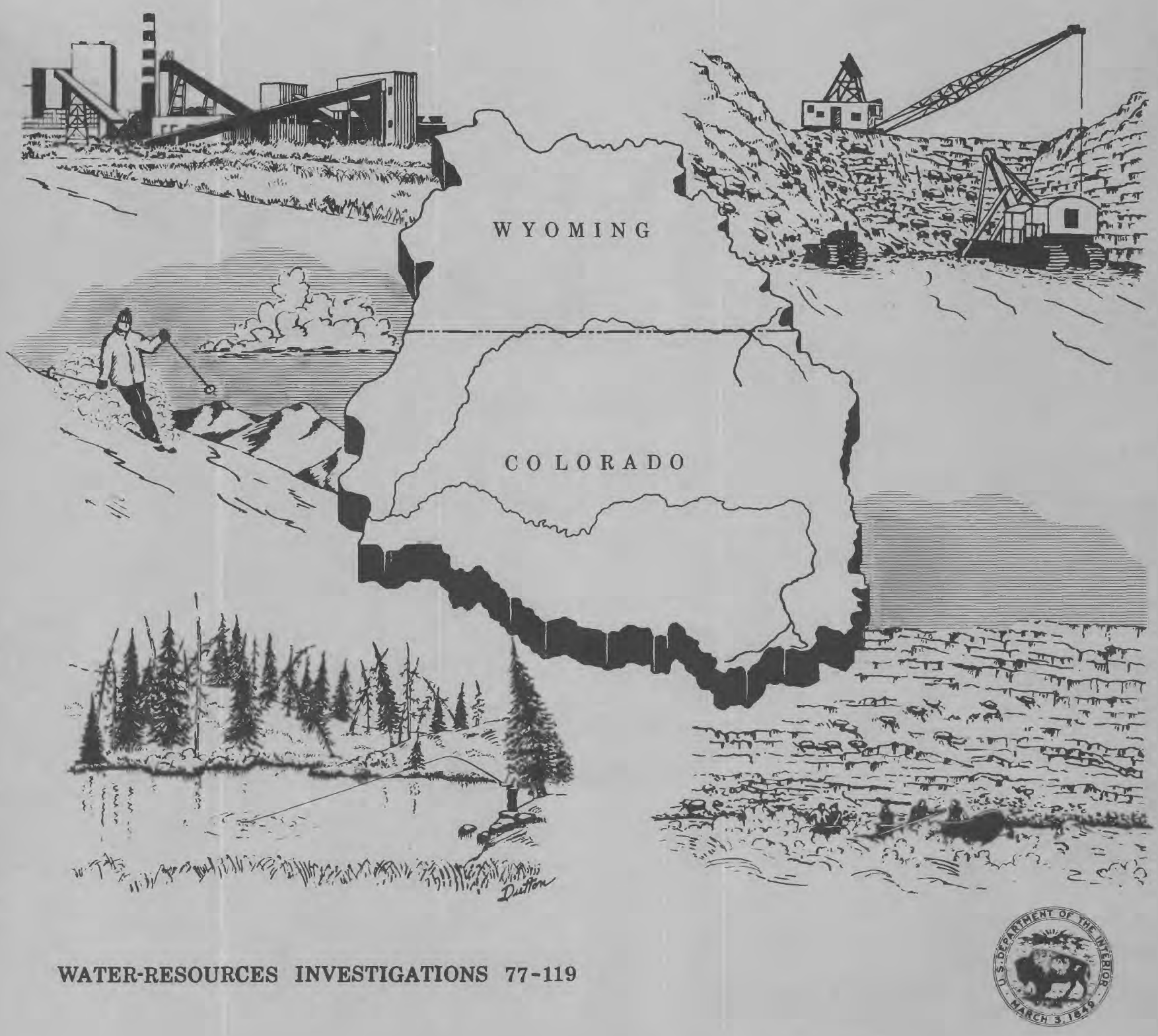




\begin{tabular}{|c|c|c|}
\hline $\begin{array}{l}\text { BIBLIOGRAPHIC DATA } \\
\text { SHEET }\end{array}$ & 1. Report No. & 3. Recipient's Accession No. \\
\hline \multicolumn{2}{|l|}{ 4. Title and Subtitle } & $\begin{array}{l}\text { 5. Report Date } \\
\text { March } 1978\end{array}$ \\
\hline \multicolumn{2}{|c|}{$\begin{array}{l}\text { Analysis of Waste-Load Assimilative Capacity of the Yampa } \\
\text { River, Steamboat Springs to Hayden, Routt County, Colorado }\end{array}$} & 6. \\
\hline \multicolumn{2}{|c|}{$\begin{array}{l}\text { 7. Author(s) } \\
\text { Danie1 P. Bauer, Timothy D. Steele, and Richard D. Andersor }\end{array}$} & $\begin{array}{l}\text { 8. Performing Organization Rept. } \\
\text { No. USGS/WRI }-77-119\end{array}$ \\
\hline \multicolumn{2}{|c|}{$\begin{array}{l}\text { 9. Performing Organization Name and Address } \\
\text { U.S. Geological Survey, Water Resources Division } \\
\text { Box 25046, Mail Stop 415 } \\
\text { Denver Federal Center } \\
\text { Lakewood. Colorado } 80225\end{array}$} & 11. Contract/Grant No. \\
\hline \multirow{2}{*}{\multicolumn{2}{|c|}{$\begin{array}{l}\text { 12. Sponsoring Organization Name and Address } \\
\text { U.S. Geological Survey, Water Resources Division } \\
\text { Box 25046, Mail Stop } 415 \\
\text { Denver Federal Center } \\
\text { Lakewood, Colorado } 80225\end{array}$}} & $\begin{array}{l}\text { 13. Type of Report \& Period } \\
\text { Covered } \\
\text { Final }\end{array}$ \\
\hline & & 14. \\
\hline
\end{tabular}

15. Supplementary Notes

Prepared in cooperation with the Routt County Department of Environmental Health

16. Abstracts An analysis of the waste-load assimilative capacity of the Yampa River from Steamboat Springs to Hayden, Colo., was made to obtain information on the effects of projected waste loadings on this stream reach. Simulations of effects of waste loadings on streamflow quality were made using a steady-state water-quality model. The simulations were based on 7-day low-flow values with a 10-year recurrence interval and population projections for 2010. Mode1 results for December and September streamflow conditions indicated that a recommended water-quality standard of 0.02 milligram per liter for nonionized ammonia concentration would be exceeded. Model simulations also included the effect of a flow augmentation of 20 cubic feet per second ( 0.56 cubic meter per second) from a proposed upstream reservoir. The permissible ammonia $10 a d i n g$ in the study reach could be increased approximately 25 percent with this amount of flow augmentation. Simulations of concentrations of other water-quality variables indicated that water-quality goals proposed for 1978, 1983, or 1985 would not be exceeded.

17. Key Words and Document Analysis. 17a. Descriptors

Colorado, Computer models, Data collection, Invertebrates, Low-flow augmentation, Model studies, Nutrients, Simulation analysis, Standards, Waste assimilative capacity, Water pollution control, Water Quality Act, Water storage, Water treatment

17b. Identifiers/Open-Ended Terms

Benthic-invertebrate diversity, Cold-water fishery, Computational algorithms, Nonionized ammonia, Population projection, Seasonal conditions, Steady-state water-quality model, Steamboat Springs, Colo., Yampa River basin (Colorado-Wyoming)

17c. COSATI Field 'Group

18. Availability Statement

No restriction on distribution.

\begin{tabular}{|l|c|}
$\begin{array}{l}\text { 19. Security Class (This } \\
\text { Report) } \\
\text { UNCLASSIFIED }\end{array}$ & $\begin{array}{c}\text { 21. No. of Pages } \\
76\end{array}$ \\
\hline $\begin{array}{l}\text { 20. Security Class (This } \\
\text { Page } \\
\text { UNCLASSIFIED }\end{array}$ & 22. Price \\
\hline
\end{tabular}


ANALYSIS OF WASTE-LOAD ASSIMILATIVE CAPACITY OF THE YAMPA RIVER, STEAMBOAT SPRINGS TO HAYDEN, ROUTT COUNTY, COLORADO

By Danie1 P. Bauer and Timothy Doak Steele, U.S. Geological Survey, and Richard D. Anderson, Colorado Department of Health

U.S. GEOLOGICAL SURVEY

Water-Resources Investigations 77-119

Prepared in cooperation with the

Routt County Department of Environmental Health 
UNITED STATES DEPARTMENT OF THE INTERIOR

CECIL D. ANDRUS, Secretary

GEOLOGICAL SURVEY

W. A. Radlinski, Acting Director

For additional information write to:

District Chief

U.S. Geological Survey

Box 25046, Mail Stop 415

Denver Federal Center

Denver, Colorado 80225 
Metric conversion factors. . . . . . . . . . . . . . . . . . VI

Abstract . . . . . . . . . . . . . . . . . . . . . . . . . . . 1

Introduction . . . . . . . . . . . . . . . . . . . . . . . . . . . 1

Purpose and scope... . . . . . . . . . . . . . . . 2

Acknowledgments . . . . . . . . . . . . . . . . . . 2

Previous investigations . . . . . . . . . . . . . . . . . 4

Description of study reach . . . . . . . . . . . . . . . . . . . . 4 4

Description of water-quality models used for analysis. . . . . . . . . . 11

U.S. Geological Survey model. . . . . . . . . . . . . . . . 11

Pioneer-I model . . . . . . . . . . . . . . . . . . . . 11

Data used for model calibration. . . . . . . . . . . . . . . . 12

Data-collection program . . . . . . . . . . . . . . . 12

Stream-reach and diel variations. . . . . . . . . . . . . . . 14

Data-reduction techniques . . . . . . . . . . . . . . . . 20

Calibration results. . . . . . . . . . . . . . . . . . . . 20

Factors incorporated into model simulations. . . . . . . . . . . . . . . 35

Existing stream-reach classification. . . . . . . . . . . . 35

Effluent standards of proposed regional wastewater-treatment plant. 38

Flow augmentation of proposed Yamcolo Reservoir . . . . . . . . . . 40

Population projections for Steamboat Springs. . . . . . . . . . . . 40

Model simulations. . . . . . . . . . . . . . . . . . . . . 42

Effluents from existing wastewater-treatment plants and 7-day,

10-year streamflow. . . . . . . . . . . . . . . . . 42

Proposed regional wastewater-treatment plant with 1978 standards

for effluent. . . . . . . . . . . . . . . . . . . 44

Proposed regional wastewater-treatment plant with 1985 standards

for effluent. . . . . . . . . . . . . . . . . . 56

Ammonia-nitrogen concentrations for varying conditions and 1978

standards for effluent. . . . . . . . . . . . . . 56

Stream biological conditions . . . . . . . . . . . . . . . . 61

Summary. . . . . . . . . . . . . . . . . . . . . . . 65

References . . . . . . . . . . . . . . . . . . . . 67

\section{ILLUSTRATIONS}

Figure 1. Map showing location and areal extent of the Yampa River basin and location of study reach . . . . . . . . . .

2-5. Graphs showing:

2. Daily-mean discharges, Yampa River at Steamboat Springs, 1975 water year. . . . . . . . . . .

3. Daily-mean discharges, Yampa River downstream from diversion near Hayden, 1975 water year. . . . . . .

4. Annual-mean and mean-annual discharges, Yampa River at Steamboat Springs $(1905-06,1910-77)$. . . . . . . 7

5. Mean-monthly discharges, Yampa River at Steamboat Springs (1905-06, 1910-77). . . . . . . . 
Figure 6. Map showing location of sampling sites, study reach of Yampa

River, September 23-24, 1975 . . . . . . . . .

7-39. Graphs showing:

7. Mean temperature and mean concentrations of selected water-quality constituents in the Yampa River, September 23-24, 1975 . . . . . . . . . . .

8. Concentrations of total-coliform and fecal-coliform bacteria in the Yampa River, September 23-24, 1975. .

9. Diel variation in concentrations of total-coliform and fecal-coliform bacteria in the Yampa River downstream from campgrounds near Steamboat Springs, site YM-4, September 23-24, 1975 . . . . . . . . . . . .

10. Diel variation in concentrations of dissolved oxygen at selected sites on the Yampa River, September 23-24, 1975 . . . . . . . . . . . . . . .

11. Least-squares method of calculating decay rates and concentrations of biochemical oxygen demand, Yampa River downstream from Steamboat II near Steamboat

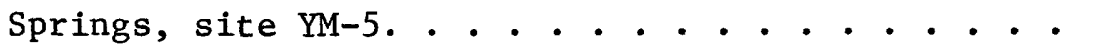

12. Decay rate of carbonaceous biochemical oxygen demand for given subreaches downstream from reference location YM-4, Yampa River, Steamboat Springs area, September 23-24, 1975 . . . . . . . . . . .

13. Die-off rates of total-coliform and fecal-coliform bacteria for given subreaches downstream from reference location YM-4, Yampa River, Steamboat Springs area, September 23-24, 1975 . . . . . . . .

14. Computed versus observed concentrations of ultimatecarbonaceous biochemical oxygen demand in the Yampa River, September 23-24, 1975. . . . . . . . .

15. Computed versus observed concentrations of dissolved oxygen in the Yampa River, September 23-24, 1975. . .

16. Computed versus observed concentrations of organic nitrogen in the Yampa River, September 23-24, 1975. .

17. Computed versus observed concentrations of ammonia nitrogen in the Yampa River, September 23-24, 1975. .

18. Computed versus observed concentrations of nitrite plus nitrate as nitrogen in the Yampa River, September 23-24,1975 .............

19. Computed versus observed concentrations of total nitrogen in the Yampa River, September 23-24, 1975. .

20. Computed versus observed concentrations of orthophosphate in the Yampa River, September 23-24, 1975 . . .

21. Computed versus observed concentrations of fecalcoliform bacteria in the Yampa River, September 23-24, 1975 ..................

22. Computed versus observed concentrations of totalcoliform bacteria in the Yampa River, September 23-24, 1975 . . . . . . . . . . . . 
Figures 23-39. Graphs--Continued

Page

23. Peak-day and permanent population projections for the Steamboat Springs area..............

24. Computed concentrations of ultimate-carbonaceous biochemical oxygen demand for existing wastewatertreatment facilities and Q7,10-flow conditions in the Yampa River . . . . . . . . . . . . .

25. Computed concentrations of dissolved oxygen for existing wastewater-treatment facilities and Q7,10-flow conditions in the Yampa River. . . . . .

26. Computed concentrations of ammonia nitrogen for existing wastewater-treatment facilities and Q7,10-flow conditions in the Yampa River. . . . . .

27. Computed concentrations of fecal-coliform bacteria for existing wastewater-treatment facilities and Q7,10-flow conditions in the Yampa River. . . . . .

28. Computed concentrations of ultimate-carbonaceous biochemical oxygen demand using 1978 standards for effluent, Yampa River . . . . . . . . . . .

29. Computed concentrations of dissolved oxygen using 1978 standards for effluent, Yampa River. . . . . . 50

30. Computed concentrations of ammonia nitrogen using 1978 standards for effluent, Yampa River. . . . . . 51

31. Computed concentrations of total nitrogen using 1978 standards for effluent, Yampa River. . . . . . 52

32. Computed concentrations of orthophosphate using 1978 standards for effluent, Yampa River. . . . . . .

33. Computed concentrations of nonionized ammonia nitrogen using 1978 standards for effluent, Yampa River, assuming 9 milligrams per liter (December) and 2.8 milligrams per liter (September) of ammonia nitrogen in effluent from wastewater-treatment plant . . . .

34. Computed concentrations of ammonia nitrogen in the Yampa River, assuming 3.0 and 4.0 milligrams per liter of ammonia in effluent from wastewatertreatment plant............ 55

35. Computed concentrations of fecal-coliform bacteria using 1978 standards for effluent, Yampa River. . .

36. Computed concentrations of ammonia nitrogen using 1985 standards for effluent, Yampa River. . . . . . 58

37. Computed concentrations of total nitrogen using 1985 standards for effluent, Yampa River . . . . . . .

38. Mean diversity of benthic invertebrates and nutrient concentrations, Yampa River . . . . . . . . . 63

39. Mean total number of organisms per square meter and nutrient concentrations, Yampa River. . . . . . . 
Table 1. Existing point-source discharges from wastewater-treatment plants . . . . . . . . . . . . . . . . . . 9

2. Sampling-site locations, September 23-24, 1975 . . . . . . . . 13

3. Nonionized ammonia $\left(\mathrm{NH}_{3}\right)$ for observed $\mathrm{pH}$ and temperature

Page values, Yampa River, September 23-24, 1975 . . . . . . . . 33

4. Percentage of nonionized ammonia nitrogen in ammonia-water solutions at various $\mathrm{pH}$ and water-temperature values . . . .

5. Suggested effluent standards for proposed regional wastewatertreatment plant. . . . . . . . . . . . . . . . . .

6. Maximum computed concentrations of ammonia nitrogen and nonionized ammonia nitrogen for permanent populations, and using 1978 standards for effluent, Yampa River, Steamboat Springs to Hayden, Colo. . . . . . . . . . . . . . .

7. Maximum computed concentrations of ammonia nitrogen and nonionized ammonia nitrogen for peak-day populations, and using 1978 standards for effluent, Yampa River, Steamboat Springs to Hayden, Colo. . . . . . . . . . . . . . .

8. Periphyton data, Yampa River, Steamboat Springs to Hayden, Colo., August-September 1975 . . . . . . . . . . . .

\section{METRIC CONVERSION FACTORS}

The English units used in the text of this report are followed by metric units; others may be converted to metric units by using the following conversion factors:

To convert English units

foot ( $f t)$

foot per mile ( $\mathrm{ft} / \mathrm{mi}$ )

cubic foot per second $\left(\mathrm{ft}^{3} / \mathrm{s}\right)$

mile (mi)

square mile $\left(\mathrm{mi}^{2}\right)$

gallon per minute (ga1/min)
Muztiply by

0.3048

.1894

.02832

1.609

2.590

$6.309 \times 10^{-5}$
To obtain metric units

meter (m)

meter per kilometer $(\mathrm{m} / \mathrm{km})$

cubic meter per second $\left(\mathrm{m}^{3} / \mathrm{s}\right)$

kilometers ( $\mathrm{km})$

square kilometers $\left(\mathrm{km}^{2}\right)$

cubic meter per second $\left(\mathrm{m}^{3} / \mathrm{s}\right)$ 
ANALYSIS OF WASTE-LOAD ASSIMILATIVE CAPACITY

OF THE YAMPA RIVER, STEAMBOAT SPRINGS TO HAYDEN, ROUTT COUNTY, COLORADO

By Daniel P. Bauer and Timothy Doak Steele, U.S. Geological Survey, and Richard D. Anderson, Colorado Department of Health

\section{ABSTRACT}

An analysis of the waste-load assimilative capacity of the Yampa River from Steamboat Springs to Hayden, Colo., a distance of 38 miles (61 kilometers), was made during September 1975 to obtain information on the effects of projected waste loadings on this stream reach.

Simulations of effects of waste loadings on streamflow quality were made using a steady-state water-quality model. The simulations were based on 7-day low-flow values with a 10-year recurrence interval and population projections for 2010. Model results for December and September streamflow conditions indicated that the recommended 1978 Colorado and 1976 U.S. Environmental Protection Agency water-quality standard of 0.02 milligram per liter for nonionized ammonia concentration would be exceeded. Model simulations also included the effect of a flow augmentation of 20 cubic feet per second (0.56 cubic meter per second) from a proposed upstream reservoir. The permissible ammonia loading in the study reach could be increased approximately 25 percent with this amount of flow augmentation. Simulations of concentrations of dissolved oxygen, fecal-coliform bacteria, and nitrate nitrogen indicated that the State's water-quality goals proposed for 1978, 1983, or 1985 would not be exceeded.

A comparative analysis using the U.S. Geological Survey model and a modified Pioneer-I model, developed by Battelle Pacific Northwest Laboratories, was made with the observed data collected during September 1975. Some variation was shown between the two model results for the constituents considered.

\section{INTRODUCTION}

As a result of Public Law 92-500 (Federal Water Pollution Control Act Amendments of 1972), there are many studies now in progress for implementing areawide wastewater-management plans throughout the United States. Within the 
State of Colorado, 12 regional councils of government have been established, and among their responsibilities are the coordination of studies dictated by section 208 of Public Law 92-500.

This report was prepared by the U.S. Geological Survey in cooperation with the Routt County Department of Environmental Health. The study reported herein was coordinated with the staff members of the North West Colorado Council of Governments. Both the Yampa River basin assessment by the U.S. Geological Survey (Steele and others, 1976 $\alpha$, 1976b) and the areawide wastewater-management study by the North West Colorado Council of Governments involve evaluating primary and secondary impacts of coal-resource development in their respective study areas (U.S. Department of the Interior, 1976). The study described herein was initiated because of impending population growth in the Steamboat Springs area and the concern for maintaining the regional environmental esthetic quality in order to meet demands for various forms of recreation (including water-based uses) of the area. The specific area of interest for this study is a reach of the Yampa River, approximately from Steamboat Springs to Hayden, located in Routt County, Colo. (fig. 1).

\section{Purpose and Scope}

The study was conducted, in part, in fulfillment of guidelines for implementing section 208 of Public Law 92-500. The primary purpose of the study was to aid in evaluating the waste-load assimilative capacity of the study reach for a minimum mean 7-day low flow and 10-year recurrence interval $(Q 7,10)$. The results of this analysis will provide planners and managers in Routt County with information for determining the waste-load capacities of the study reach for possible design and operational alternatives of future wastewater-treatment plants.

The report presents an analysis of one set of data collected during a 24hour period. These data were used to calibrate two water-quality models: A U.S. Geological Survey model and a modified Pioneer-I model developed by Battelle Pacific Northwest Laboratories. Calibration of the two models was done to evaluate the adequacy of the various model computational algorithms. The report also discusses simulation results using the U.S. Geological Survey model for alternative levels of waste loadings, Q7,10-flow conditions, and seasonal conditions during September and December. Discussion of possible relationships between measured concentrations of nutrients and observed populations of macroinvertebrates and periphyton also is included.

\section{Acknowledgments}

The authors are grateful to Phillip E. Stark and his staff, Routt County Department of Environmental Health, for assistance in the planning and execution of the field-data collection and in providing supplemental information; and to Ronald M. Eddy, Aquatic Biologist, Technical Investigations Branch, Surveillance and Analysis Division, U.S. Environmental Protection Agency, 


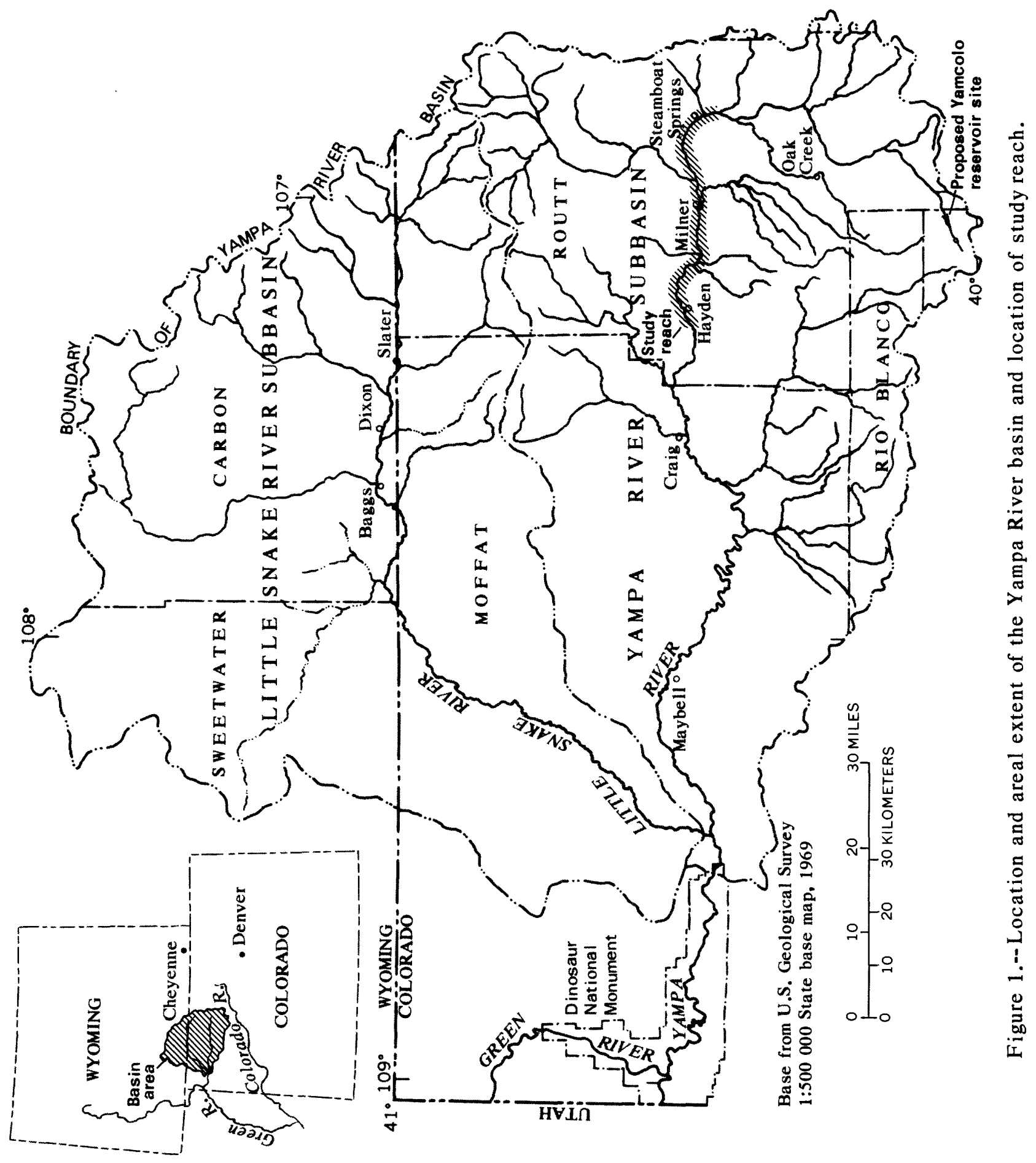


Region VIII, for coordinating an extensive evaluation of macroinvertebrates in the study reach of the Yampa River. The authors also thank the many residents of Routt County for access to the Yampa River and tributary sampling sites during the study.

\section{$\underline{\text { Previous Investigations }}$}

A study by McCal1-Ellingson and Morrill, Inc. (1974), which was completed for the Colorado Department of Health, developed a water-quality management plan for that part of the Green River basin in Colorado. Their study was designed to fulfill the requirements of section 303 (c) of Public Law 92-500. In their study, the reach of the Yampa River from Steamboat Springs to the confluence with the Elk River (fig. 1) was classified as an area with significant pollution problems, and an extensive computer-model analysis was made. Conclusions of the study by McCall-Ellingson and Morrill, Inc., were: Concentrations of ammonia nitrogen exceeded the recommended standards of the U.S. Environmental Protection Agency (National Academy of Sciences-National Academy of Engineering, 1973) for almost the entire study reach, concentrations of dissolved oxygen exceeded the minimum recommended standards of the State for the entire reach, and concentrations of fecal-coliform bacteria did not exceed recommended standards of the State. Their analysis was based upon data collected at relatively high flows during July 1972, and did not include data for low-flow conditions.

In 1974, Wright-McLaughlin Engineers conducted a study in the Mount Werner ski area, located northeast of Steamboat Springs. The purpose of the study was to evaluate the use of treated sewage effluent for snow-making on the ski slopes. Results of this study (Wright, 1976) were favorable toward the use of treated sewage in this manner. A separate summer land-treatment study was completed by Wright-McLaughlin Engineers (1974) for the Timbers Water and Sanitation District, also located near Steamboat Springs.

\section{DESCRIPTION OF STUDY REACH}

The 38-mi $(61-\mathrm{km})$ study reach of the Yampa River begins approximately $3 \mathrm{mi}(4.8 \mathrm{~km})$ east of Steamboat Springs and ends $2 \mathrm{mi}(3.2 \mathrm{~km})$ west of Hayden (fig. 1). Daily-mean discharge of the Yampa River for the 1975 water year for the gaging station at Steamboat Springs is shown on figure 2 and for the gaging station near Hayden on figure 3. Mean-annual discharge for the Yampa River at Steamboat Springs for the period of record (1905-06 and 1910-77 water years) is $464 \mathrm{ft}^{3} / \mathrm{s}\left(13.1 \mathrm{~m}^{3} / \mathrm{s}\right.$ ) ( $\mathrm{fig}$. 4). Mean-annual discharge for the 1975 water year was 9 percent higher than the long-term average (fig. 4). The variability of mean-month1y discharges for the Yampa River at Steamboat Springs for the period of record is shown on figure 5. Low flows generally occur from September to February (fig. 5). The streamflow regime for the study reach of the Yampa River during low-flow periods is pool and riffle. The slope of the channel (11 to $26.4 \mathrm{ft} / \mathrm{mi}$ or 2 to $5 \mathrm{~m} / \mathrm{km}$ ) results in long 


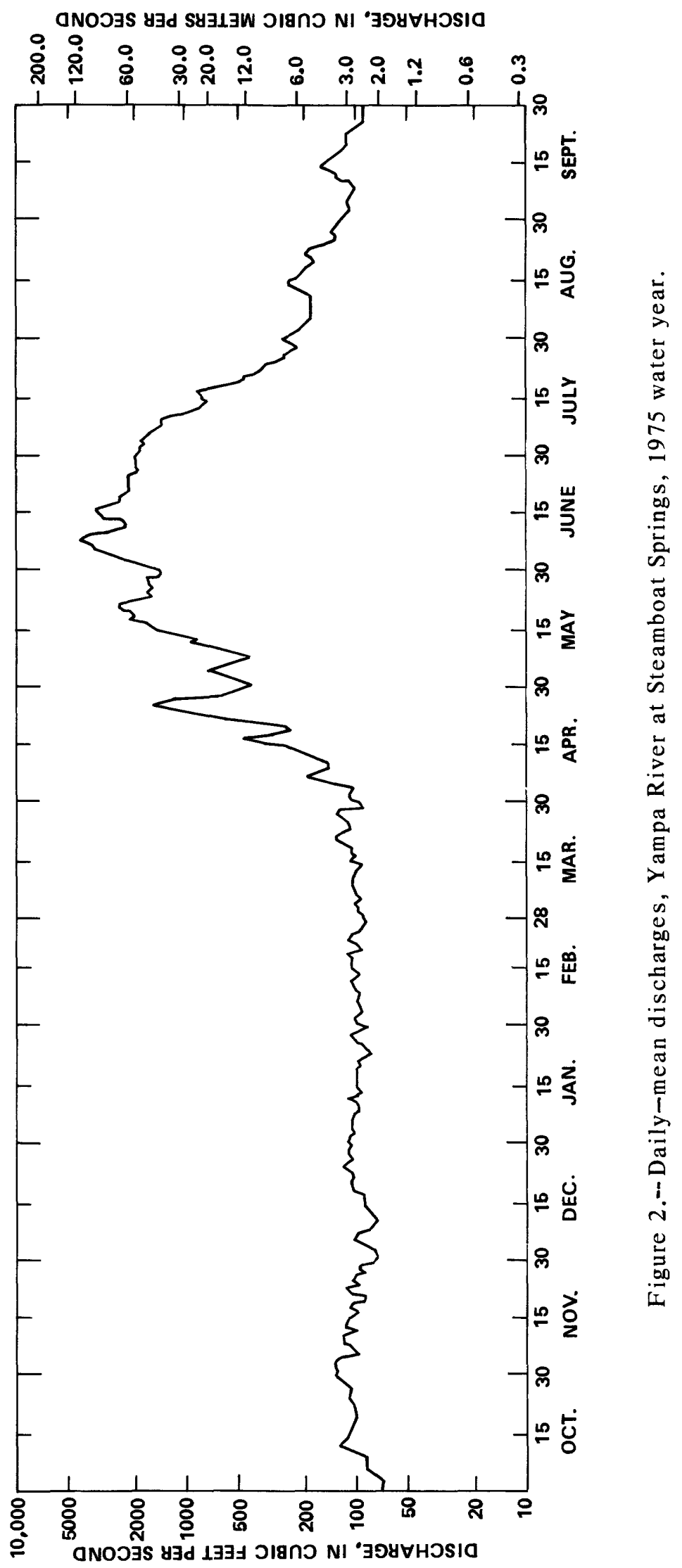




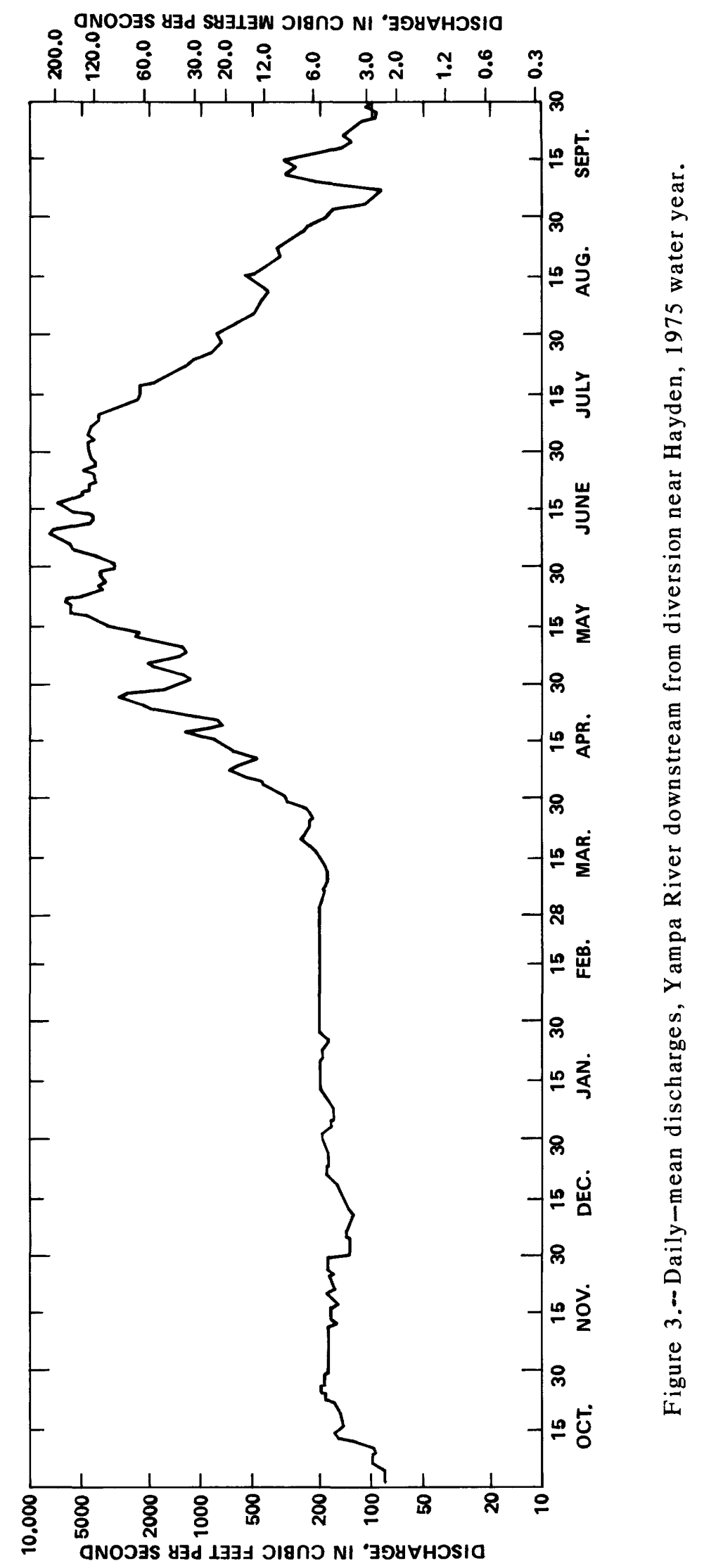




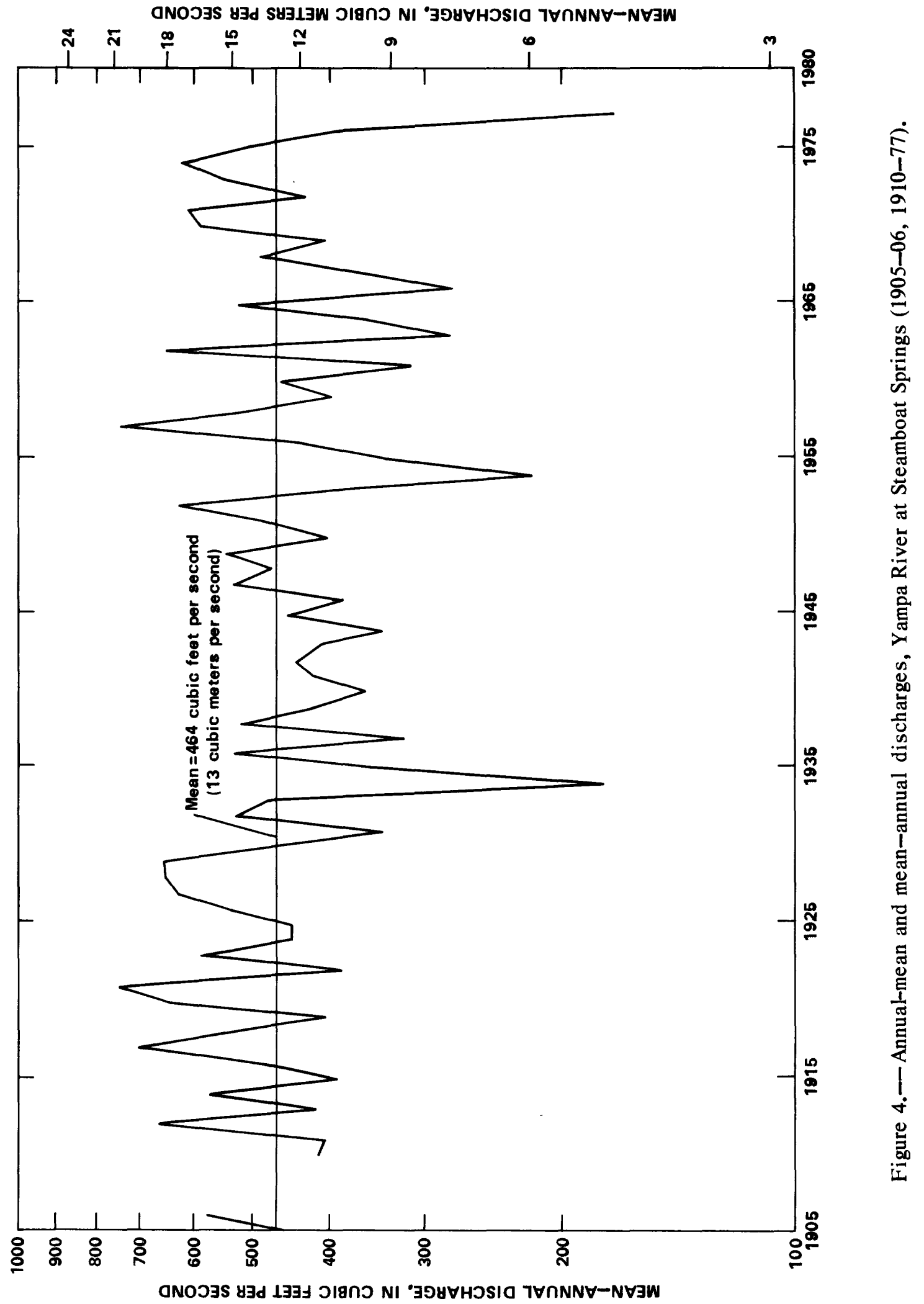




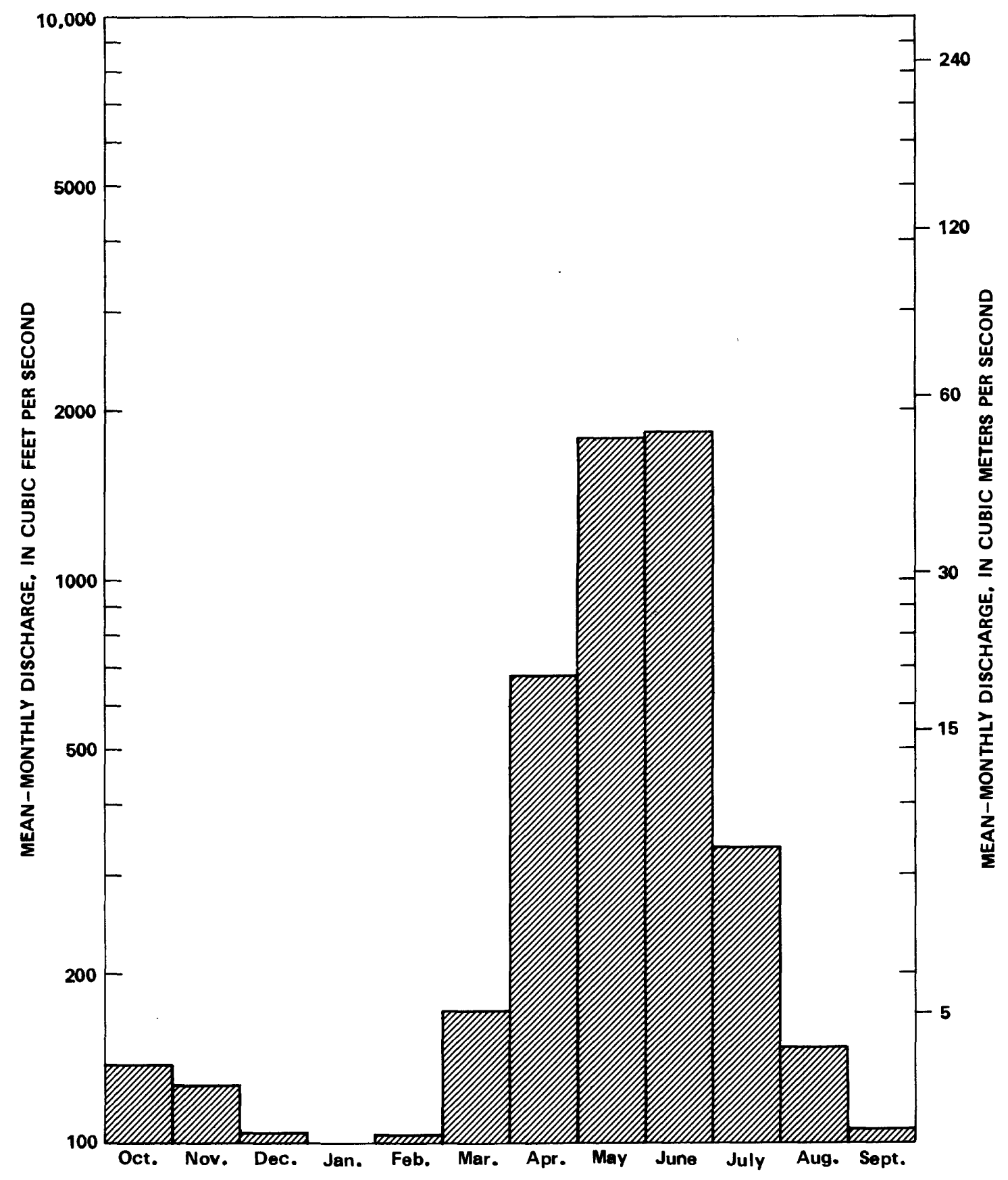

Figure 5.--Mean-monthly discharges, Yampa River at Steamboat Springs (1905-06, 1910-77). 
riffles. Annual variability in stream temperatures in this reach of the Yampa River ranges from $0^{\circ}$ to $20^{\circ} \mathrm{C}$ (Celsius) (T. D. Steele, D. P. Bauer, D. A. Wentz, and J. W. Warner, written commun., 1977). Minimum water temperatures generally occur in February and maximum temperatures in August. During the winter months, parts of the study reach may be completely covered with ice.

The locations of the sampling sites used for the modeling analysis of the study reach are shown on figure 6. Seventeen tributaries discharge into the Yampa River in this reach (fig. 6). Major tributaries include the Elk River, Trout Creek, and Walton Creek. In 1975, it was estimated that 8,000 people lived along the study reach, principally in the Steamboat Springs and Hayden areas (Gathers and Associates, Inc., 1976). Effluent discharges from municipal wastewater-treatment plants comprise the major source of organic pollution to the Yampa River in the study reach. A summary of the existing point-source discharges from wastewater-treatment plants in the study reach is presented in table 1. Until late 1975, a 180-MW (megawatt) powerplant upstream from the town of Hayden (fig. 6) discharged heated water into Sage Creek, a tributary to the Yampa River. During 1976, a second unit generating $250 \mathrm{MW}$ was added to the powerplant. At about that time, a cooling-tower and evaporation-pond type of system was installed to dispose of the heated water resulting from the operation of the entire powerplant. No thermally heated waters are now being discharged into Sage Creek from the powerplant.

Table 1.--Existing point-source discharges from wastewater-treatment plants

Reference
code $^{l}$$\quad$ Source System type Entities served

YE-1----- Mount Werner Aerated lagoon

YE-3----- Town of

Steamboat

Springs

YE-4----- KOA

YE-5----- Sleepy Bear

YE-6----- Steamboat II Package plant

YE-7----- Town of Hayden
Package plant

Package plant

Aerated lagoon
Mount Werner Water and Sanitation District, Tree Haus district.

Town of Steamboat Springs, Fish Creek Water and Sanitation District, West Steamboat Water and Sanitation District, Riverside Water and Sanitation District, and Mount Werner bypass.

KOA campground. Private system.

Sleepy Bear mobile-home park. Private system.

Steamboat II Water and Sanitation District.

Town of Hayden.

${ }^{1}$ See figure 6. 


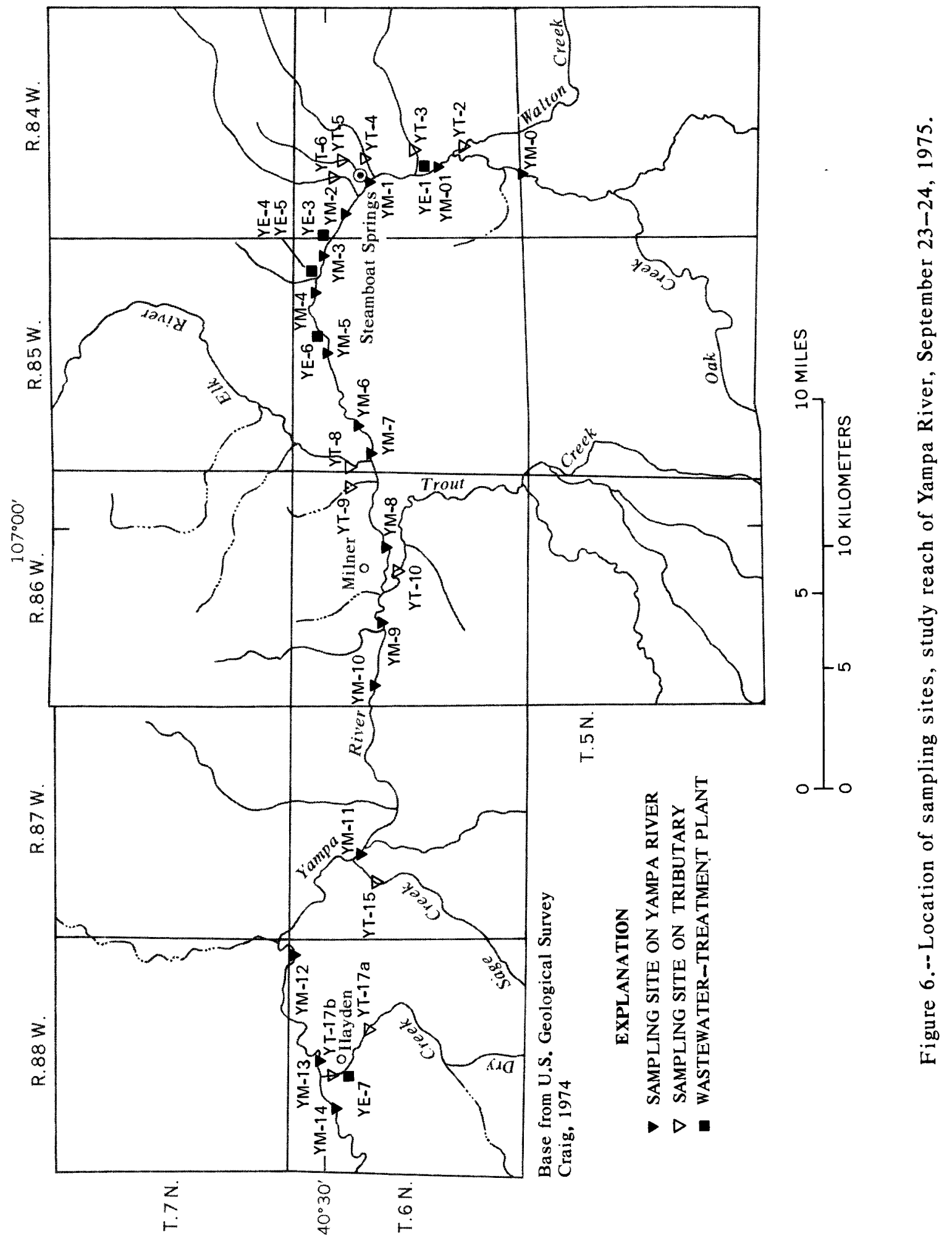


Two models were used in the calibration phase of the analysis: A U.S. Geological Survey model and a modified Pioneer-I model developed by Battelle Pacific Northwest Laboratories. The purpose of this comparison was to show any differences in the computational algorithms used in the models for the same model-parameter values.

\section{U.S. Geological Survey Model}

The U.S. Geological Survey model is documented by Bauer and Jennings (1975). The model is based upon the oxygen-sag equation of Streeter and Phelps (1925). The model is intended for use under steady-state (constant flow rate of waste and stream discharges) conditions. When applying the model to a given reach of a river, the reach is divided into a given number of subreaches, generally defined by locations where a waste or tributary inflow mixes with the river water. The formulation assumes complete mixing in a stream cross section.

Some of the original programing concepts made for this form of model have been described by Shindala (1972). The first large-scale application of this model was in Arkansas (Jennings and Bryant, 1973).

The original model (Bauer and Jennings, 1975) was expanded to include processes for determining concentrations of fecal-coliform and total-coliform bacteria, the various nitrogen components, and orthophosphate. The equations for determining concentrations of coliform bacteria that were incorporated are those described by Mahloch (1973), equations for nitrification reactions are described by Thomann (1972), and the equation for determining concentrations of orthophosphate is described by Willis, Anderson, and Dracup (1975).

\section{Pioneer-I Mode1}

The Pioneer-I model (Waddel and others, 1973) is based upon the DOSAG-I model, originally developed by the Federal Water Pollution Control Administration and modified by the Texas Water Development Board (1970). The Pioneer-I model, which also utilizes the oxygen-sag equation of Streeter and Phelps (1925), was developed for stream studies relating to dissolved-oxygen and biochemical oxygen demand dynamics.

The mathematical basis of the Pioneer-I model is formulated around concepts of steady-state flow and uses Lagrangian coordinates to determine concentrations of various constituents for a given flow condition, wastesource concentration, water temperature, reaction coefficients, and waterdiversion data. The water-quality dynamics usually are characterized by algorithms of first-order differential equations, although some algorithms of this model have the option for using second-order functions. 
The Pioneer-I model was used in this study by the Colorado Department of Health to compare model results with those obtained with the U.S. Geological Survey model. The Pioneer-I model currently used by the Colorado Department of Health has been further modified with respect to the original Pioneer-I model developed by Battelle Pacific Northwest Laboratories (Waddel and others, 1973) for the U.S. Environmental Protection Agency. The additional modifications to the Pioneer-I model were made by the URS/Ken $R$. White Co. (1975) to facilitate the use of the model in situations where data are scarce. These modifications make it possible to study discrete segments of a river rather than an entire river basin, to add or remove discharges without redefining the entire model, and to allow streamflow in reaches or subreaches of the river to decrease to zero without physically removing these reaches or subreaches from the model input.

The Pioneer-I model recently has been modified again by the Colorado Department of Health to estimate the concentrations of the following constituents: Total nitrogen, dissolved solids, metal ions, orthophosphate, fecal-coliform bacteria, ammonia nitrogen, nitrite nitrogen, nitrate nitrogen, carbonaceous biochemical oxygen demand (CBOD), chlorophy11- $\alpha$, and dissolved oxygen (DO).

\section{DATA USED FOR MODEL CALIBRATION}

\section{Data-Collection Program}

Field data used for calibrating the models were collected at 33 sites along the study reach during 24 hours on September 23-24, 1975. Samples were taken at approximately 3-hour intervals. The basic data collected for this study are tabulated in a report by Giles and Brogden (1977). A total of 16 main-stem, 11 tributary, and 6 wastewater-effluent sites were sampled (table 2 and fig. 6). Only 10 of the 17 tributaries in the study reach were sampled because the remainder had flows of less than $0.1 \mathrm{ft}^{3} / \mathrm{s}\left(0.003 \mathrm{~m}^{3} / \mathrm{s}\right)$. At all sites, field determinations were made for $\mathrm{DO}$, water temperature, specific conductance, fecal-coliform and total-coliform bacteria, and $\mathrm{pH}$. In addition, water samples were collected for laboratory analysis of biochemical oxygen demand (BOD), organic nitrogen (nonfiltered form), ammonia nitrogen, nitriteplus-nitrate nitrogen, Kjeldahl nitrogen, orthophosphate, total phosphorus, and total nitrogen. At least one discharge measurement was made at each sampling site during the 24-hour sampling period.

As stated previously, data for this investigation were collected during a single 24-hour period. As noted by Rickert and Hines (1975), there is an inverse relationship between the complexity of a water-quality process and the ability to produce useful modeling assessments within a given time span. The Yampa River from Steamboat Springs to Hayden is not extremely complicated with respect to the flow regime or water-quality characteristics. Ideally, data for modeling would be collected during different seasons of a year; however, data collected during critical-flow conditions are sufficient to adequately calibrate a model (Hines and others, 1975). Both flow and water-quality characteristics in the study reach normally vary considerably over a yearly cycle. 


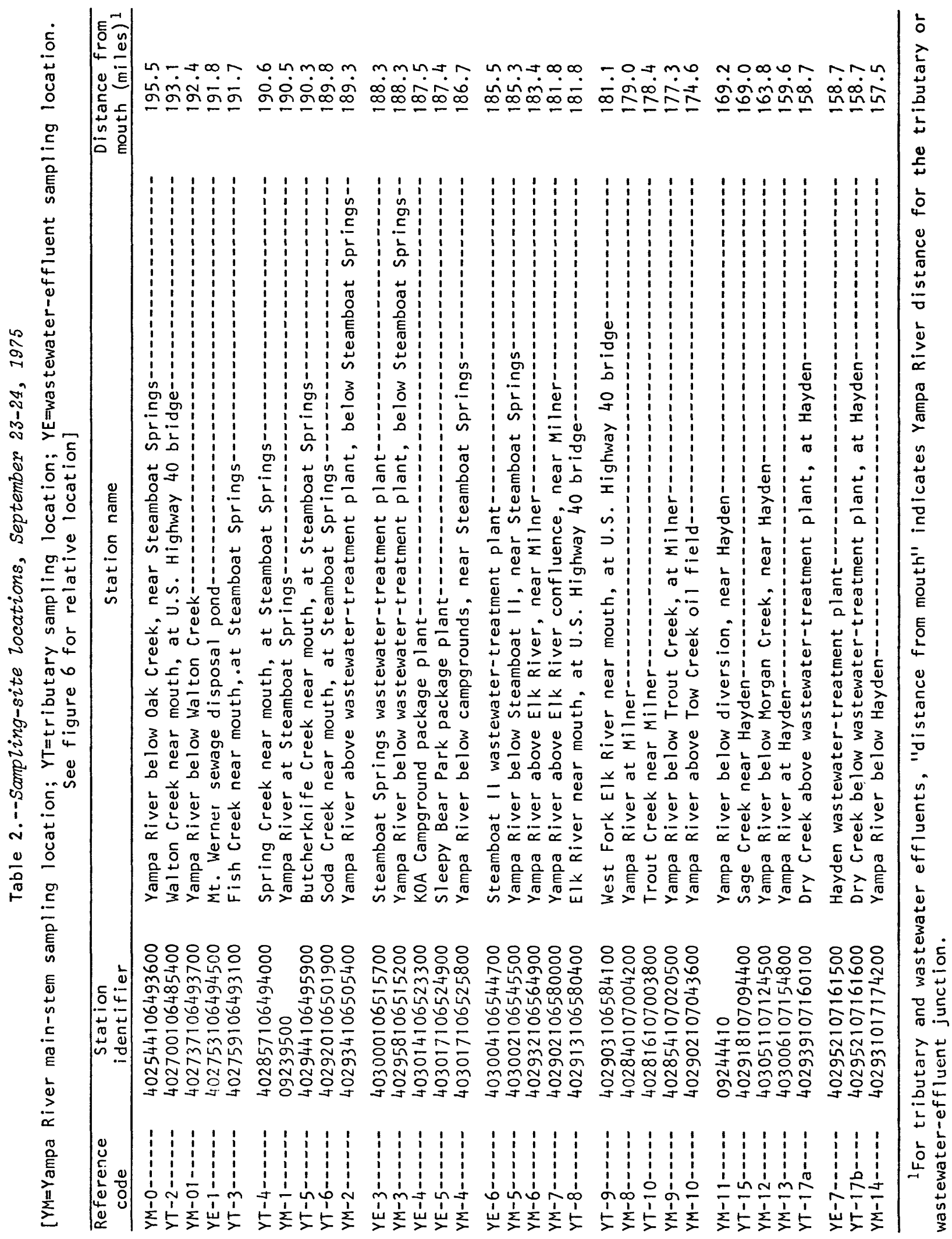


The sampling was done during a 24-hour period to obtain the approximate diel variation for most of the constituents. Only two BOD and nutrient samples were collected at the 11 tributary locations because few diel variations were expected. The main-stem sites YM-9, YM-10, YM-11, YM-12, and YM-13 (fig. 6) are located downstream from the Elk River which contributes approximately 40 percent of the total flow of the Yampa River at the confluence. These sites were sampled only for BOD and nutrients because water from the E1k River was expected to further dilute the wastewater effluent in the Yampa River below the confluence.

A second data-collection effort for a 24-hour period was made during December 1976. Because of the time constraints of this investigation, analysis of these data is not included in this report. The second effort was made to analyze the yearly variability of water-quality and flow characteristics and also to serve as a check of model results during winter (December) conditions.

Steady-state conditions can be assumed for most streams during low flows by dividing a reach into subreaches. Such was the case during the calibration sampling period for the study reach of the Yampa River. To help define depth, velocity, and traveltime data for each subreach of the Yampa River, 15 discharge measurements were made. These measurements were made so that average depth-velocity conditions of the stream in the general vicinity of each measurement could be determined. The discharge of each tributary and wastewater-treatment plant also was measured.

\section{Stream-Reach and Diel Variations}

Profiles of the mean values of DO concentrations, stream temperature, and 5-day $\mathrm{CBOD}\left(\mathrm{CBOD}_{5}\right)$ are shown on figure 7 . This summary is based on data collected during the 24-hour sampling period. The mean Do concentrations in the study reach were within \pm 5 percent of saturation, with the mean Do concentration exceeding $8 \mathrm{mg} / \mathrm{L}$ (milligrams per 1iter) at each location. Mean DO concentrations were larger just upstream and downstream from the main wastewater-treatment plant at Steamboat Springs (sites YM-2 to YM-5, fig. 7 and table 2). These large concentrations may be due, in part, to the large number of algae and submerged vascular plants at the sites. Stream temperatures during the 24-hour sampling period averaged about $10^{\circ}$ to $11^{\circ} \mathrm{C}$ from Steamboat Springs to Sage Creek. Downstream from Sage Creek (downstream from site $Y M-11$ ), the stream temperature in the Yampa River increased to approximately $13^{\circ} \mathrm{C}$. The discharge from Sage Creek (site YT-15), which was receiving thermal-heated effluent from the Hayden Power Plant, had an average temperature of $16^{\circ} \mathrm{C}$ and contributed to the increased temperature in the Yampa River downstream from Sage Creek (sites YM-12, YM-13, and YM-14, fig. 6). The slope of the Yampa River decreases between Sage Creek and Hayden. As a result, the mean river velocity decreases, creating larger pools in this part of the study reach. This results in a longer residence time per unit length of stream and allows the water in the stream to approach its equilibrium temperature more quickly for a given length of stream reach. 


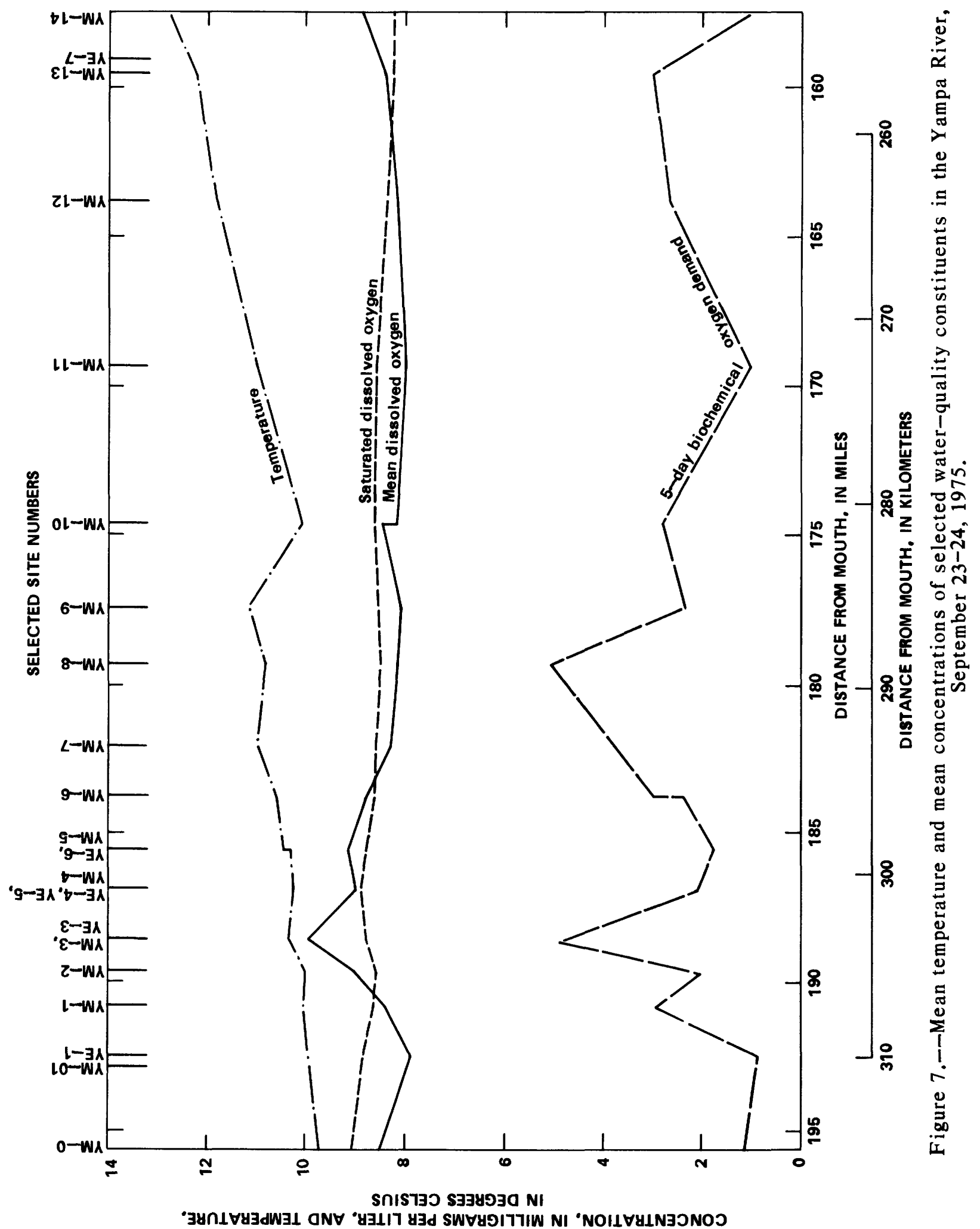


The profile for average concentrations of $\mathrm{CBOD}_{5}$ also is shown on figure 7. Except for a subreach downstream from the main wastewater-treatment plant at Steamboat Springs (site $\mathrm{YE}-3$ ) and another subreach downstream from the Elk River (site YT-9) near Milner, Colo. (table 2), the concentrations of CBOD $_{5}$ are less than $3.0 \mathrm{mg} / \mathrm{L}$. The larger values downstream from Steamboat Springs were expected because of the effects of waste discharges, but the relatively large values downstream from the Elk River are not readily explained. One possible cause of the larger concentrations of $\mathrm{CBOD}_{5}$ downstream from the Elk River is irrigation return flow in this area of the study reach. While the 24-hour survey was being completed, small volumes of return flow in this area were noted, but no samples for analysis of BOD were collected.

The concentrations of total-coliform and fecal-coliform bacteria along the study reach are shown on figure 8. As shown, the higher coliform-bacteria concentrations occur downstream from the Steamboat Springs area where the larger proportion of treated-wastewater effluents discharge into the Yampa River. The two profiles, in general, indicate a gradual die-off of coliform bacteria with increasing distance downstream from Steamboat Springs. The reason for the larger concentration of fecal-coliform bacteria in the vicinity of site YM-12 is not known.

Variations in concentrations of total-coliform and fecal-coliform bacteria for the 24-hour sampling period at site YM-4 are shown on figure 9 . Site YM-4 is located downstream from the effluent discharge of the main wastewatertreatment plant at Steamboat Springs (fig. 6). The large coliform-bacteria concentration at the site is the result of the upstream discharge of wastewater effluents. Concentrations of total-coliform bacteria varied considerably during the 24-hour sampling period; for example, coliform bacteria at site YM-4 (fig. 9) ranged from 380 to 3,500 colonies/100 mL (milliliters) of water.

The diel variations of DO concentrations are shown on figure 10 for sites $\mathrm{YM}-2$, YM-6, and $\mathrm{YM}-11$ (fig. 6 and table 2). A general cyclical pattern is observed at all three sites, with highs during daylight hours typifying photosynthesis in the stream, and with lows at night indicating relative effects of respiration. The largest diel variation ( 7 to $10.5 \mathrm{mg} / \mathrm{L}$ ) occurred at site $\mathrm{YM}-6$, which is located approximately $5 \mathrm{mi}(8 \mathrm{~km})$ downstream from the discharge outlet of the main wastewater-treatment plant at Steamboat Springs. Site YM-2 is located upstream from this outlet. A diel variation of 8.2 to $10.2 \mathrm{mg} / \mathrm{L}$ in DO concentration occurred at site YM-2 during the 24-hour cycle. Data at this site include the effects of the discharge from the wastewaterplant at Mount Werner and any nonpoint sources from Steamboat Springs. Site YM-11 is located upstream from Sage Creek on the Yampa River (fig. 6). A die1 variation of 7.3 to $9.7 \mathrm{mg} / \mathrm{L}$ in DO concentration occurred at this site during the 24-hour cycle. Along the entire length of the study reach, and especially in sections containing pools, varying concentrations of floating and attached plants were observed. In some subreaches, these plant concentrations were larger than in others, with the largest concentrations in the vicinity of Steamboat Springs. 


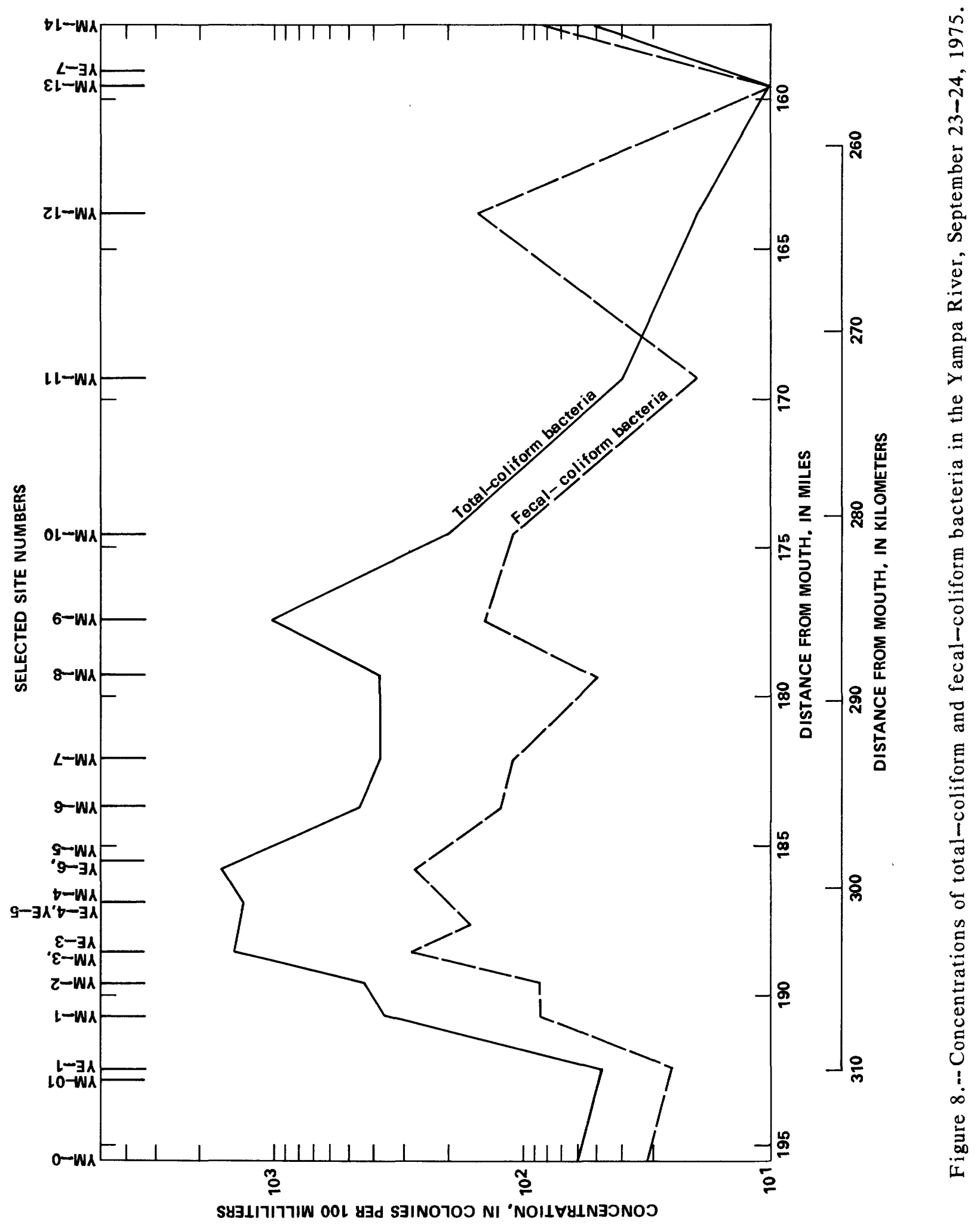




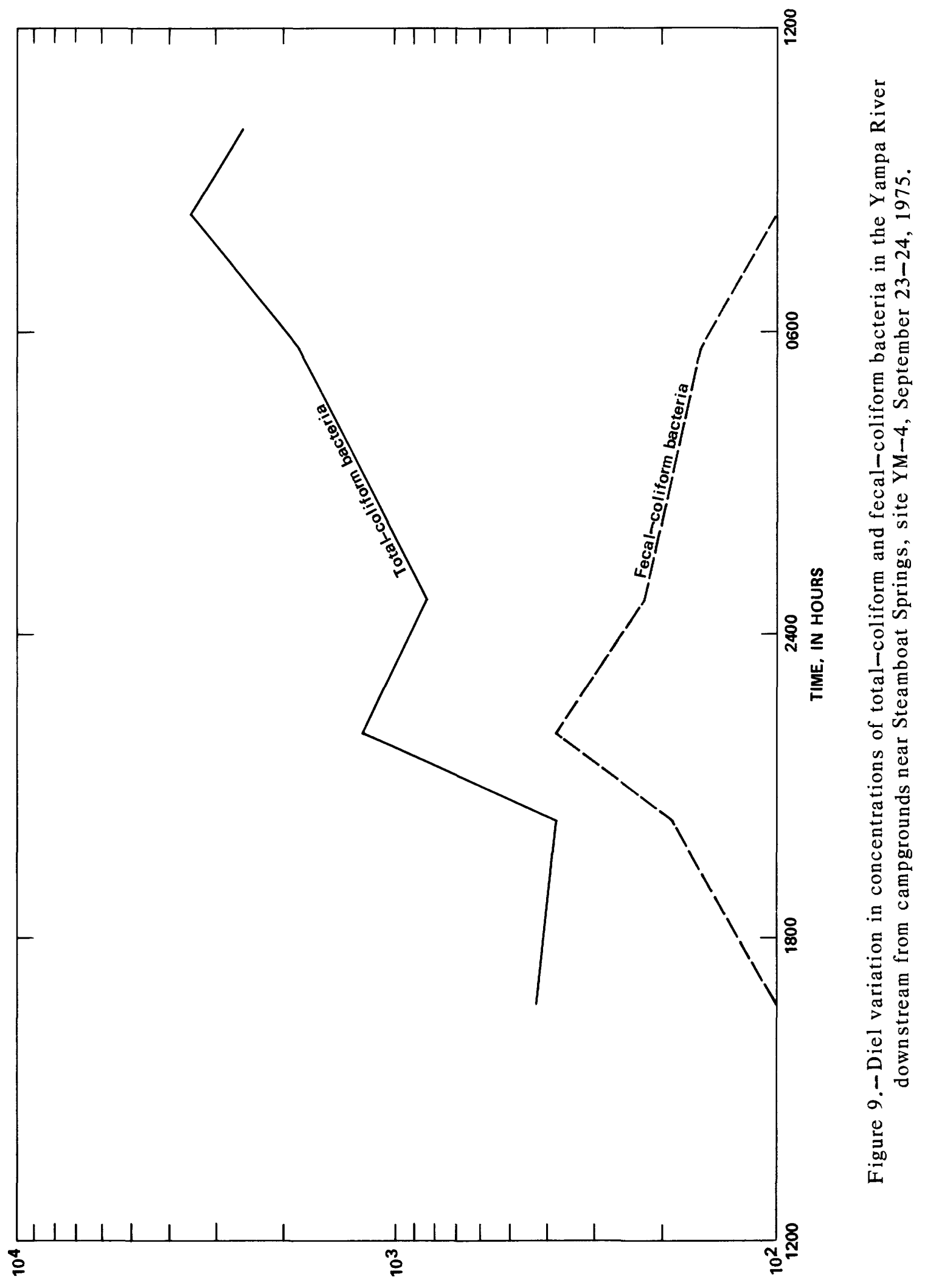

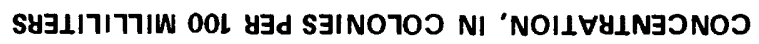




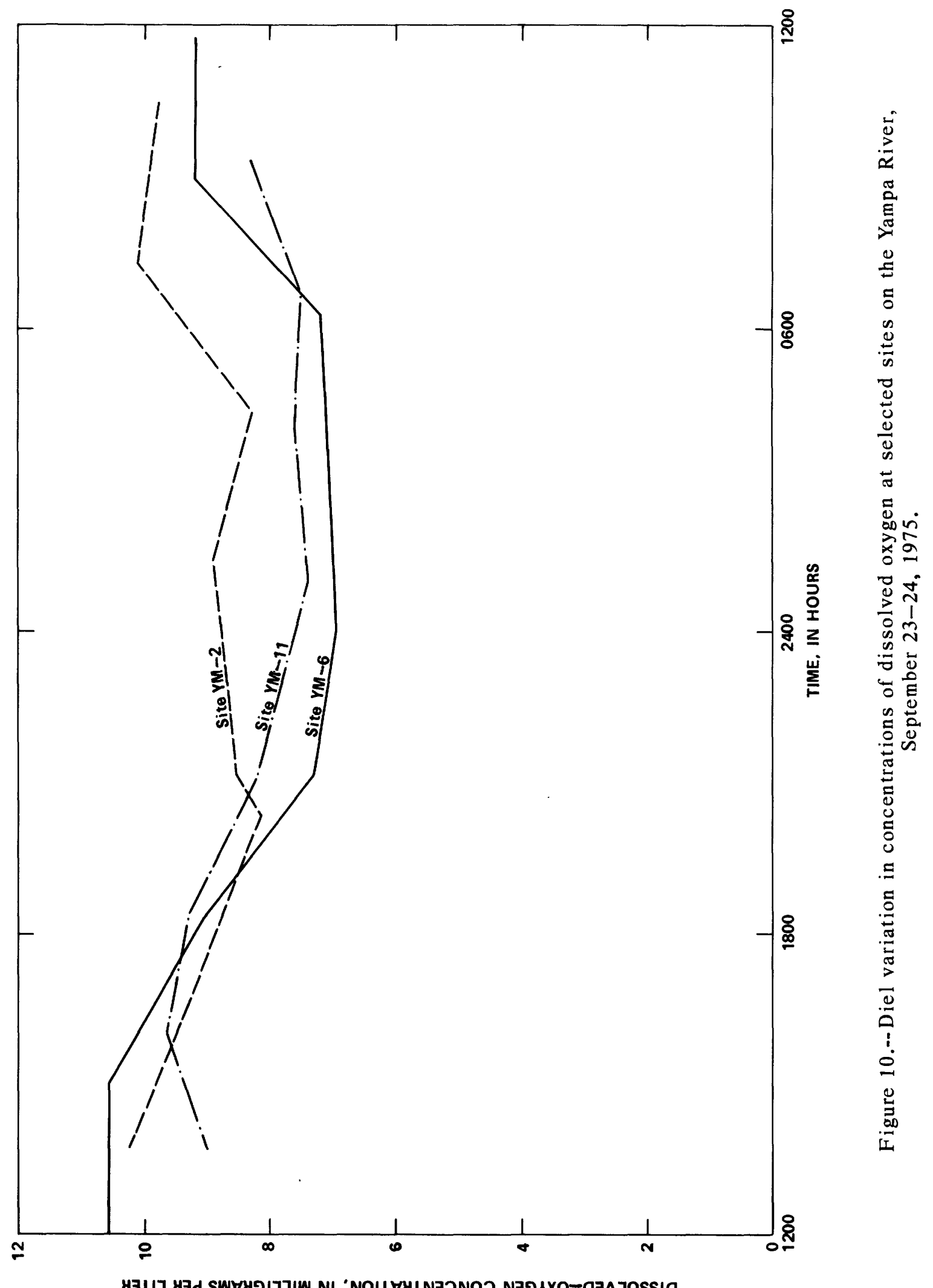

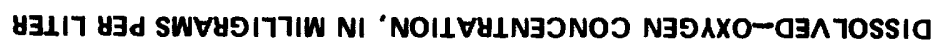




\section{Data-Reduction Techniques}

The CBOD in water samples collected during the 24-hour study on September 23-24, 1975, was analyzed using a procedure described by Hines, McKenzie, Rickert, and Renella (1977). Using this technique, Do concentrations in the sample bottles were measured initially and then remeasured $1,2,3,4,5,6,8,10,12,15$, and 20 days after the initial measurement. These data were analyzed using a computer program developed by Jennings and Bauer (1976). Sample results of this form of analysis are shown on figure 11. By this technique, the ultimate CBOD (CBODU), $\mathrm{CBOD}_{5}$, and decayrate coefficient $\left(K_{1}\right)$ are computed. In the example cited, CBODU $=8.0 \mathrm{mg} / \mathrm{L}$, $\mathrm{CBOD}_{5}=2.9 \mathrm{mg} / \mathrm{L}$, and $K_{1}=0.09$ per day. An average-bottle decay-rate coefficient of about 0.1 per day for the entire study reach was computed using the average of the decay rates determined for the samples.

The decay-rate coefficients for CBOD computed by the decrease in DO in the sample bottles with time are somewhat different from those occurring in a stream environment. A technique described by Velz (1970) was applied to the CBOD data determined in the laboratory for the stream reach downstream from site $\mathrm{YM}-4$, which is $1.6 \mathrm{mi}(2.6 \mathrm{~km})$ downstream from the main wastewatertreatment plant at Steamboat Springs. The stream reach included sites between YM-4 and YM-8. The log of the percentage of CBOD remaining relative to some initial concentration was plotted versus the estimated stream traveltime downstream from the starting point (fig. 12). By manually fitting a straight 1ine through the data points, the arithmetic slope of the line will indicate the approximate decay rate, $K_{1}$, of CBOD in the stream reach. A value of 0.4 per day was determined for $K_{1}$ by visual fit of the data points.

A similar analysis also was made for the coliform-bacteria data. Site YM-4 again was used as the reference site with sites between $Y M-4$ and $Y M-8$ considered. The results of this analysis are shown on figure 13. The die-off rates of coliform bacteria estimated by this visual fitting technique were 0.65 per day for fecal-coliform bacteria and 1.03 per day for total-coliform bacteria.

\section{CALIBRATION RESULTS}

The two water-quality models, U.S. Geological Survey and Pioneer-I, were calibrated using results of the data collected during September 23-24, 1975. In this section the calibration results are discussed and some variations in results of the two models are presented. To provide direct comparison, the same rate coefficients were used in both models.

Water-quality data used in the model calibration included the following variables: CBODU; DO; organic nitrogen, as nitrogen; ammonia nitrogen, as nitrogen; nitrite-plus-nitrate nitrogen, as nitrogen; total nitrogen, as nitrogen; orthophosphate; fecal-coliform bacteria; and total-coliform bacteria. For modeling analysis, the study reach was divided into a number of subreaches defined by the 10 tributaries, diversion sites, discharge points of wastewater-treatment plants, and geometry of the study reach (fig. 6). 


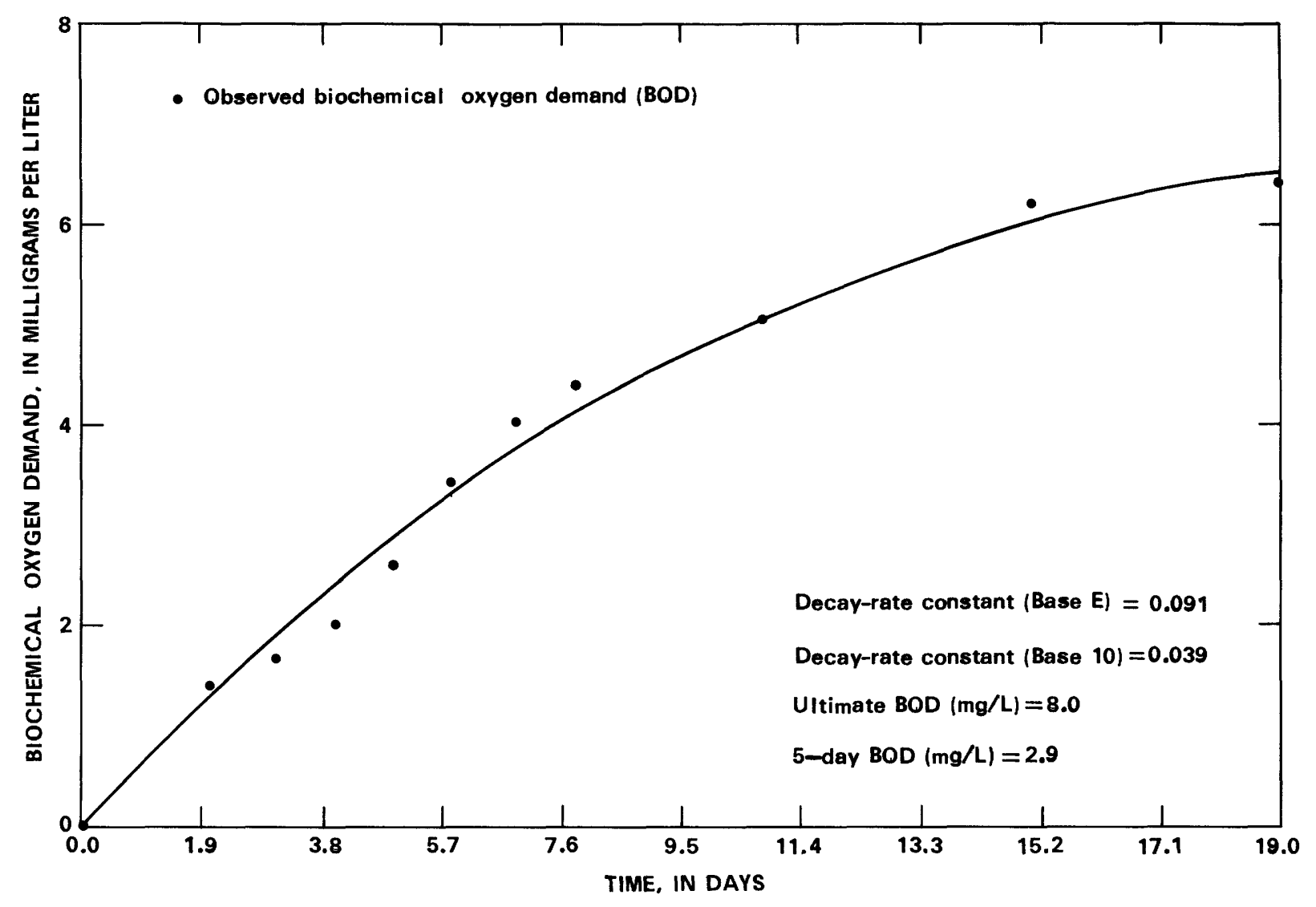

Figure 11.--Least-squares method of calculating decay rates and concentrations of biochemical oxygen demand, Yampa River downstream from Steamboat II near Steamboat Springs, site YM-5. 


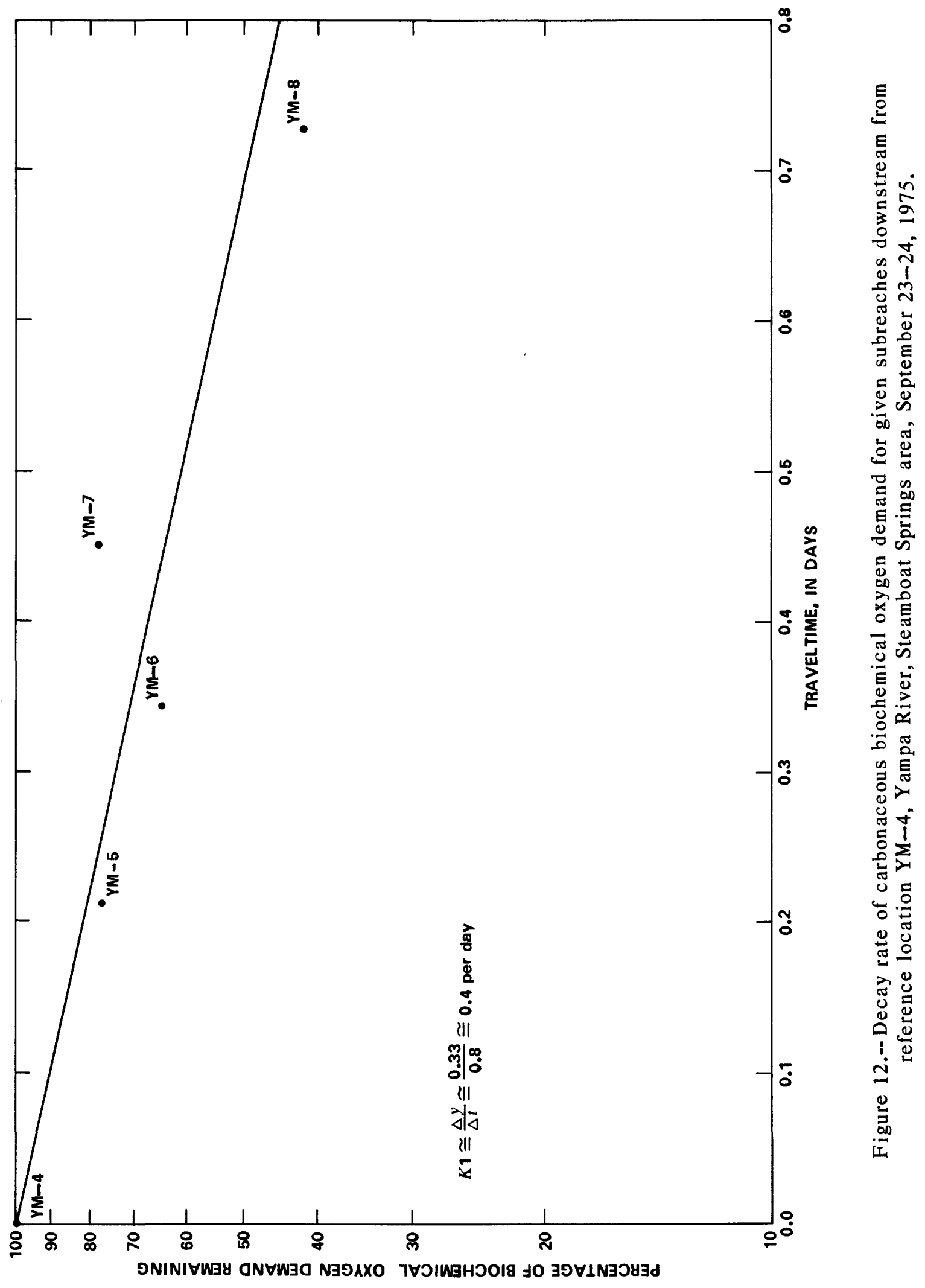




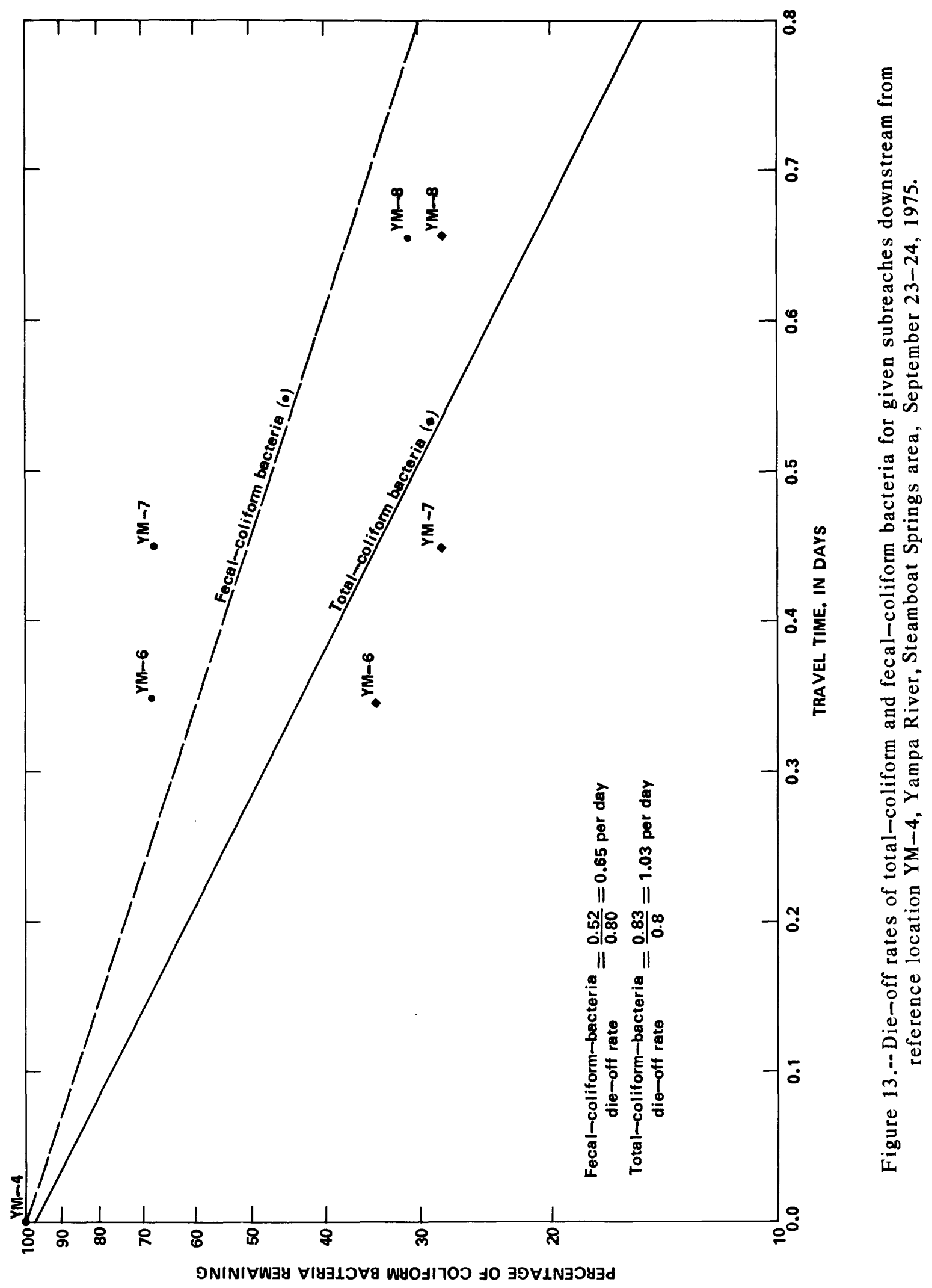


Calibration results indicated nonmixed conditions in the stream cross sections at site YM-3. Visual inspection of this location in October 1975 also indicated nonmixed conditions. Site YM-3 is located approximately $500 \mathrm{ft}$ $(150 \mathrm{~m})$ downstream from the discharge outlet of the main wastewater-treatment plant at Steamboat Springs. The stream at site YM-3 divides into two channels with approximately 75 percent of the flow in the left (southern) channel and 25 percent of the flow in the right (northern) channel. The right channe1, where the samples were collected, receives the largest proportion of the treated-wastewater effluent. Because of this nonmixed condition, all observed data at site YM-3 were adjusted by the approximate flow ratio so that the data could be used in the model-calibration analysis.

Computed versus observed concentrations of CBODU for the study reach are shown on figure 14. The decay-rate coefficient for CBODU used was 0.1 per day for the entire study reach and corresponds to the average-bottle decay-rate coefficient previously computed. Even with using the 0.1-per-day decay-rate coefficient, the computed profile was low compared with the means of the observed data. One explanation could be that some additional BOD loading, such as irrigation return flows, could have affected concentrations of CBODU in the upstream subreaches. The values of CBODU computed by the two models were almost identical for the entire study reach.

The reaeration formula of Bennett and Rathbun (1972) was used in the DO computations. The reaeration formula has the following form:

$$
K_{20}=8.76 V^{0.607 / D^{1.689}}
$$

where

$$
\begin{aligned}
& K_{2}=\text { reaeration-rate coefficient at } 20^{\circ} \mathrm{C} \text {, in } 1 \text { per day; } \\
& V=\text { mean velocity in the river, in feet per second; and } \\
& D=\text { mean depth in the reach, in feet. }
\end{aligned}
$$

This reaeration formula expressed the reaeration-rate coefficient of the stream as a function of mean depth and velocity. The temperature-corrected reaeration-rate coefficients ranged from 3.8 to 13.1 per day with the larger coefficients occurring in the upstream subreaches between sites YM-01 and YM4. The temperature correction of the reaeration-rate coefficient is of the following form:

$$
K_{2}=K_{20}(\sigma)^{T-20}
$$

where

$K_{2}{ }_{T}=$ reaeration-rate coefficient at temperature, $T$, in 1 per day;

$T=$ temperature, in degrees Celsius; and

$(\sigma)=$ empirical constant, set equal to 1.024 for the U.S. Geological Survey and Pioneer-I models. 


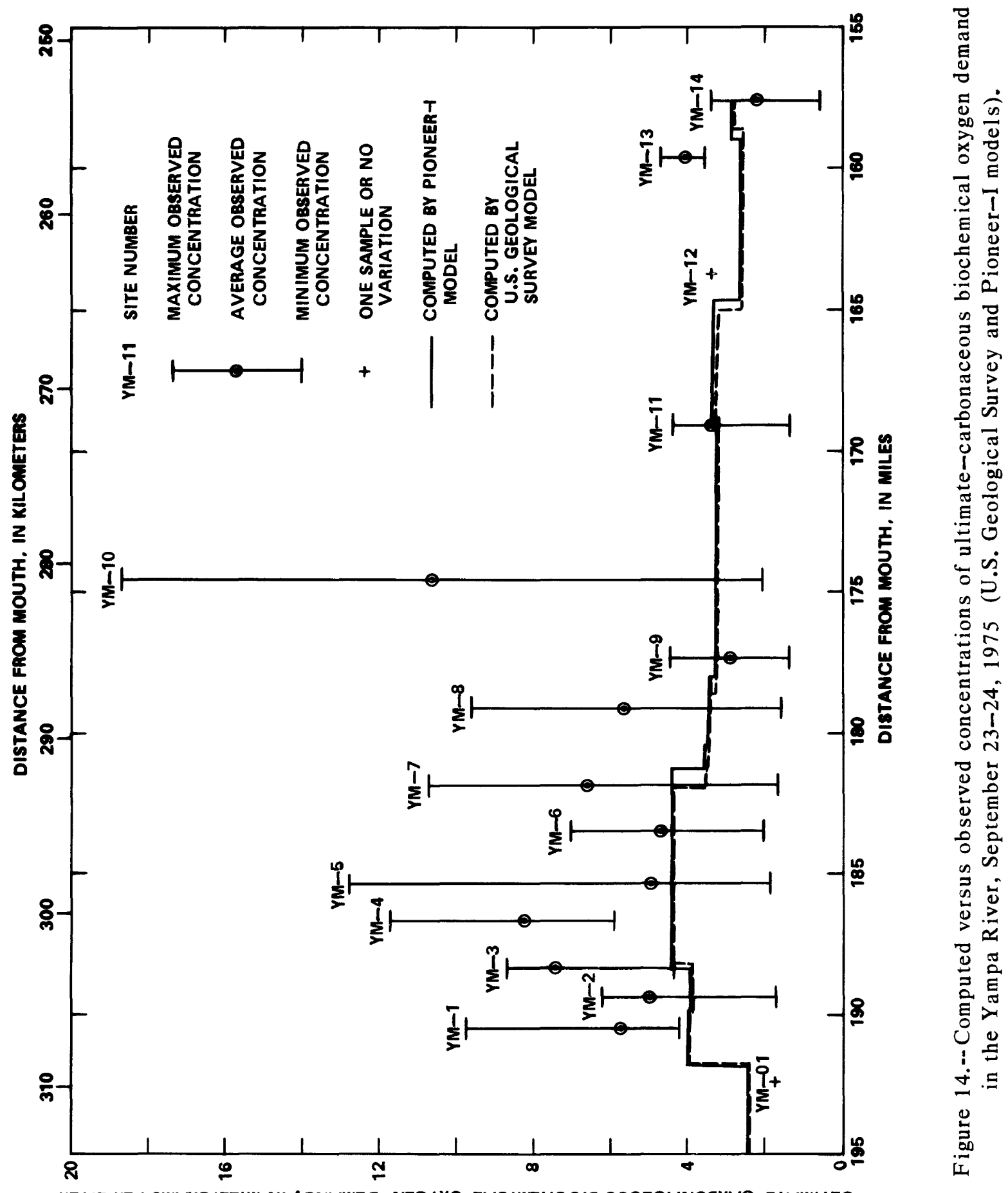


Profiles of computed versus observed Do concentrations are shown on figure 15. The DO profiles computed by the two models are almost identical (fig. 15). To compare the Do concentrations computed by the two models required some consideration to the methods by which the data for mean depth and velocity of the stream are processed by each model. The U.S. Geological Survey model uses mean-depth and velocity data entered into the computer directly in the reaeration-rate computations; whereas, the Pioneer-I model computes the mean depth and velocity using the following equations:

and

$$
V=a Q^{b}
$$

$$
D=a_{1} Q^{b}
$$

where

$$
\begin{aligned}
& Q=\text { mean flow in reach, in cubic feet per second; and } \\
& a, b, a_{1}, b_{1}=\text { regression coefficients. }
\end{aligned}
$$

In the water-quality comparisons, the hydraulic coefficients $a, b, a_{1}$, and $b_{1}$ in equations 3 and 4 for the Pioneer-I model were adjusted until the computed values of mean depth and velocity approximately equaled those used by the U.S. Geological Survey model. In earlier computational comparisons of the two models, somewhat larger differences in the computed Do profiles were due to discrepancies in the traveltime computations in the Pioneer-I model. As indicated by the model computations (fig. 15), the Do sag in the study reach is barely discernible. The computed Do values remained within 95 percent of saturated DO concentrations. Relatively larger diel variations in Do concentrations were observed at several sites, especially in that part of the study reach downstream from the main wastewater-treatment plant at Steamboat Springs (sites $\mathrm{YM}-3$ to $\mathrm{YM}-7$, fig. 15) and downstream from Hayden (site YM-14, fig. 15).

In addition to total nitrogen, the following nitrogen components were modeled: Organic nitrogen (nonfiltered form), ammonia nitrogen, and nitriteplus-nitrate nitrogen. The temperature-corrected rate coefficients using first-order exponential decay algorithms from the model calibrations were organic nitrogen, 0.2 per day; ammonia nitrogen, 0.3 per day; nitrite nitrogen, 1.0 per day; and nitrate nitrogen, 1.7 per day. Each nitrogen-rate coefficient was corrected for water-temperature variation by an empirical coefficient of 1.047 using an expression similar to equation 2. The rate coefficient of 1.7 per day for nitrate nitrogen applies only to the U.S. Geological Survey model. The Pioneer-I model accumulates the nitrate nitrogen as the final step in its nitrogen-cycle computations.

The model-calibration results give estimates for nitrite and nitrate concentrations separately. These values then were added together and compared to the observed data. Total nitrogen, which was treated in both models as a conservative constituent, was modeled to provide some indication of where the nitrogen was being used or supplied in the study reach other than from point sources. 


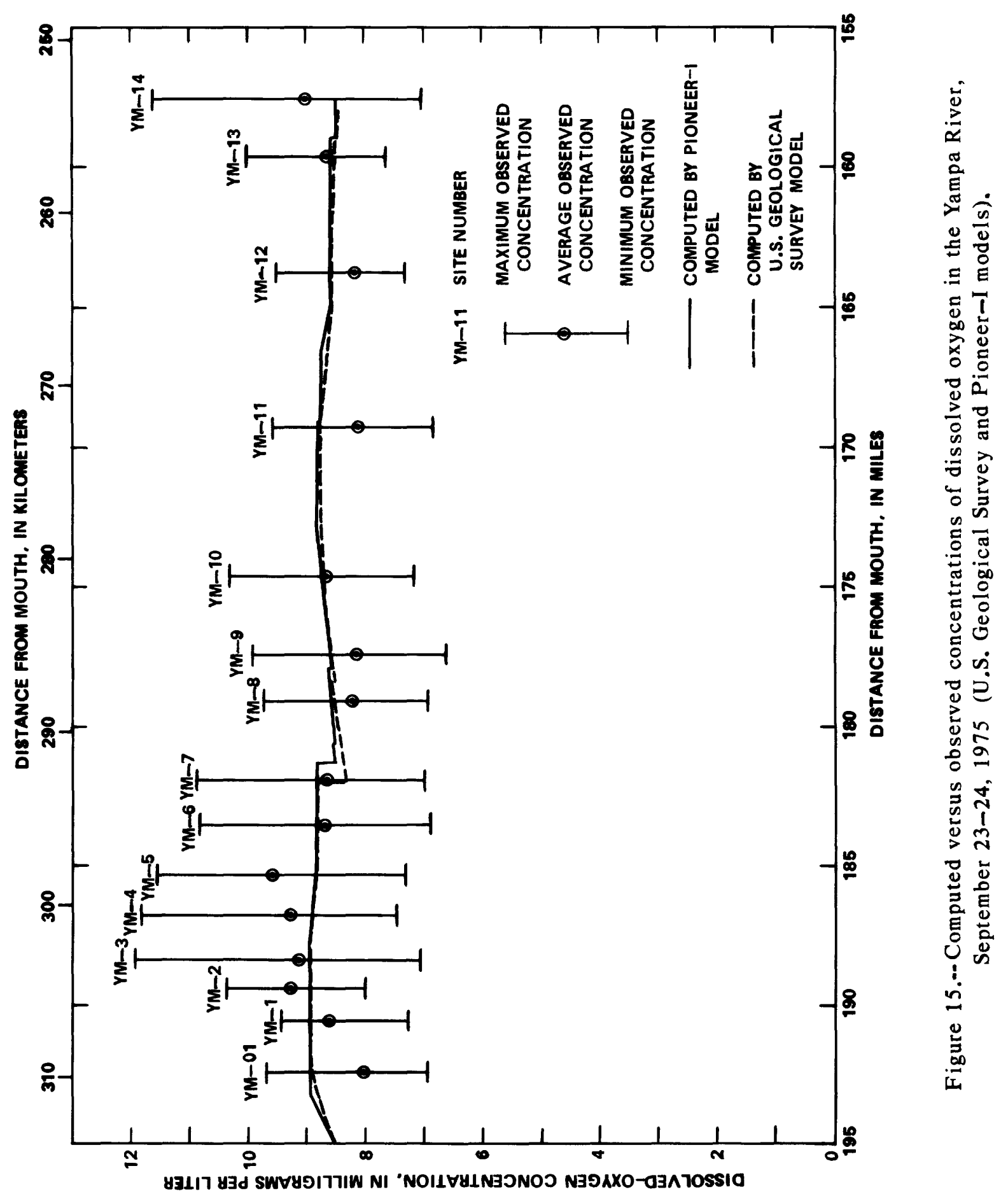


The profiles of computed organic-nitrogen concentrations (fig. 16) fit the average observed organic nitrogen within data and model accuracies. The computed ammonia-nitrogen concentrations (fig. 17) are larger than the observed concentrations except at site $\mathrm{YM}-3$. The rapid disappearance of ammonia downstream from site $\mathrm{YM}-3$ is a phenomenon observed on al1 Colorado streams surveyed by the Colorado Department of Health (R. D. Anderson, written commun., 1976). The computed profiles of concentrations of nitrite-plusnitrate nitrogen (fig. 18) from sites YM-0 to YM-5 agree within 20 percent of the observed values, but downstream from site YM-5 the computed values were consistently larger than observed values. Computed versus observed tota1nitrogen concentrations are shown on figure 19. Observed concentrations were 20 to 40 percent smaller than concentrations computed by both models downstream from site $\mathrm{YM}-8$.

The comparison of the results of computed concentrations of organic nitrogen, ammonia nitrogen, nitrite nitrogen, and nitrate nitrogen agree closely for the U.S. Geological Survey and Pioneer-I models from approximately site YM-01 to site YM-8. For the reach downstream from site YM-8, some variations in the computed values are noted. The larger computed concentrations of nitrite-plus-nitrate nitrogen for the Pioneer-I model can be explained by its accumulation of nitrogen in the nitrate form. The reason for the differences in computed organic-nitrogen and ammonia-nitrogen concentrations between the two models is not known. Some additional tests need to be made with each model to determine reasons for these differences. Computed total nitrogen, which was modeled as a conservative constituent, agreed closely between the two models along the entire study reach (fig. 19).

There are several possible explanations of the poor fit of computed versus observed ammonia nitrogen (fig. 17). Willingham (1976) reported that ammonia nitrogen in aqueous solutions exists in two states, ionized $\mathrm{NH}_{4}^{+}$and nonionized $\mathrm{NH}_{3}$. In its nonionized $\left(\mathrm{NH}_{3}\right)$ state, ammonia can escape as a gas from water. According to Willingham (1976), the partitioning of total ammonia between nonionized $\mathrm{NH}_{3}$ or $\mathrm{NH}_{4}^{+}$forms is dependent primarily on $\mathrm{pH}$ and temperature conditions. The estimated ranges of ammonia as $\mathrm{NH}_{3}$ during the 24hour sampling period are shown in table 3. The percentage of nonionized $\mathrm{NH}_{3}$ in most instances is less than 15 percent, which suggests that the loss of nitrogen as gaseous ammonia to the atmosphere is small. A second explanation is the use of the ammonia nitrogen by plants in the stream environment, for example, by the different algal forms. Kittrell (1969) reported that ammonia nitrogen can be assimilated by algae and changed to organic nitrogen by algae. It was noted that DO is not utilized in this process. Kittrell also pointed out that organic nitrogen, changed to ammonia nitrogen and oxidized to nitrate nitrogen, can be assimilated quickly by algae, which reconvert the nitrogen to protein as an organic-nitrogen form. Dissolved oxygen is used in this latter process. Because of the small oxygen sag in any part of the study reach (fig. 15), it is assumed for the Yampa River that nitrogen most probably is being lost as ammonia. The amount of DO used by the oxidation of organic and ammonia nitrogen to nitrate nitrogen is accounted for by both models, with a rate of 4.57 units of DO for each unit of nitrogen oxidized. 


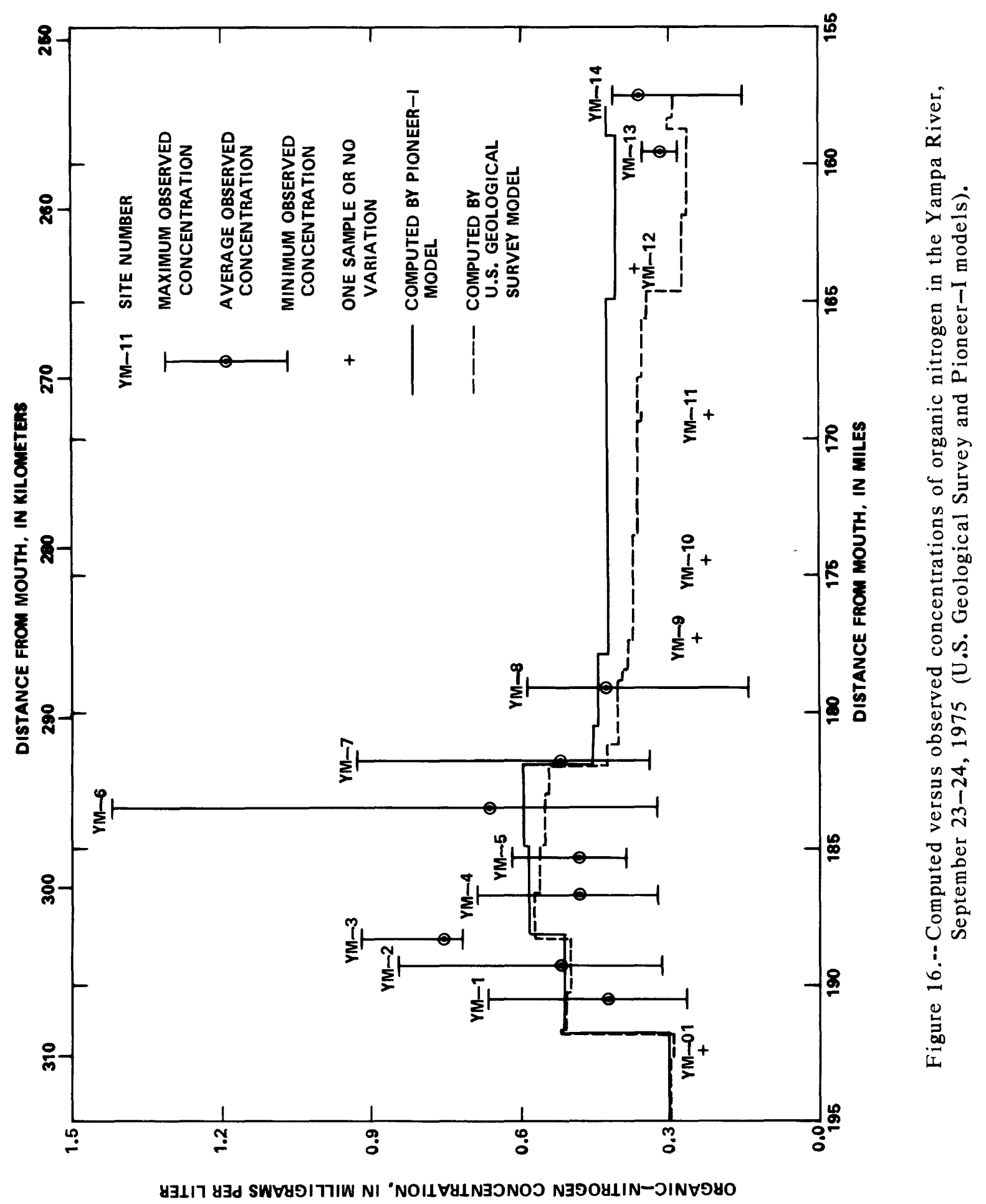




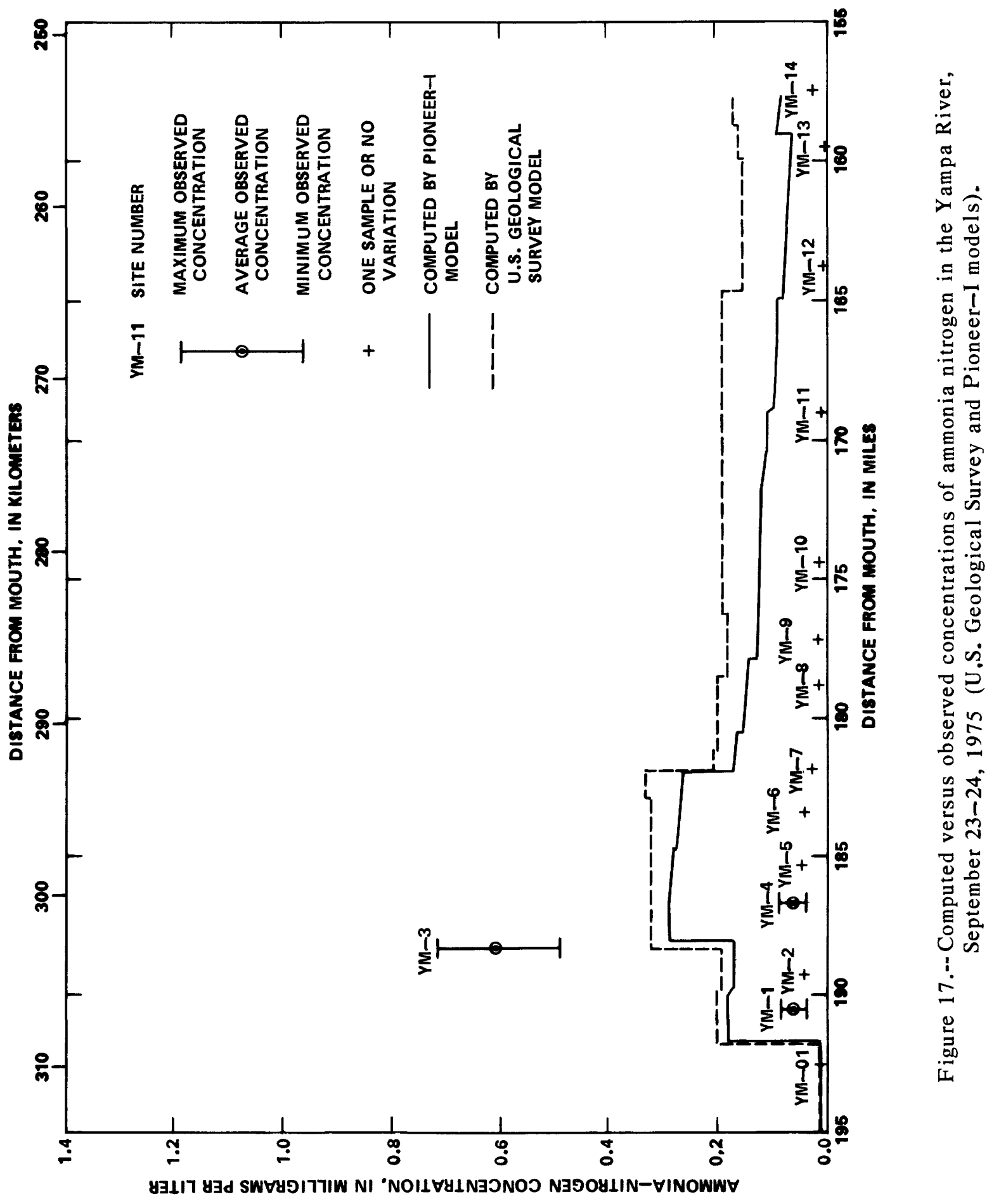




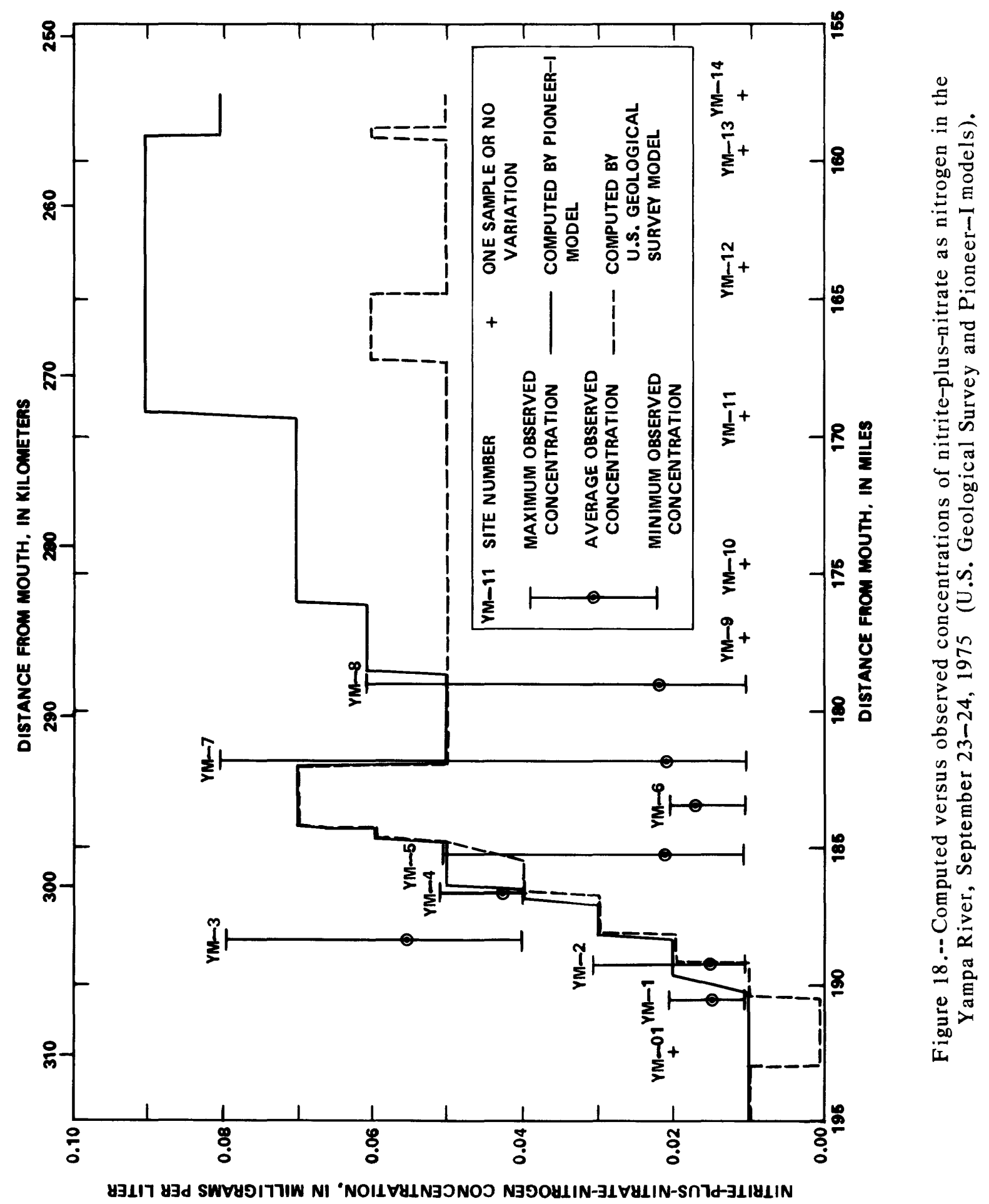




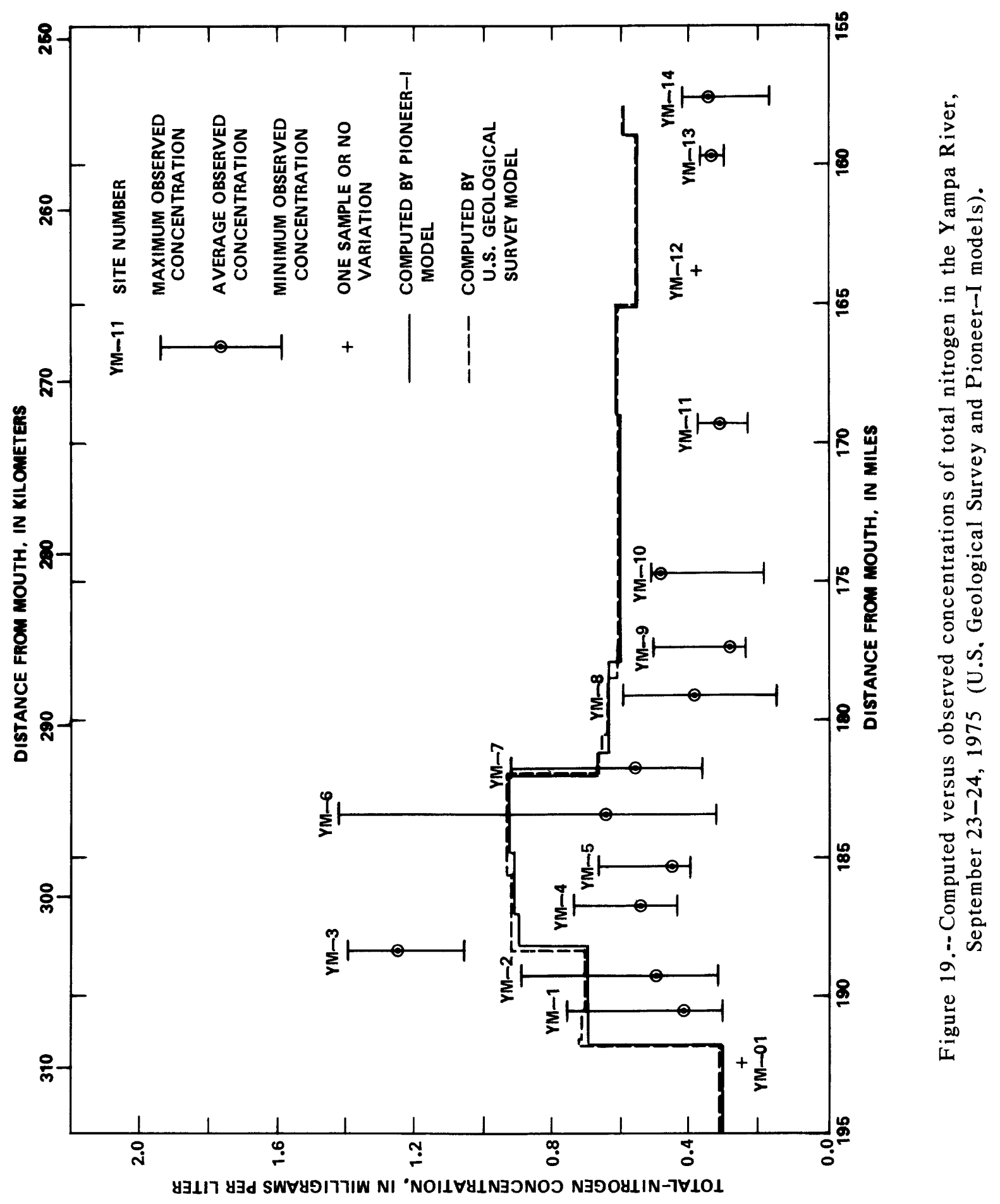


Table 3.--Nonionized ammonia $\left(\mathrm{NH}_{3}\right)$ for observed $\mathrm{pH}$ and temperature values, Yompa River, September 23-24, 1975

\begin{tabular}{|c|c|c|c|c|}
\hline Location 1 & $\begin{array}{c}\text { Average } \\
\text { temperature, } \\
\text { in degrees } \\
\text { Celsius }\end{array}$ & $\begin{array}{l}\mathrm{pH} \\
\text { range }\end{array}$ & $\begin{array}{c}\mathrm{pH} \\
\text { median }\end{array}$ & $\begin{array}{l}\mathrm{NH}_{3} \text { range } \\
\text { (percentage } \\
\text { of total } \\
\text { ammonia) }\end{array}$ \\
\hline $\begin{array}{l}\text { YM-0 } 0 \\
\text { YM-01 } \\
\text { YM-1 } \\
\text { YM-2 } \\
\text { YM-3 }\end{array}$ & $\begin{array}{l}10 \\
10 \\
10 \\
10 \\
10\end{array}$ & $\begin{array}{l}8.4-8.7 \\
8.3-8.8 \\
8.3-9.0 \\
7.1-8.1 \\
7.2-8.7\end{array}$ & $\begin{array}{l}8.6 \\
8.5 \\
8.6 \\
7.8 \\
7.8\end{array}$ & $\begin{array}{r}4.5-8.5 \\
3.6-10.5 \\
3.6-15.7 \\
.2-2.3 \\
.3-8.5\end{array}$ \\
\hline 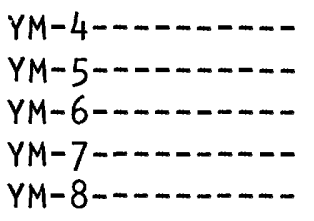 & $\begin{array}{l}10 \\
10 \\
11 \\
11 \\
11\end{array}$ & $\begin{array}{l}7.2-8.9 \\
7.5-8.9 \\
8.2-9.1 \\
7.8-9.0 \\
8.0-9.0\end{array}$ & $\begin{array}{l}8.1 \\
8.2 \\
8.7 \\
8.2 \\
8.2\end{array}$ & $\begin{array}{r}.3-12.9 \\
.6-12.9 \\
3.1-20.2 \\
1.3-16.7 \\
2.0-16.7\end{array}$ \\
\hline $\begin{array}{l}Y M-9 \\
Y M-10 \\
Y M-11 \\
Y M-12 \\
Y M-13 \\
Y M-14\end{array}$ & $\begin{array}{l}11 \\
11 \\
11 \\
12 \\
12 \\
12\end{array}$ & $\begin{array}{l}7.9-8.7 \\
7.9-8.5 \\
7.9-8.6 \\
7.3-8.4 \\
7.4-8.4 \\
7.0-8.8\end{array}$ & $\begin{array}{l}8.1 \\
8.3 \\
8.1 \\
7.5 \\
7.7 \\
8.2\end{array}$ & $\begin{array}{l}1.6-9.1 \\
1.6-6.0 \\
1.6-7.4 \\
.4-5.2 \\
.5-5.2 \\
.2-12.0\end{array}$ \\
\hline
\end{tabular}

${ }^{1}$ See figure 6.

In the nitrogen-cycle fitting process by both models, it was the intent to fit the nitrite-plus-nitrate nitrogen and organic nitrogen more closely than the ammonia nitrogen. This was decided upon because there was no possible means to fit the observed ammonia-nitrogen profile with a first-order decay function with the models being used. As was noted earlier, the comparison between computed versus observed nitrite-plus-nitrate nitrogen and organic-nitrogen concentrations in the upstream subreaches of the Yampa River from sites YM-01 to $Y M-5$ was thought to be adequate. Because the ammonia nitrogen is part of the nitrogen cycle, this procedure results in conservative estimates of ammonia-nitrogen concentrations.

A comparison of observed and computed orthophosphate concentrations is shown on figure 20. This constituent represents another critical nutrient for the plant community in the stream system. The orthophosphate-concentration profiles computed by the U.S. Geological Survey and Pioneer-I models differ more in the downstream part of the study reach. Both models appear to compute higher values than the observed average or single values. The orthophosphateconcentration profiles were computed assuming phosphorus to be a nonconservative substance and neglected the effects of nonconservative organic inputs of phosphorus. The orthophosphate computations of both models use two 


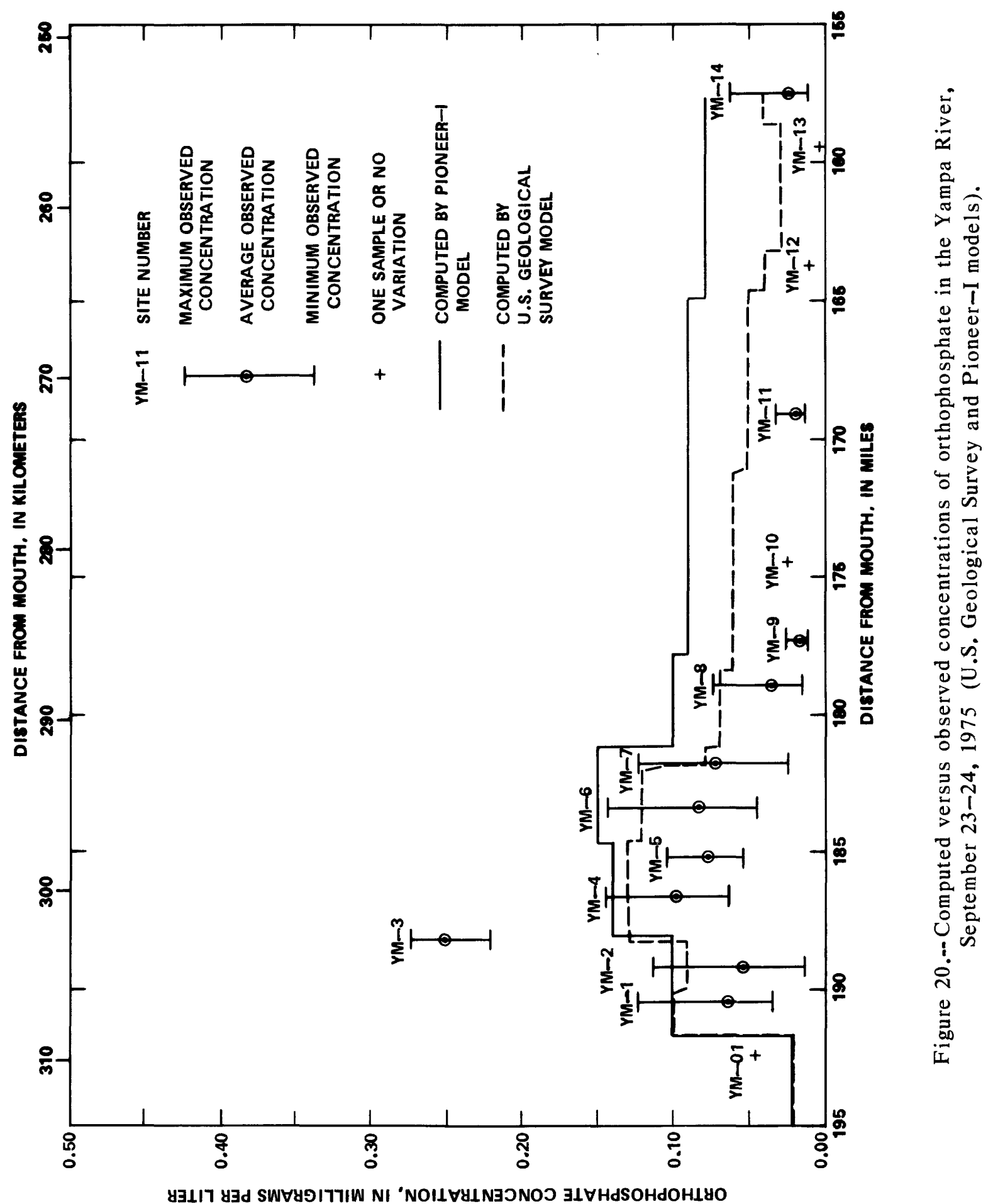


first-order decay coefficients, as described by Willis, Anderson, and Dracup (1975). The first coefficient relates phosphorus losses to benthos, and the second coefficient relates phosphorus use to chlorophyl1- $\alpha$. The temperaturecorrected rate coefficients used in the models were 0.45 per day and 0.0 per day for the first and second orthophosphate-decay rates, respectively. The second coefficient relating to chloryphyl1-a use was found to have little effect for the model calibrations and therefore was neglected.

The calibration results of the fecal-coliform and total-coliform bacteria are shown on figures 21 and 22, respectively. Considering the accuracy of the coliform-bacteria determinations and the range of observed diel variations (fig. 9), the modeling results give a general idea of profile variations. The results from the two models for the fecal-coliform bacteria were nearly identical (fig. 21). No comparison was made for the total-coliform bacteria because the Pioneer-I model did not include an algorithm for its computation.

One purpose of the model-calibration analysis was to evaluate the various computational algorithms in the models. A second purpose was to derive a unique set of model-parameter values. As shown in the preceding discussion of calibration results, some differences in the computed profiles were noted. The large scatter of the observed field data makes it difficult to derive the unique set of model parameters in the calibration phase for either model. As a result, calibration results are considered only fair. For the simulation phase of the analysis, described later, only the U.S. Geological Survey model was used. This choice was made because of previous experience with the model, the ease with which it can be used, and the form of required input data.

\section{FACTORS INCORPORATED INTO MODEL SIMULATIONS}

\section{Existing Stream-Reach Classification}

The study reach of the Yampa River, from Steamboat Springs to Hayden, has been classified as a cold-water-fishery secondary-body-contact type Bl (Colorado Department of Health, 1974). Stream-quality requirements for this classification include the following: Do concentrations to equal or exceed 6 $\mathrm{mg} / \mathrm{L}$, concentrations of fecal-coliform bacteria to be less than 1,000 colonies/100 mL, a pH range from 6.0 to 9.0 , water temperature not to exceed $20^{\circ} \mathrm{C}$, the maximum temperature increase from ambient water temperature not to exceed $1.1^{\circ} \mathrm{C}$, and a recommended requirement that nonionized ammonia concentrations be less than or equal to $0.02 \mathrm{mg} / \mathrm{L}$ (Colorado Department of Health, written commun., 1976; U.S. Environmental Protection Agency, 1976). Other variables considered in the standards of the State of Colorado and U.S. Environmental Protection Agency, such as taste, odor, color, and solids, are not included in this analysis.

The nonionized ammonia concentrations are not computed directly by the U.S. Geological Survey or Pioneer-1 models; instead, they are computed manually using reference tables. For the simulation phase of this study, tables in a report by Willingham (1976) were used. These tables express the 


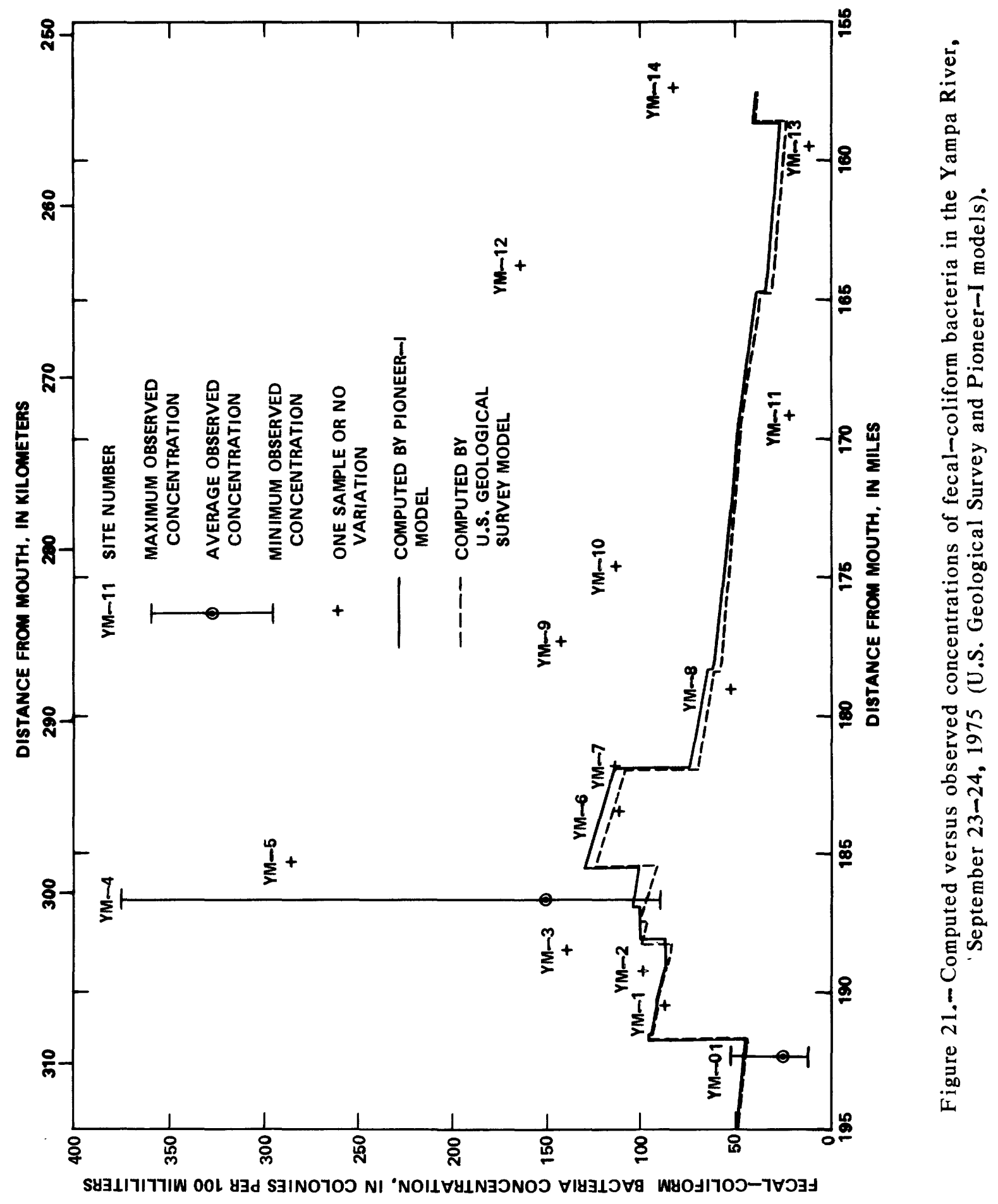




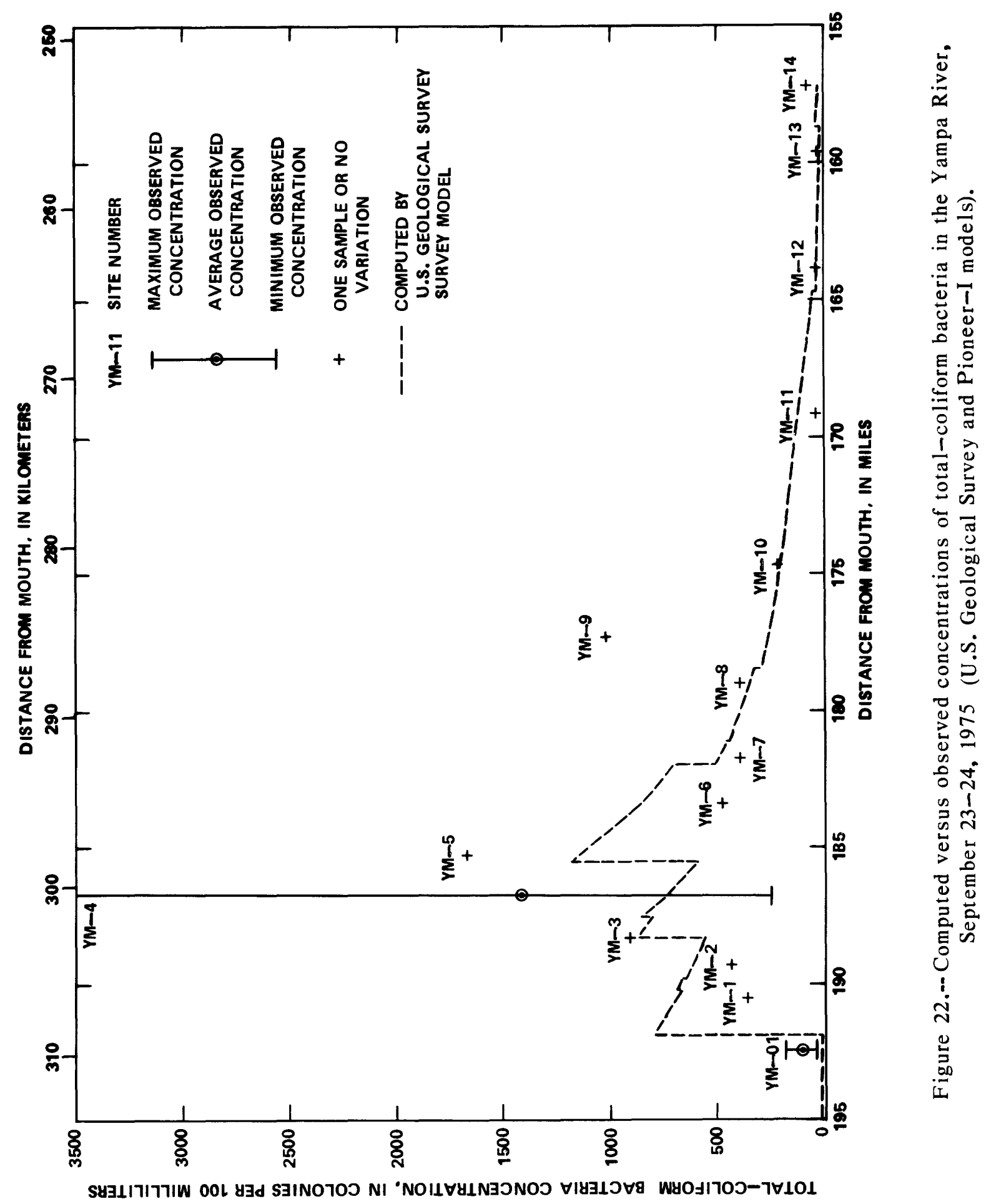


nonionized ammonia nitrogen as a percentage of the ammonia-nitrogen concentration based on the water temperature and $\mathrm{pH}$. A short summary of some of the nonionized ammonia-nitrogen concentrations from Willingham (1976) for a range of $\mathrm{pH}$ from 6 to 9 , and a range of water temperature from $0^{\circ}$ to $15^{\circ} \mathrm{C}$ is presented in table 4. It is noted that the percentage of nonionized ammonia nitrogen increases significantly with increases in $\mathrm{pH}$ with an approximate threefold change for each one-half unit change in $\mathrm{pH}$ for a constant water temperature. Studies by Skarheim (1973) also have shown the nonionized ammonia nitrogen as a function of total dissolved solids. Because water in the study reach does not contain more than 200 to $300 \mathrm{mg} / \mathrm{L}$ total dissolved solids (Wentz and Steele, 1976), the effect of total dissolved solids was not considered in the simulation phase of the analysis.

Table 4.--Percentage of nonionized ammonia nitrogen in ammonia-water solutions at various $p H$ and water-temperature values [After Willingham, 1976]

\begin{tabular}{|c|c|c|c|c|c|c|}
\hline \multirow{2}{*}{$\begin{array}{c}\mathrm{pH} \\
\text { (units) }\end{array}$} & \multicolumn{6}{|c|}{ Water temperature, in } \\
\hline & 0 & 3 & 6 & 9 & 12 & 15 \\
\hline $\begin{array}{l}9.0 \\
8.5 \\
8.0 \\
7.5\end{array}$ & $\begin{array}{r}7.64 \\
2.55 \\
.820 \\
.261\end{array}$ & $\begin{array}{l}9.60 \\
3.25 \\
1.05 \\
.335\end{array}$ & $\begin{array}{l}11.9 \\
4.11 \\
1.33 \\
.427\end{array}$ & $\begin{array}{r}14.7 \\
5.16 \\
1.69 \\
.542\end{array}$ & $\begin{array}{r}17.9 \\
6.44 \\
2.13 \\
.68\end{array}$ & $\begin{array}{r}21.5 \\
7.97 \\
2.67 \\
.859\end{array}$ \\
\hline $\begin{array}{l}7.0 \\
6.5 \\
6.0\end{array}$ & $\begin{array}{l}.083 \\
.026 \\
.008\end{array}$ & $\begin{array}{l}.106 \\
.034 \\
.011\end{array}$ & $\begin{array}{r}.135 \\
.043 \\
.014\end{array}$ & $\begin{array}{l}.172 \\
.054 \\
.017\end{array}$ & $\begin{array}{l}.217 \\
.069 \\
.022\end{array}$ & $\begin{array}{l}.273 \\
.086 \\
.027\end{array}$ \\
\hline
\end{tabular}

Effluent Standards of Proposed Regional Wastewater-Treatment Plant

A regional wastewater-treatment plant is proposed in the Steamboat Springs area and is discussed in a wastewater-facilities plan (U.S. Environmental Protection Agency, 1977). The proposed regional plant would replace existing wastewater-treatment plants at Mount Werner, Steamboat Springs, the KOA campground, Sleepy Bear Trailer Park, and the Steamboat-II development (table 1).

As part of the wastewater-facilities plan for Steamboat Springs, four alternative treatment-plant proposals are discussed (U.S. Environmental Protection Agency, 1977). The alternatives are as follows:

1. Site in Steamboat Springs using extended aeration in lagoons and advanced biological treatment. 
2. Site in Steamboat Springs using extended aeration in lagoons and advanced wastewater treatment.

3. Midway regional site using extended aeration in lagoons and advanced biological treatment.

4. Midway regional site using mixed advanced wastewater treatment.

The physical location of the facilities involved in alternatives 1 and 2 would be in the vicinity of the existing main wastewater-treatment plant at Steamboat Springs. The proposed location of the facilities involved in alternatives 3 and 4 is approximately $2 \mathrm{mi}(3.2 \mathrm{~km})$ downstream from the existing treatment plant at Steamboat Springs and $0.25 \mathrm{mi}(0.40 \mathrm{~km})$ upstream from the Steamboat-II development. Alternatives 1 and 3 would involve complete year-round plant treatment; whereas, alternatives 2 and 4 would involve land treatment during the summer months and biological treatment in the winter months. This report will consider only alternative 1 . Land treatment, incorporated in alternatives 2 and 4 , could produce nonpoint-source runoff, which this study framework has no means to evaluate. Alternative 3 would result in virtually the same analysis as alternative 1 displaced by the distance between the proposed locations. The suggested standards for certain constituents in the effluent to be discharged from the proposed wastewatertreatment plant (U.S. Environmental Protection Agency, 1977) would be upgraded with time, as indicated in table 5. These proposed limitations on the concentrations of constituents in the effluent were considered in the analysis and will be discussed later in this report. Because the suggested standards for 1978 and 1983 are the same, only one simulation for 1978 was done in the analysis. The results presented also apply to 1983 .

\section{Table 5.--Suggested effluent standards for proposed} regional wastewater-treatment plant

[U.S. Environmental Protection Agency, 1977; units are in milligrams per liter]

\begin{tabular}{|c|c|c|c|}
\hline \multirow{2}{*}{ Constituent } & \multicolumn{3}{|c|}{ Year } \\
\hline & 1978 & 1983 & 1985 \\
\hline BOD (5-day) $-\cdots$ & 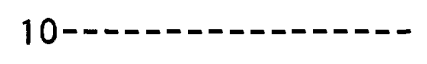 & 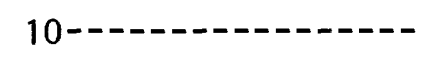 & 5.0 \\
\hline Total N-D. & $10-\cdots+-1-\cdots$ & $10-\cdots+-\cdots$ & 5.0 \\
\hline Ammonia $\mathrm{N}^{1}$ & $\begin{array}{l}2.8 \text { (September) }- \\
9.0 \text { (December) }\end{array}$ & $\begin{array}{r}2.8 \text { (September) }--- \\
<9.0 \text { (December) }-\cdots\end{array}$ & $\begin{array}{l}1.0 \\
1.0\end{array}$ \\
\hline Nitrate--n- & 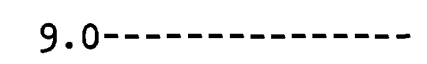 & 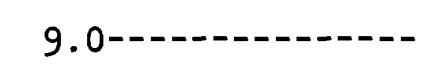 & $<4.5$ \\
\hline DO- - - - - - - & $6.0-1-1-1-n-1$ & $6.0-\cdots$ & 6.0 \\
\hline
\end{tabular}

${ }^{1}$ Al lowable stream loading (1978 and 1983) of ammonia nitrogen varies over yearly cycle. Two values are shown for 2 months used in the modeling analysis. 
The Upper Yampa Water Conservancy District and the Colorado Water Conservation Board have proposed the construction of the Yamcolo Reservoir on the Bear River, a tributary of the Yampa River, in Garfield County (fig. 1). An engineering feasibility and operational study of the proposed reservoir was conducted by Western Engineers, Inc. (1975). Of particular interest to the analysis of waste-load assimilative capacity is the possibility of streamflow augmentation from the Yamcolo Reservoir in the study reach of the Yampa River. The operating rules of the proposed reservoir would include possible augmentation of flow in the Yampa River by approximately $20 \mathrm{ft}^{3} / \mathrm{s}\left(0.6 \mathrm{~m}^{3} / \mathrm{s}\right) \mathrm{during}$ low-flow periods. On the basis of streamflow-data evaluation for the State of Colorado (Livingston, 1970), the computed Q7,10 flow of the Yampa River at Steamboat Springs was $28 \mathrm{ft}^{3} / \mathrm{s}\left(0.78 \mathrm{~m}^{3} / \mathrm{s}\right)$ with a standard deviation of 27 $\mathrm{ft}^{3} / \mathrm{s}\left(0.76 \mathrm{~m}^{3} / \mathrm{s}\right)$ and a standard error of 58 percent. The regionalized Q7, 10 flow estimated for tributaries flowing into the study reach should be considered only as fair to poor in accuracy (Livingston, 1970). The augmentation from the proposed Yamcolo Reservoir could increase the Q7,10 flow in the Yampa River at Steamboat Springs to $48 \mathrm{ft}^{3} / \mathrm{s}\left(1.3 \mathrm{~m}^{3} / \mathrm{s}\right)$. The option of flow augmentation of $20 \mathrm{ft}^{3} / \mathrm{s}\left(0.6 \mathrm{~m}^{3} / \mathrm{s}\right)$ was used in evaluating the effects of treated wastewater effluent from the proposed regional treatment plant during September and December flow conditions on the Yampa River.

\section{Population Projections for Steamboat Springs}

A substantial seasonal variation in population in the Steamboat Springs area occurs each year because of summer and winter recreational activities. Because of this variation, two population indexes have been used in this study: peak-day and permanent population. The peak-day population is defined as the maximum daily population for a given year, and permanent population is defined as the average number of year-round residents in the Steamboat Springs area.

Population projections and extrapolations for 2010 based on studies by Gathers and Associates (1976) as revised by the Routt County Planning Commission and the U.S. Environmental Protection Agency (1977) (fig. 23) were used for the model-simulation phase of this study.

The projected population for 2010 was recommended by the Routt County Planning Commission (P. E. Stark, written commun., 1976) for use in the modelsimulation phase of this report. The projected peak-day population for 2010 is approximately 26,000 and the projected permanent population is 11,500 . These population estimates were determined by extending the graphical relationships in figure 23 to 2010. An assumed water use of $134 \mathrm{gal}\left(0.509 \mathrm{~m}^{3}\right)$ per capita per day was used in conjunction with the projected peak-day population of 26,000 and a maximum-design capacity of $3.5 \mathrm{Mgal}\left(13.1 \times 10^{3} \mathrm{~m}^{3}\right)$ per day for the proposed wastewater-treatment plant (F. J. Vogel, written commun., 1975). As noted in the wastewater-facilities plan (U.S. Environmenta1 


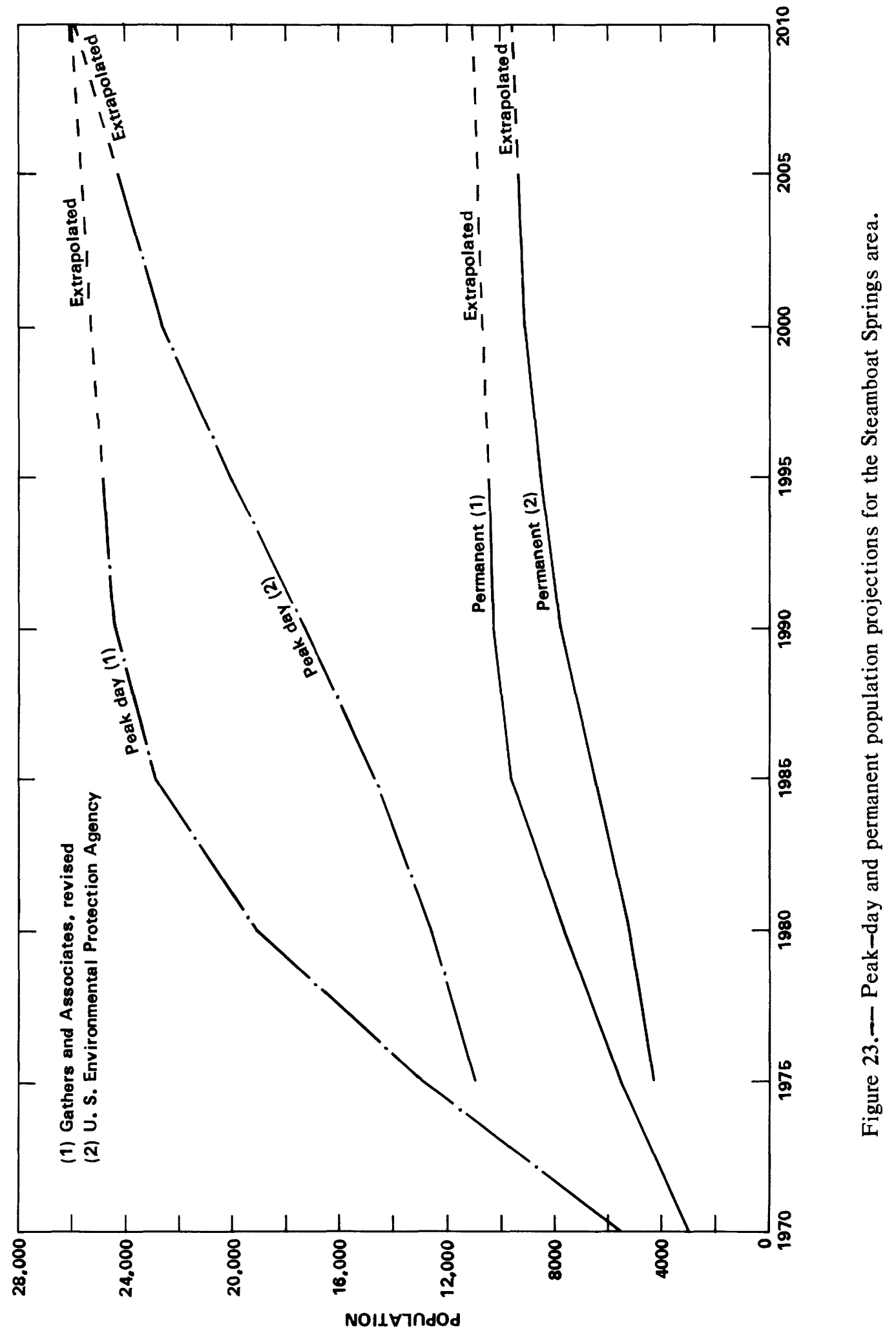


Protection Agency, 1977), there has been a large variation in the population projections for the Steamboat Springs area, both in terms of population and of the per-capita use of water. For the study reported here, the peak-daily population was used for the December modeling condition and the permanent population projection was used for the September modeling condition.

The population projections considered in this analysis (Gathers and Associates, 1976; U.S. Environmental Protection Agency, 1977) are considered only as indications of future growth. Because of the uncertainty of population projections, estimates for 2010 were used for the entire analysis. This promoted a maximum loading viewpoint of the stream reach from the proposed regional wastewater-treatment plant (U.S. Environmental Protection Agency, 1977).

MODEL SIMULATIONS

\section{Effluents from Existing Wastewater-Treatment Plants and 7-Day, 10-Year Streamflow}

Model simulations were conducted using the U.S. Geological Survey model for effluents from existing wastewater-treatment plants in the study reach, assuming low-flow conditions and population projections for 2010 . The nonaugmented $Q 7,10$ flow of $28 \mathrm{ft}^{3} / \mathrm{s}\left(0.78 \mathrm{~m}^{3} / \mathrm{s}\right)$ was considered. Also considered was a flow augmentation of $20 \mathrm{ft}^{3} / \mathrm{s}\left(0.56 \mathrm{~m}^{3} / \mathrm{s}\right)$ from the proposed Yamcolo Reservoir. The analysis assumed the same effluent conditions measured during the September 23-24, 1975, sampling period. The results of this analysis using both flow conditions for selected water-quality variables are shown on figures 24 to 27 . For the simulation phase, it was assumed that all model parameters were only temperature dependent. Therefore, for example, the simulation for December basically assumed the same biologic and $\mathrm{pH}$ conditions as in september. The amount of error induced because of this and other assumptions is not known.

The traveltime through the system, for the simulation phase of the study only, was estimated using a procedure described by Boning (1974). This procedure utilizes a technique of estimating traveltime as a function of discharge and mean streambed slope. After the traveltime data were computed, they were used in computations of subreach transit times and, also, of the stream-reaeration rates. A subsequent study of the traveltime and reaeration rates for the Yampa River has been completed (D. P. Bauer, R. E. Rathbun, and H. W. Lowham, written commun., 1977). Traveltime determined in the subsequent study is within 5 percent of the traveltime used in this study.

Simulated profiles for concentrations of CBODU are shown on figure 24. The largest concentrations, as expected, occur immediately downstream from the main wastewater-treatment plant at Steamboat Springs. No criteria concerning in-stream concentrations of this constituent have been proposed to date. 


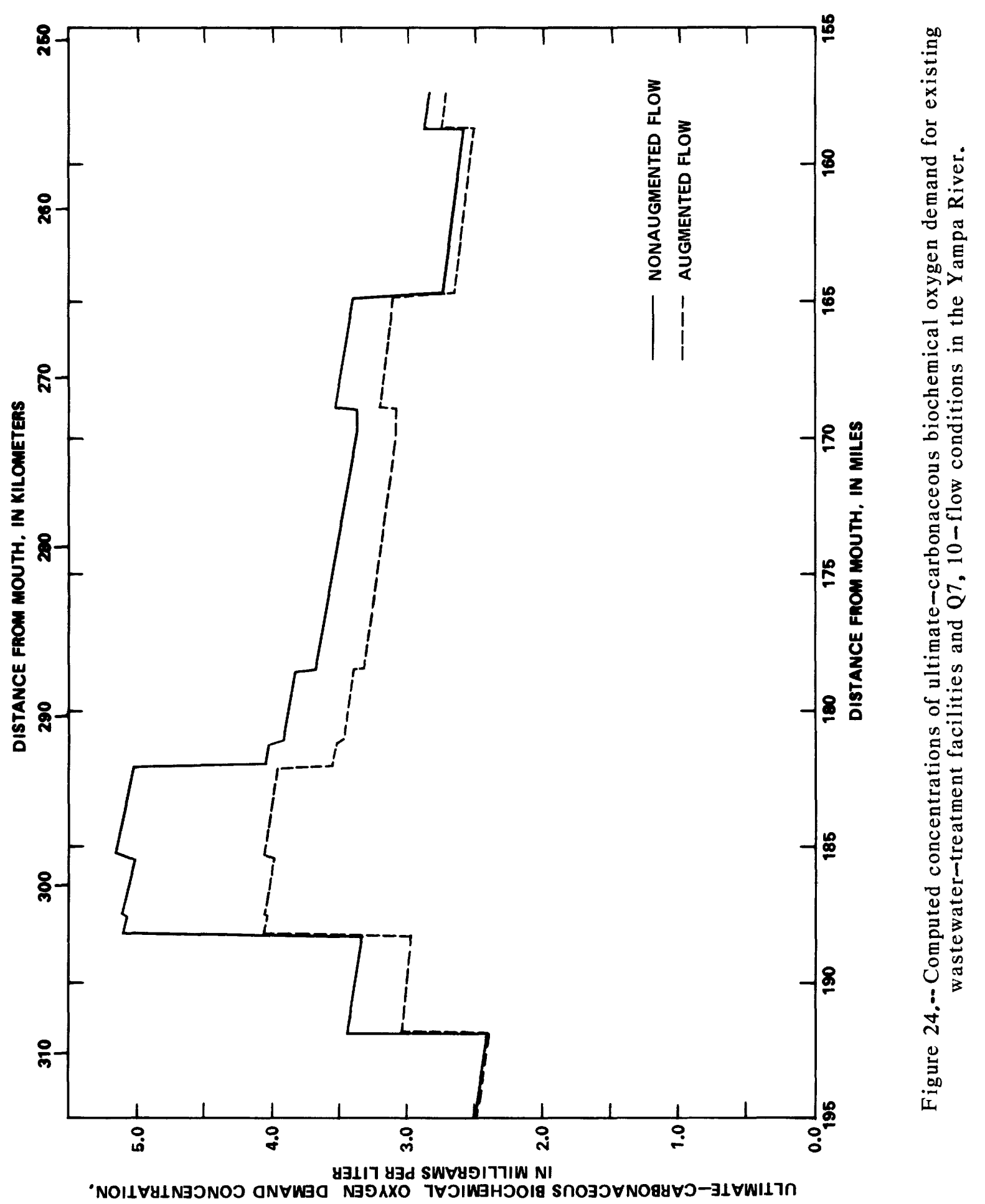


As shown on figure 25, the computed DO concentrations exceed by more than $2 \mathrm{mg} / \mathrm{L}$ the existing limit of $6.0 \mathrm{mg} / \mathrm{L}$ for a type Bl stream classification. Little increase in DO concentrations resulted from substituting augmented flow conditions in the model simulation (fig. 25).

Profiles for both computed ammonia-nitrogen and nonionized ammonia-nitrogen concentrations for the two flow conditions are shown on figure 26 . The model computed the ammonia-nitrogen concentrations, from which the nonionized ammonia-nitrogen concentrations then were computed using the tables compiled by Willingham (1976). An average value of $13^{\circ} \mathrm{C}$ for water temperature was assumed throughout the stream reach, and the median $\mathrm{pH}$ values for each of the main-stem sampling sites observed during the 24-hour sampling period in September 1975 were used. The results (fig. 26) show a maximum nonionized ammonia-nitrogen concentration of $0.03 \mathrm{mg} / \mathrm{L}$ for augmented flow conditions and $0.05 \mathrm{mg} / \mathrm{L}$ for nonaugmented flow conditions. Both concentrations exceed the proposed $0.02-\mathrm{mg} / \mathrm{L}$ concentration for a type B1 stream classification for a short distance downstream from the main wastewater-treatment plant at Steamboat Springs. The exact length of stream in which the nonionized ammonia-nitrogen concentration would exceed the proposed $0.02-\mathrm{mg} / \mathrm{L}$ standard cannot be determined, because of the uncertainty of the decay-rate coefficient for ammonia nitrogen and, also, because of the possible large use of ammonia nitrogen by different algal forms, discussed earlier. The results presented above also can vary depending on the actual water temperature and $\mathrm{pH}$ values. For example, considering an acceptable $\mathrm{pH}$ range from 6 to 9 and a water temperature from $0^{\circ}$ to $20^{\circ} \mathrm{C}$, the maximum nonionized ammonia-nitrogen concentration could range from 0 to $0.11 \mathrm{mg} / \mathrm{L}$ for augmented flow conditions and from 0 to $0.16 \mathrm{mg} / \mathrm{L}$ for nonaugmented flow conditions (table 4 ).

The computed concentrations of fecal-coliform bacteria for existing conditions are shown on figure 27. The computed concentrations are significantly less than the maximum of 1,000 colonies/100 mL allowed for type B1 stream classification (Colorado Department of Health, 1974). The greatest difference in computed coliform-bacteria concentrations based on augmented versus nonaugmented flow conditions occurs upstream from the Elk River.

\section{Proposed Regional Wastewater-Treatment Plant with 1978 Standards for Effluent}

The effects of discharge from the proposed regional wastewater-treatment plant on the Yampa River were simulated using the U.S. Geological Survey model for the following conditions: Permanent population for September 2010 and Q7,10 f1ow of $28 \mathrm{ft}^{3} / \mathrm{s}\left(0.78 \mathrm{~m}^{3} / \mathrm{s}\right)$, permanent population for September 2010 and $Q 7,10 \mathrm{flow}$ with $20 \mathrm{ft}^{3} / \mathrm{s}\left(0.56 \mathrm{~m}^{3} / \mathrm{s}\right)$ flow augmentation, peak-daily population for December 2010 and Q7,10 flow, and peak-daily population for December 2010 and $Q 7,10$ flow with $20 \mathrm{ft}^{3} / \mathrm{s}\left(0.56 \mathrm{~m}^{3} / \mathrm{s}\right)$ flow augmentation. Treatmentplant effluent was assumed to meet the proposed standards for 1978 (table 5). The Q7,10 flow was assumed for September and December because low-flow occurs in both months in the Yampa River at Steamboat Springs (figs. 5, 6). The median $\mathrm{pH}$ values obtained during the 24-hour data-collection effort were assumed for both the September and December conditions. Water temperatures of 


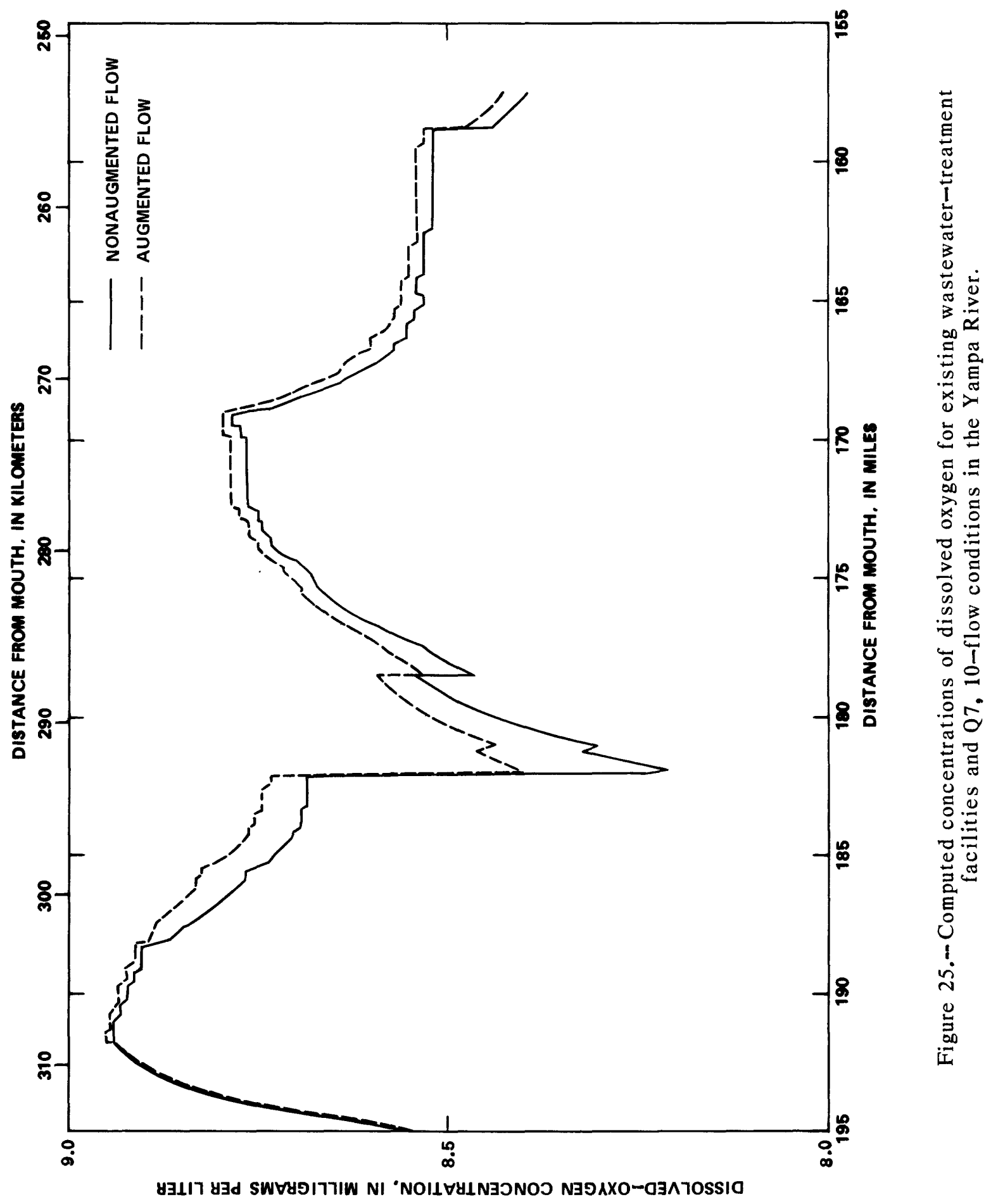




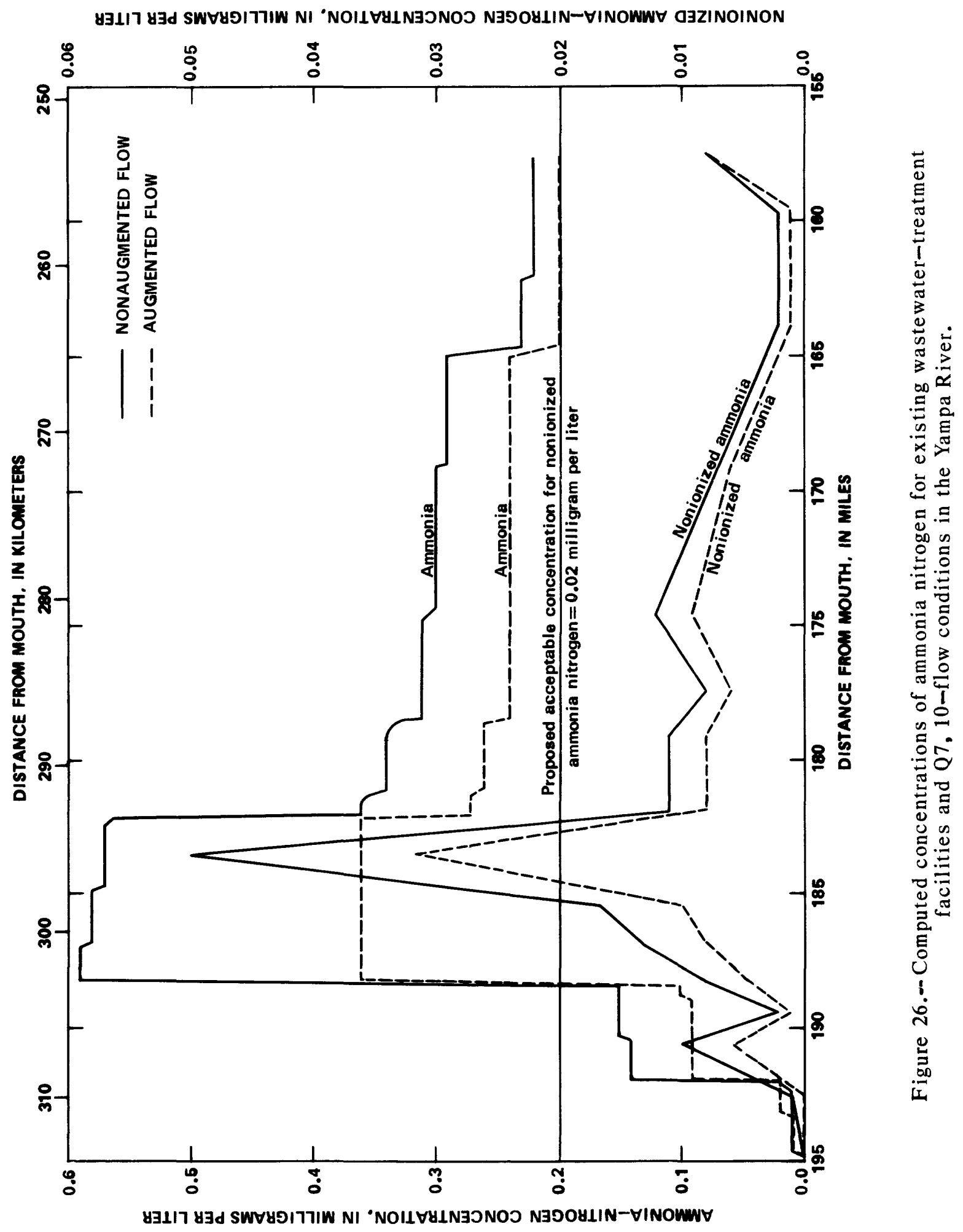




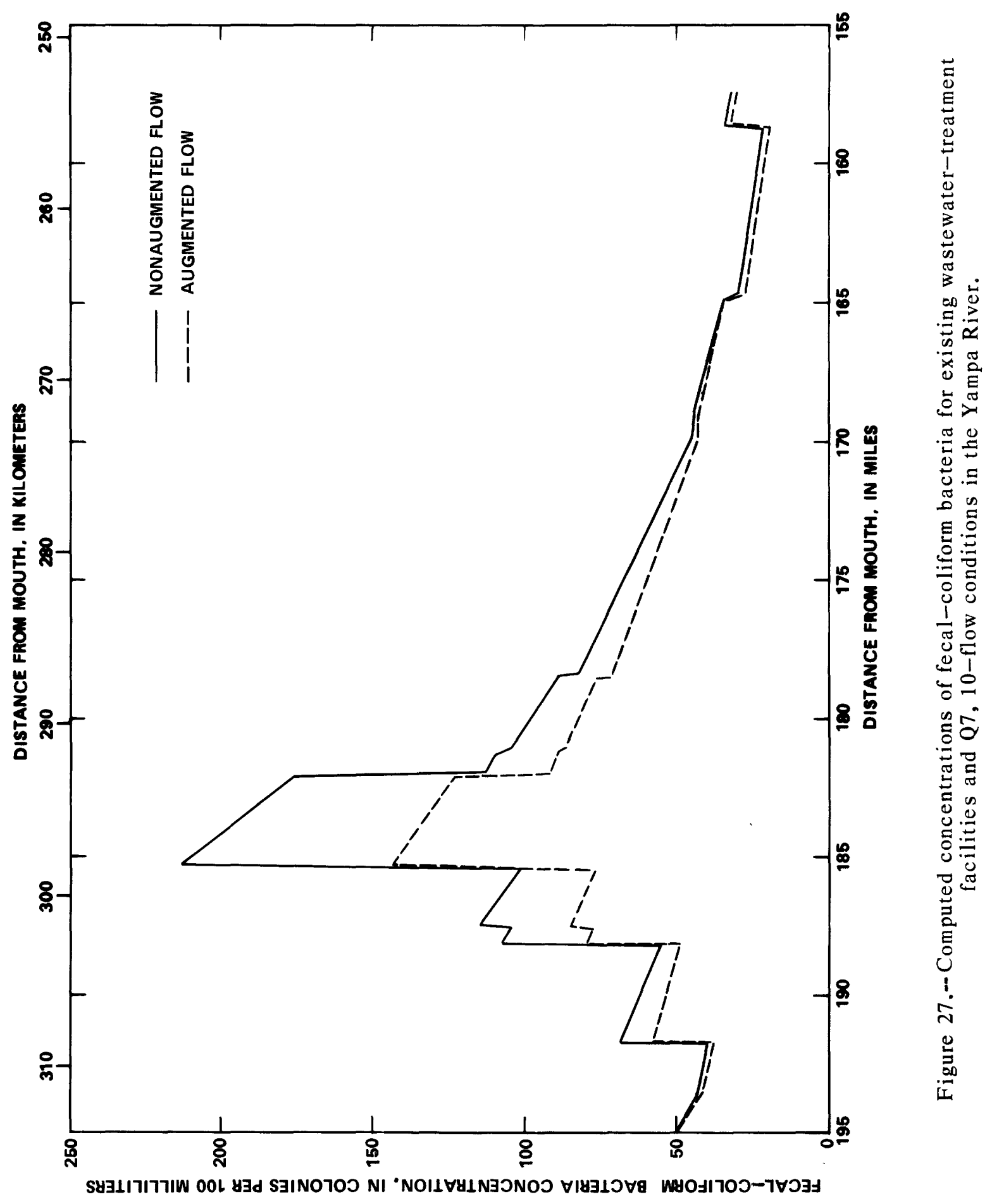


$13^{\circ} \mathrm{C}$ for September and $2^{\circ} \mathrm{C}$ for December were assumed and were based on average yearly harmonic-mean water temperatures for Steamboat Springs (T. D. Steele, written commun., 1977). The regional treatment-plant discharge was based on projected population and $134 \mathrm{gal}\left(0.509 \mathrm{~m}^{3}\right)$ per capita per day for the plant location (see page 40) 188 river-miles (303 km) upstream from the mouth.

The computed profiles for CBODU are shown on figure 28 and for DO on figure 29. The profile patterns were distinct for the September and December conditions. The effects of flow augmentation were negligible in both instances. The simulated DO profiles indicated only a slight DO sag downstream from Steamboat Springs (fig. 29). The differences between the September and December Do profiles can be attributed to the different watertemperature conditions. The sharp increase of DO on the December profile at the start of the curve is a result of an assumed $8.5-\mathrm{mg} / \mathrm{L}$ initial concentration, much below the saturated DO concentration.

The nutrient species modeled included ammonia nitrogen (fig. 30), total nitrogen (fig. 31), and orthophosphate (fig. 32). The profiles for ammonianitrogen and orthophosphate concentrations indicate that large differences between September and December seasonal conditions and the effects of augmented flow conditions are discernible. The ammonia-nitrogen concentrations in the Yampa River for the two periods were computed assuming the treatment-plant effluent contained $9.0 \mathrm{mg} / \mathrm{L}$ ammonia nitrogen, the proposed standard for December 1978; and $2.8 \mathrm{mg} / \mathrm{L}$, the proposed standard for September 1978 (table 5). For each of the four conditions modeled, the maximum concentrations of ammonia nitrogen, total nitrogen, and orthophosphate occurred downstream from the proposed regional wastewater-treatment plant to the confluence of the Elk River in December. The profiles of nonionized ammonia-nitrogen concentrations for the four assumed conditions are shown on figure 33. The concentrations of nonionized ammonia nitrogen shown of the two profiles for the augmented and nonaugmented flow conditions computed for December exceed the proposed $0.02-\mathrm{mg} / \mathrm{L}$ concentration for a type B1 stream classification with maximum concentrations of $0.042 \mathrm{mg} / \mathrm{L}$ for augmented flow and $0.065 \mathrm{mg} / \mathrm{L}$ for nonaugmented flow. These concentrations will vary depending on the actual water-temperature and $\mathrm{pH}$ values. For example, for the acceptable $\mathrm{pH}$ range of 6 to 9 and a water temperature from $0^{\circ}$ to $20^{\circ} \mathrm{C}$, the nonionized ammonia-nitrogen concentration could range from 0 to $0.27 \mathrm{mg} / \mathrm{L}$ for augmented flow and from 0 to $0.42 \mathrm{mg} / \mathrm{L}$ for nonaugmented flow in December.

The assumed ammonia-nitrogen concentration of the proposed treatmentplant effluent was varied in the model to evaluate its effect on the nonionized ammonia-nitrogen concentrations in the Yampa River. The results for December are shown on figure 34. An ammonia-nitrogen concentration for the plant effluent of $3 \mathrm{mg} / \mathrm{L}$ resulted in a maximum of $0.025 \mathrm{mg} / \mathrm{L}$ of nonionized ammonia nitrogen for nonaugmented flow. The results for a flow augmentation of $20 \mathrm{ft}^{3} / \mathrm{s}\left(0.56 \mathrm{~m}^{3} / \mathrm{s}\right)$ in December also are shown on figure 34. An ammonianitrogen concentration of $4 \mathrm{mg} / \mathrm{L}$ in the effluent resulted in a maximum of about $0.02 \mathrm{mg} / \mathrm{L}$ of nonionized ammonia nitrogen in the study reach. The analysis indicates that flow augmentation may allow an approximate 25-percent increase in the permissible ammonia-nitrogen waste loading in the study reach, relative to the $Q 7,10-f 10 w$ statistics. 


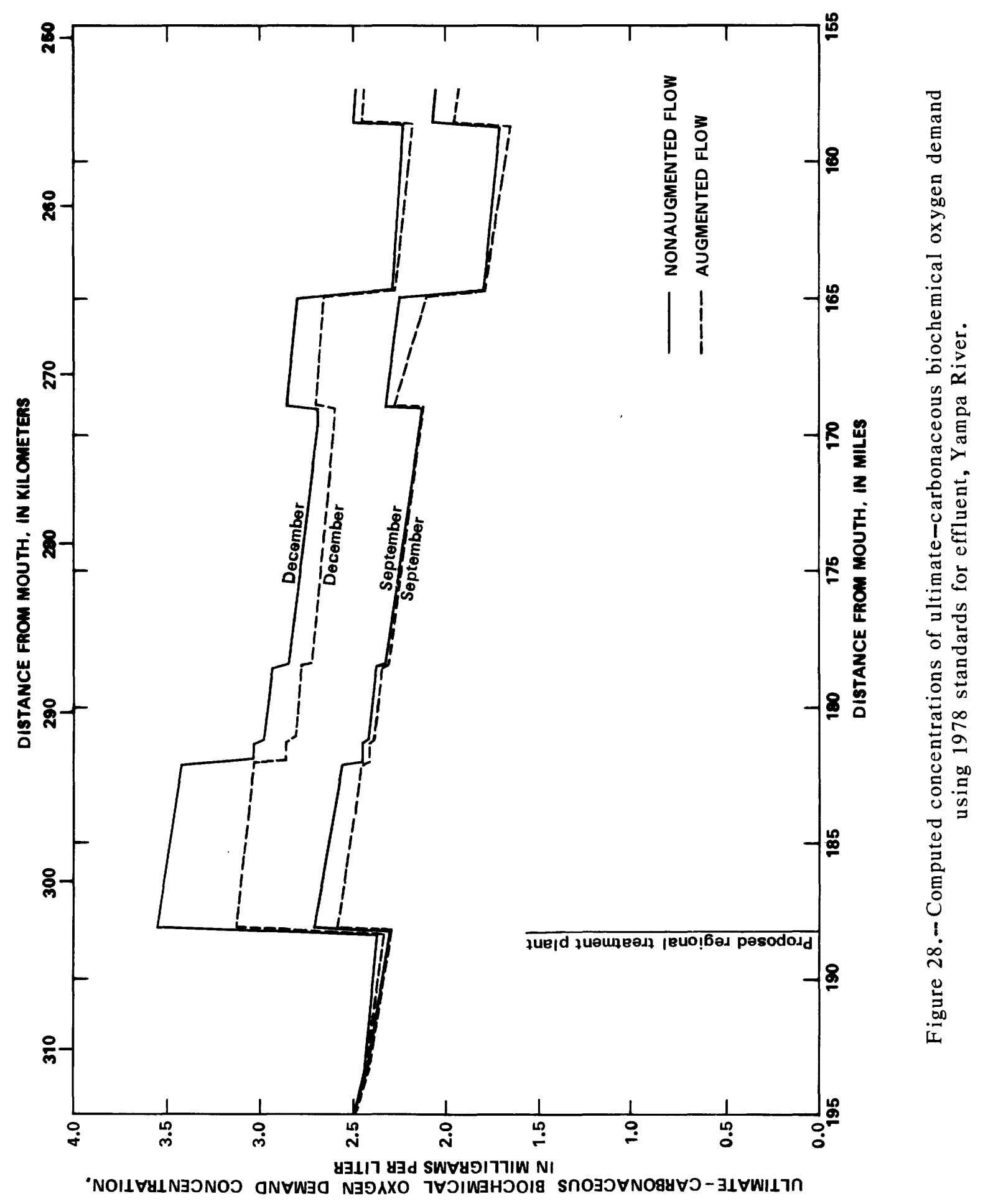




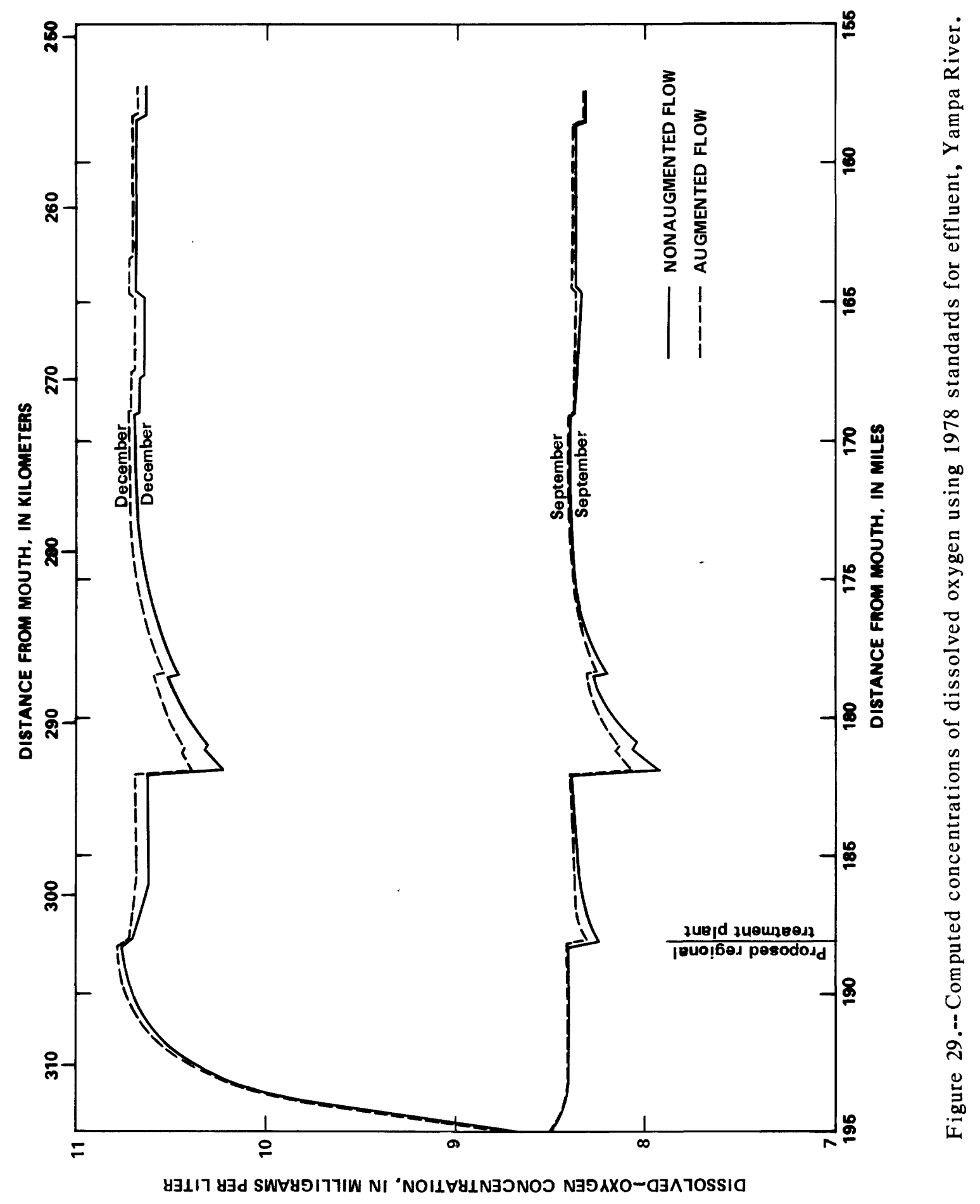




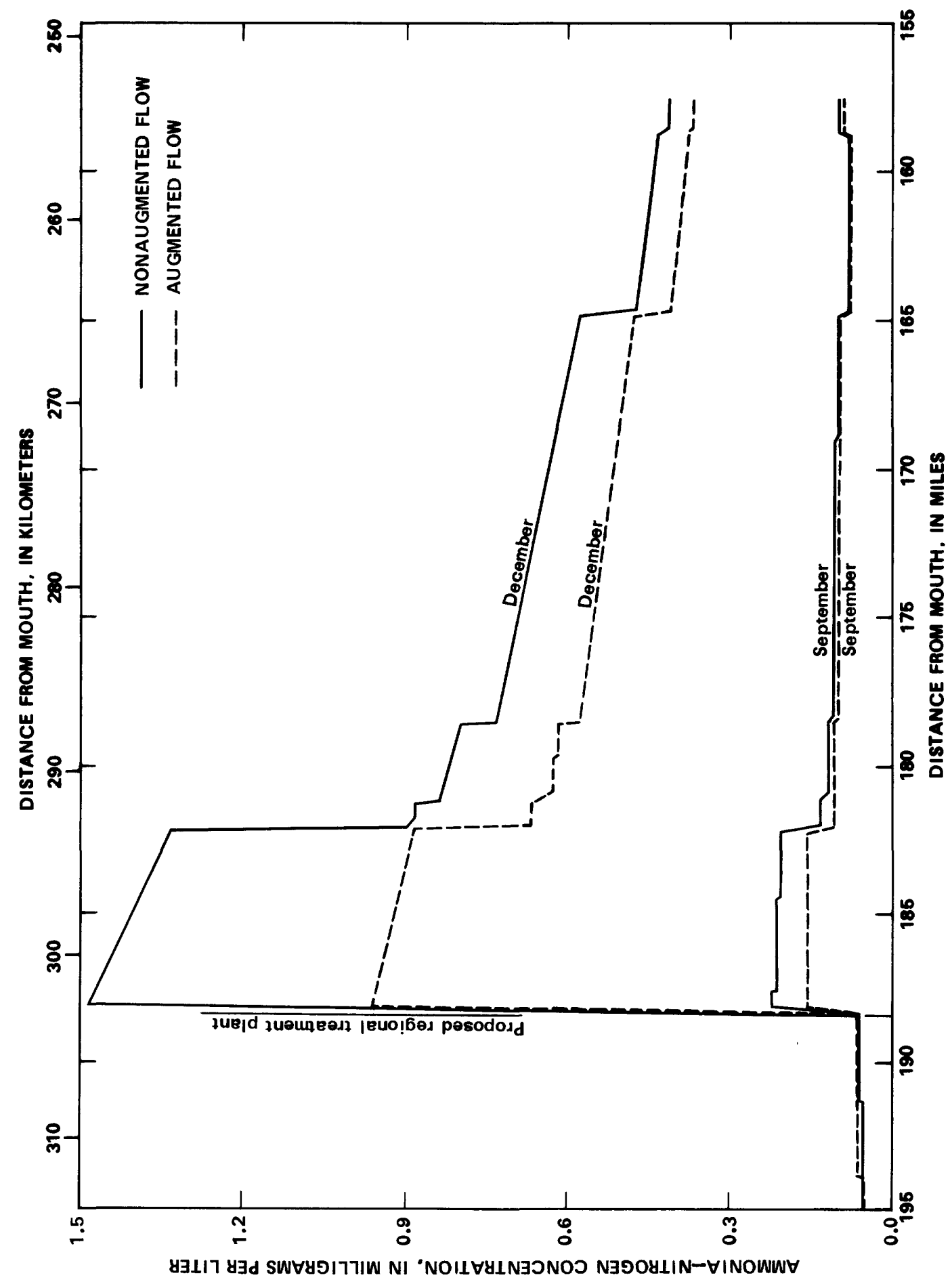

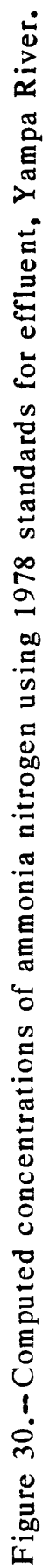




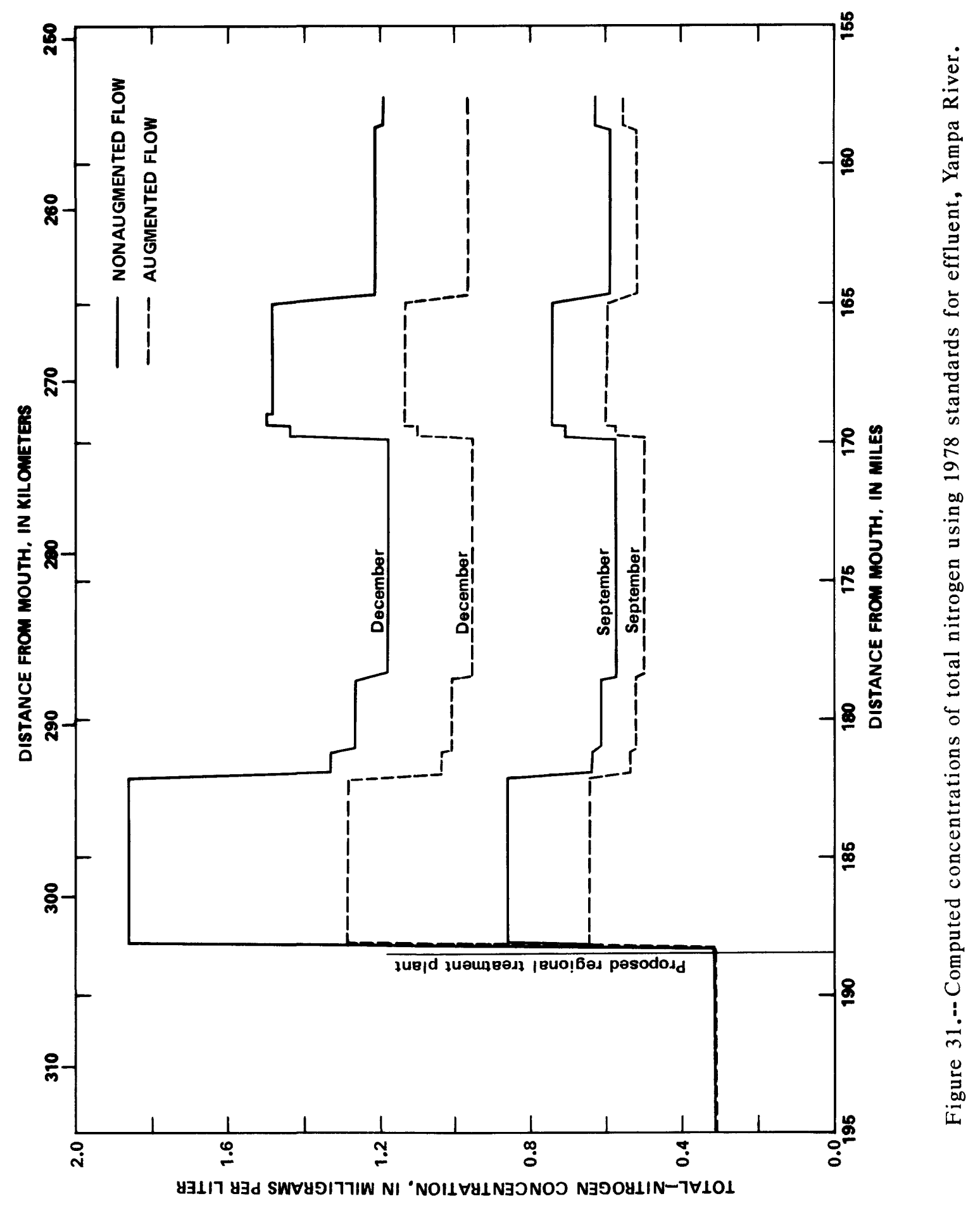




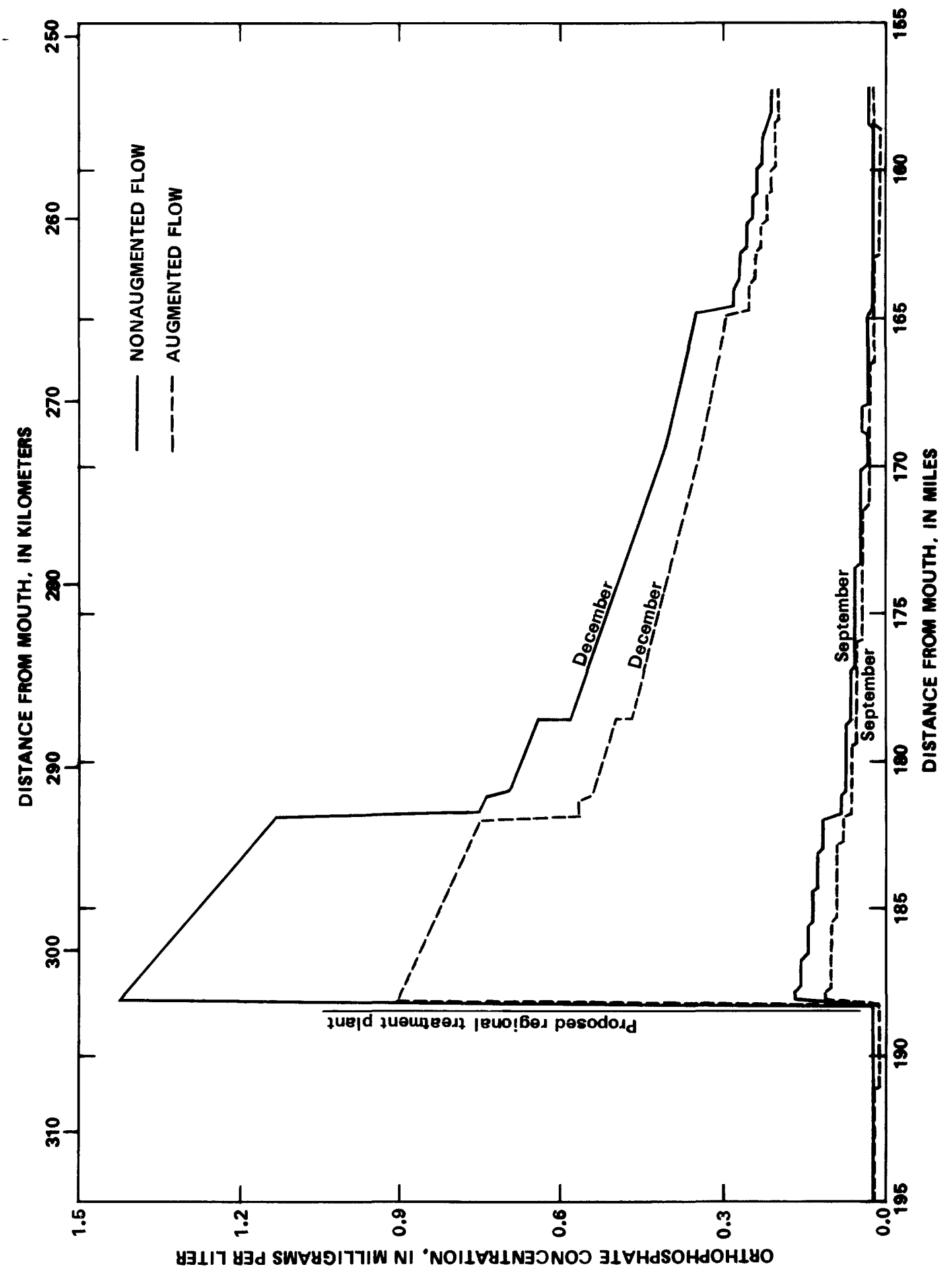

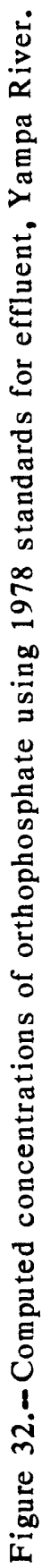




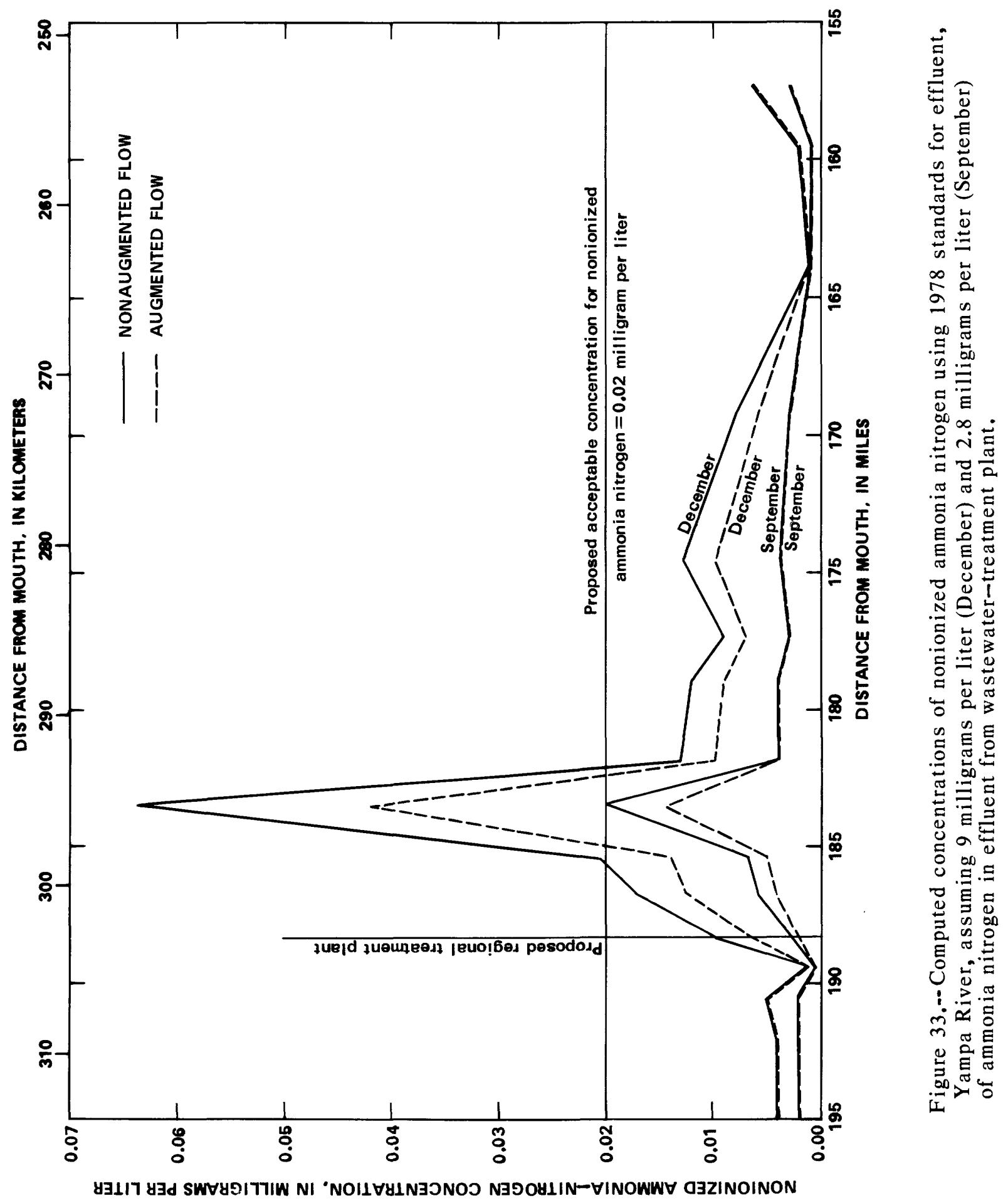




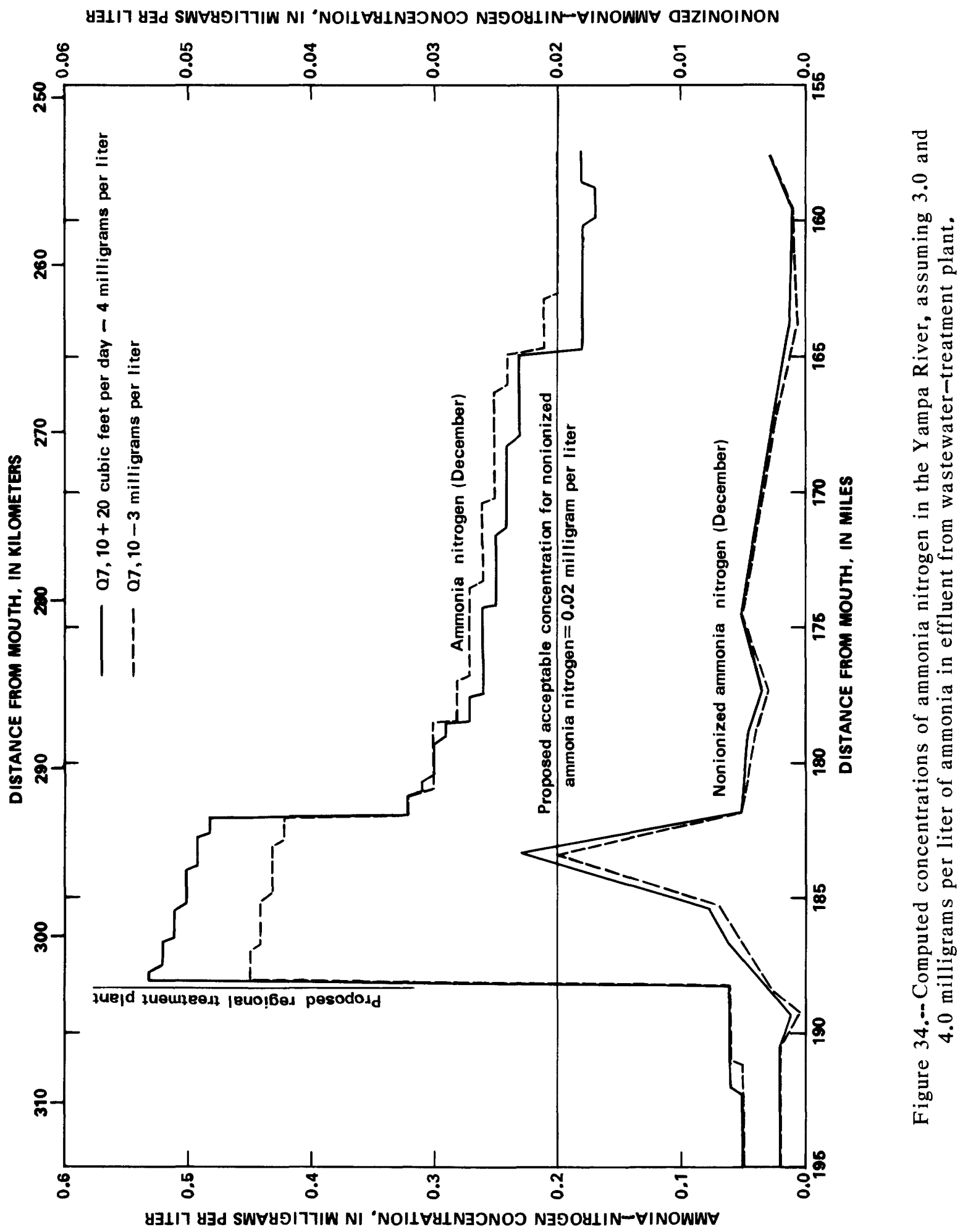


The simulated profile for concentrations of fecal-coliform bacteria is shown on figure 35. The maximum concentration of fecal-coliform bacteria estimated by the model was less than 50 colonies/100 mL. Substantial increases in concentration of fecal-coliform bacteria (fig. 35) are caused by discharge from the proposed regional wastewater-treatment plant at Steamboat Springs and by discharge from the existing wastewater-treatment plant at Hayden into Dry Creek, which is tributary to the Yampa River, 159 river-miles $(256 \mathrm{~km})$ upstream from the mouth. Even with these increases, the concentrations of fecal-coliform bacteria are significantly less than the acceptable 1,000 colonies/100 mL.

\section{Proposed Regional Wastewater-Treatment Plant with 1985 Standards for Effluent}

The effects of effluent discharge from the proposed regional treatment plant on the Yampa River were simulated by the U.S. Geological Survey model assuming compliance with the proposed 1985 standards for effluent (table 5). A11 other assumptions are the same as described in the previous section.

Some of the results of the model analysis are shown on figures 36 and 37 . The figures show profiles for ammonia-nitrogen (fig. 36) and total-nitrogen (fig. 37) concentrations. Assuming the more stringent 1985 standards for effluent (table 5), the computed concentrations of all constituents were less than the standards for type B1 streams. The results for nonionized ammonianitrogen concentrations are not shown. The concentrations were computed but were less than $0.01 \mathrm{mg} / \mathrm{L}$, significantly less than the recommended standard of $0.02 \mathrm{mg} / \mathrm{L}$ (Colorado Department of Health, written commun., 1976; U.S. Environmental Protection Agency, 1976) for a type Bl stream.

\section{Ammonia-Nitrogen Concentrations for Varying Conditions and 1978 Standards for Effluent}

The study reach was modeled assuming 1978 standards for effluent from the regional treatment plant (table 5), Q7,10 flow in the Yampa River at Steamboat Springs, and several projected populations and effluent-discharge rates. The results of the analyses are given in tables 6 and 7 . The projection alternatives included peak-day populations for December and permanent populations for September. The population estimates are from the U.S. Environmental Protection Agency (1977) for 1990, 1995, 2000, 2005, and 2010. The alternative effluent-discharge rates considered were 100,125 , and $150 \mathrm{gal}(0.38,0.47$, and $0.57 \mathrm{~m}^{3}$ ) per capita per day.

For permanent populations (table 6), the maximum concentrations of ammonia nitrogen ranged from 0.15 to $0.24 \mathrm{mg} / \mathrm{L}$ and nonionized ammonia nitrogen from 0.015 to $0.023 \mathrm{mg} / \mathrm{L}$. Thus, the maximum nonionized ammonia-nitrogen concentrations exceeded the recommended standard of $0.02 \mathrm{mg} / \mathrm{L}$ by 15 percent. The water temperature was assumed to be $13^{\circ} \mathrm{C}$ throughout the study reach and $\mathrm{pH}$ values were assumed to be similar to those measured during September 23-24, 1975. 


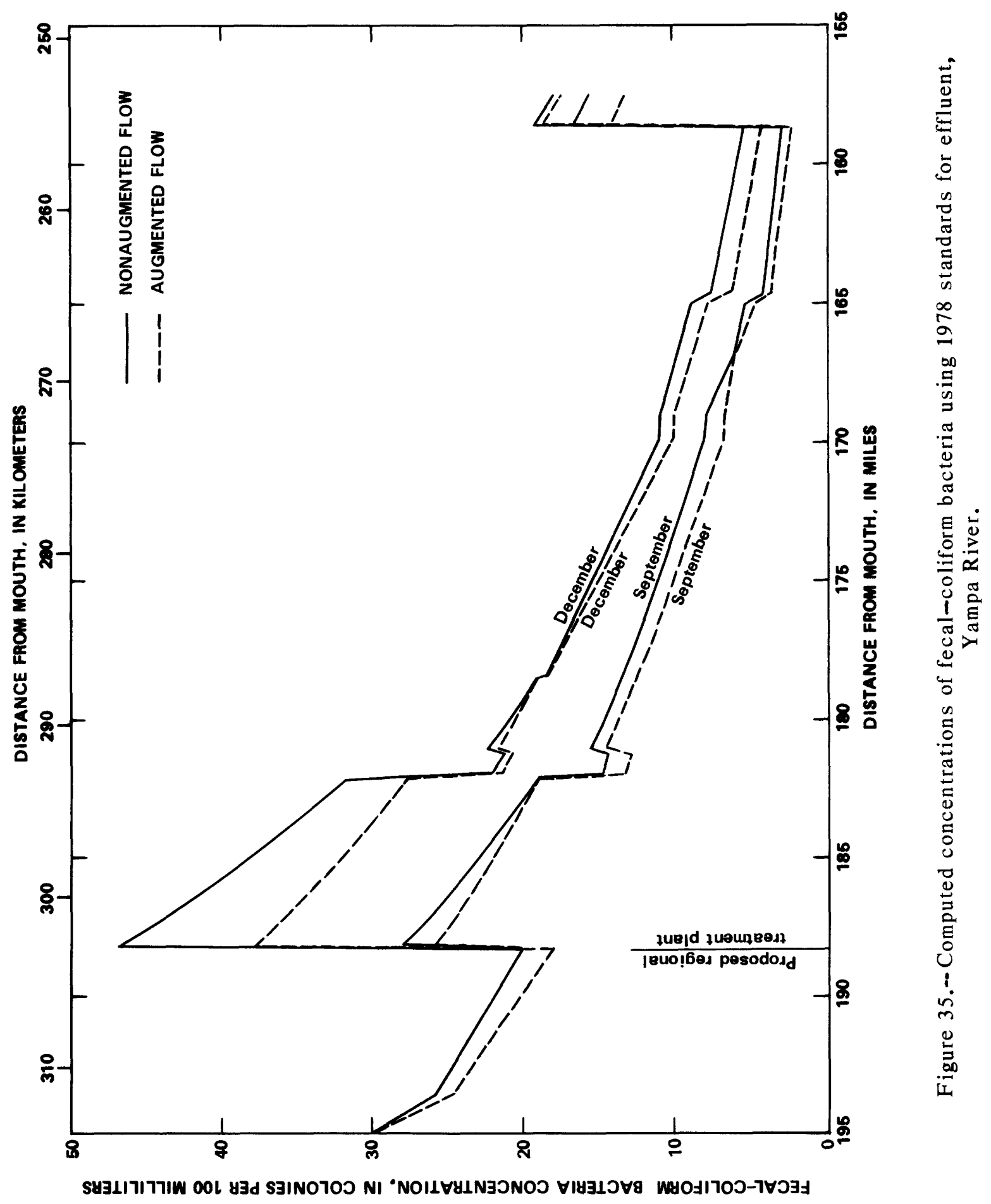




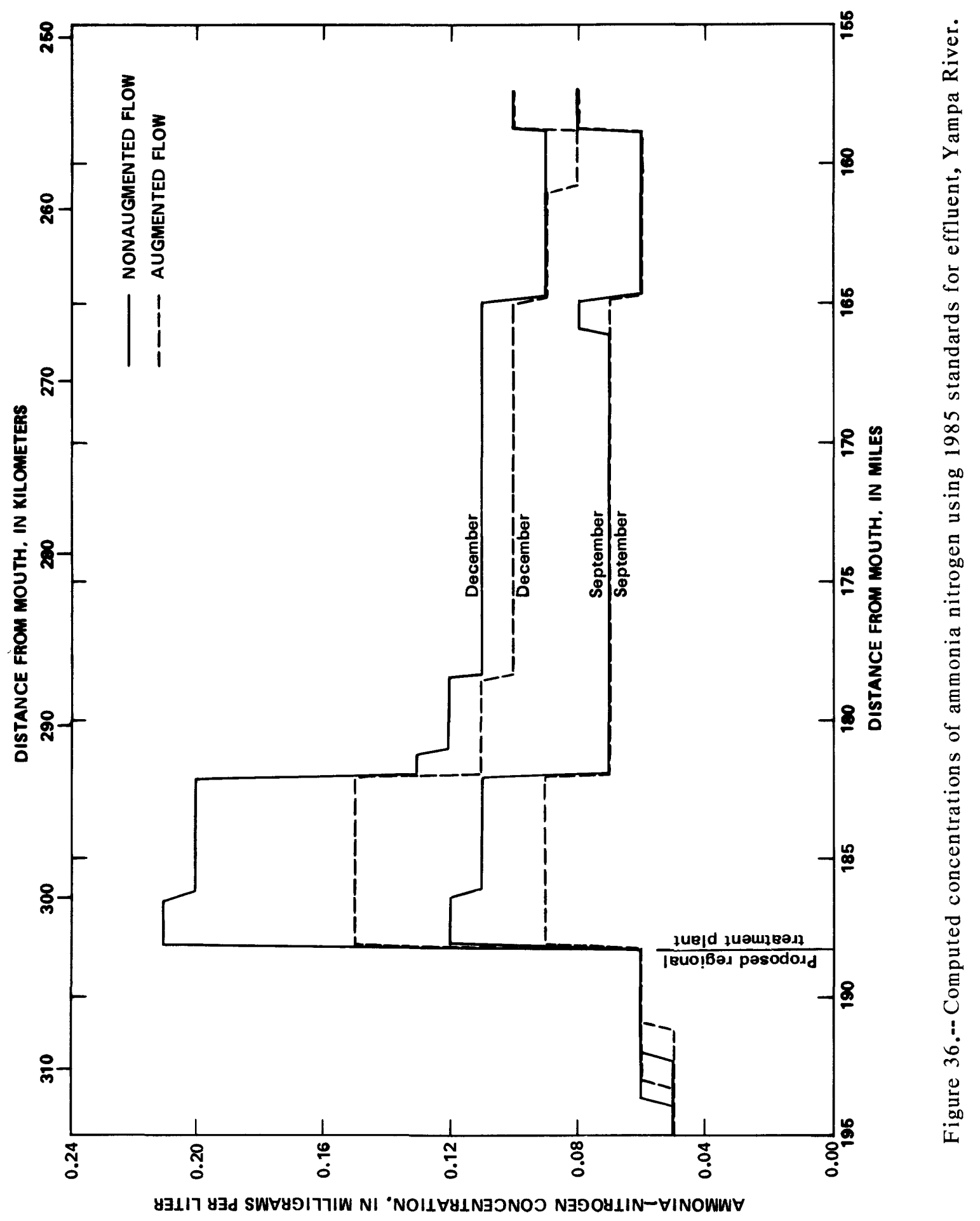




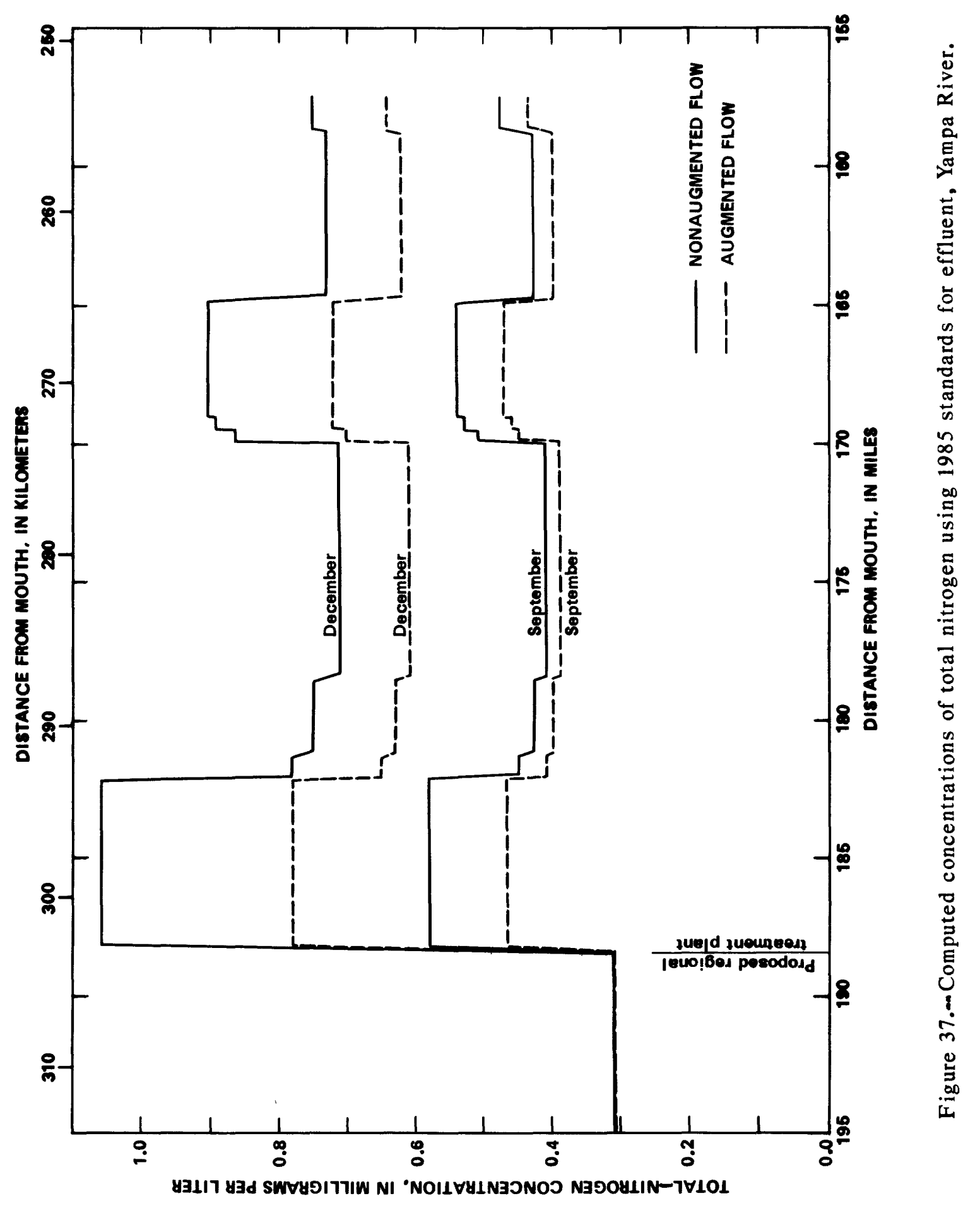


Table 6.--Maximum computed concentrations of ammonia nitrogen and nonionized ammonia nitrogen for permanent populations, and using 1978 standards for effluent, Yampa River, Steamboat Springs to Hayden, Colo.

\begin{tabular}{|c|c|c|c|c|}
\hline \multirow[b]{2}{*}{ Year } & \multirow{2}{*}{$\begin{array}{l}\text { Projected } \\
\text { permanent } \\
\text { population }\end{array}$} & \multirow{2}{*}{$\begin{array}{c}\text { Effluent } \\
\text { (gallons } \\
\text { per capita) }\end{array}$} & \multicolumn{2}{|c|}{$\begin{array}{l}\text { Maximum concentration, } \\
\text { in milligrams per liter }\end{array}$} \\
\hline & & & $\begin{array}{l}\text { Ammonia } \\
\text { nitrogen }\end{array}$ & $\begin{array}{l}\text { Nonionized } \\
\text { ammonia } \\
\text { nitrogen }\end{array}$ \\
\hline $\begin{array}{l}1990 \\
1995 \\
2000 \\
2005 \\
2010\end{array}$ & $\begin{array}{r}8,200 \\
9,000 \\
9,600 \\
9,750 \\
10,000\end{array}$ & $\begin{array}{l}100 \\
100 \\
100 \\
100 \\
100\end{array}$ & $\begin{array}{r}0.15 \\
.16 \\
.18 \\
.18 \\
.19\end{array}$ & $\begin{array}{r}0.015 \\
.016 \\
.017 \\
.017 \\
.018\end{array}$ \\
\hline $\begin{array}{l}1990 \\
1995 \\
2000 \\
2005 \\
2010\end{array}$ & $\begin{array}{r}8,200 \\
9,000 \\
9,600 \\
9,750 \\
10,000\end{array}$ & $\begin{array}{l}125 \\
125 \\
125 \\
125 \\
125\end{array}$ & $\begin{array}{r}0.19 \\
.19 \\
.21 \\
.21 \\
.21\end{array}$ & $\begin{array}{r}0.018 \\
.018 \\
.020 \\
.020 \\
.020\end{array}$ \\
\hline $\begin{array}{l}1990 \\
1995 \\
2000 \\
2005 \\
2010\end{array}$ & $\begin{array}{r}8,200 \\
9,000 \\
9,600 \\
9,750 \\
10,000\end{array}$ & $\begin{array}{l}150 \\
150 \\
150 \\
150 \\
150\end{array}$ & $\begin{array}{r}0.21 \\
.22 \\
.23 \\
.23 \\
.24\end{array}$ & $\begin{array}{r}0.020 \\
.021 \\
.022 \\
.022 \\
.023\end{array}$ \\
\hline
\end{tabular}

Results of this analysis for the peak-day populations indicated that the maximum concentrations of ammonia nitrogen ranged from 0.81 to $1.55 \mathrm{mg} / \mathrm{L}$ and nonionized ammonia-nitrogen concentrations ranged from 0.036 to $0.070 \mathrm{mg} / \mathrm{L}$ (table 7). All nonionized ammonia-nitrogen concentrations for peak-day populations exceeded the recommended standard of $0.02 \mathrm{mg} / \mathrm{L}$. The water temperature was assumed to be $2^{\circ} \mathrm{C}$ throughout the study reach and $\mathrm{pH}$ values were assumed to be similar to those measured during September 23-24, 1975. 
Table 7.--Maximum computed concentrations of ammonia nitrogen and nonionized ammonia nitrogen for peak-day populations, and using 1978 standards for effluent, Yampa River, Steamboat Springs to Hayden, Colo.

\begin{tabular}{llccc}
\hline & & \multicolumn{2}{c}{$\begin{array}{c}\text { Maximum concentration, } \\
\text { in milligrams per liter }\end{array}$} \\
\cline { 4 - 5 } & $\begin{array}{l}\text { Projected } \\
\text { peak-day } \\
\text { population }\end{array}$ & $\begin{array}{c}\text { Effluent } \\
\text { (gallons } \\
\text { per capita) }\end{array}$ & $\begin{array}{c}\text { Ammonia } \\
\text { nitrogen }\end{array}$ & $\begin{array}{c}\text { Nonionized } \\
\text { ammonia } \\
\text { nitrogen }\end{array}$ \\
\hline 1990 & 17,000 & 100 & 0.81 & 0.036 \\
1995 & 20,500 & 100 & .94 & .042 \\
2000 & 23,000 & 100 & 1.04 & .047 \\
2005 & 24,500 & 100 & 1.09 & .049 \\
2010 & 26,000 & 100 & 1.11 & .050 \\
1990 & 17,500 & 125 & 0.99 & 0.044 \\
1995 & 20,500 & 125 & 1.14 & .051 \\
2000 & 23,000 & 125 & 1.23 & .055 \\
2005 & 24,500 & 125 & 1.30 & .058 \\
2010 & 26,000 & 125 & 1.33 & .059 \\
1990 & 17,500 & 150 & 1.16 & 0.052 \\
1995 & 20,500 & 150 & 1.33 & .059 \\
2000 & 23,000 & 150 & 1.44 & .064 \\
2005 & 24,500 & 150 & 1.55 & .068 \\
2010 & 26,000 & 150 & & .070 \\
\hline
\end{tabular}

\section{STREAM BIOLOGICAL CONDITIONS}

A concurrent assessment of periphyton and macroinvertebrates was conducted cooperatively by personnel of the U.S. Environmental Protection Agency and U.S. Geological Survey for the 16 main-stem locations in the study reach. Sixteen of the sampling locations were at the main-stem locations used in the 24-hour study (table 2), and one additional site was located between YM-13 and YM-14. The macroinvertebrate data are discussed in a report by Eddy (1975). The diversity of the benthic communities identified from the samples was found to be related closely to the known point sources of effluent discharging to the Yampa River from wastewater-treatment plants. The mean diversity-index values (Slack and others, 1973) generally decreased in a downstream direction from the point-source discharges in the study reach.

The diversity-index values were compared to ammonia-nitrogen and orthophosphate concentrations estimated during the model-calibration phase. The 
results of this comparison are shown on figure 38. A general inverse relationship between the various nutrient concentrations and mean diversity of the benthic invertebrates is indicated (correlation coefficient, $r=0.7$ for ammonia nitrogen and $r=0.6$ for orthophosphate). Other water-quality constituents that were compared with the mean diversity values included: CBODU, water temperature, total phosphorus, and Kjeldahl nitrogen. The correlations of these latter constituents to the mean diversity data were relatively low (correlation coefficients, $r=0.2$ to 0.4 ).

A comparison of the mean total number of various benthic organisms and both orthophosphate and ammonia-nitrogen concentrations is shown on figure 39. There is no apparent relationship between the nutrient concentrations and the mean total number of organisms observed along the stream. Periphyton data that were collected at the 16 main-stem locations are tabulated in table 8 . Periphyton populations were sampled using plastic strips suspended in the stream channe1 (Slack and others, 1973, p. 88-89). The strips for the 16 main-stem sites were placed in the stream during early September 1975 and were removed approximately 4 weeks later. These data also were plotted against the benthic diversity index and total numbers of organisms. No trend or bivariate relationship was indicated.

Table 8.--Periphyton data, Yampa River, Steamboat Springs to Hayden, Colo., August-September 1975

\begin{tabular}{|c|c|c|c|c|}
\hline Location ${ }^{1}$ & $\begin{array}{l}\text { Periphyton } \\
\text { ash weight } \\
\quad\left(\mathrm{g} / \mathrm{m}^{2}\right)\end{array}$ & $\begin{array}{l}\text { Periphyton } \\
\text { dry weight } \\
\qquad\left(\mathrm{g} / \mathrm{m}^{2}\right)\end{array}$ & $\begin{array}{l}\text { Periphyton } \\
\text { chlorophy 1 1-a } \\
\left(\mathrm{mg} / \mathrm{m}^{2}\right)\end{array}$ & $\begin{array}{l}\text { Periphyton } \\
\text { chlorophy 1 1-b } \\
\left(\mathrm{mg} / \mathrm{m}^{2}\right)\end{array}$ \\
\hline 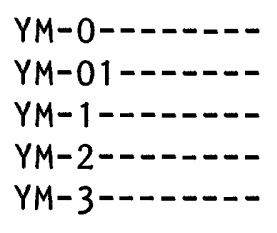 & $\begin{array}{l}4.6 \\
12 \\
3.5 \\
4.2 \\
6.1\end{array}$ & $\begin{array}{l}6.5 \\
15 \\
15 \\
6.1 \\
9.5\end{array}$ & $\begin{array}{l}5.0 \\
6.3 \\
4.1 \\
5.0 \\
4.8\end{array}$ & $\begin{array}{r}0.8 \\
.6 \\
.1 \\
.6 \\
.4\end{array}$ \\
\hline 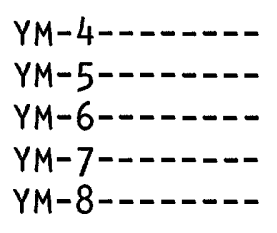 & $\begin{array}{l}7.6 \\
44 \\
1.2 \\
1.0 \\
5.1\end{array}$ & $\begin{array}{l}13 \\
58 \\
1.7 \\
1.8 \\
7.6\end{array}$ & $\begin{array}{l}8.9 \\
92 \\
3.8 \\
5.0 \\
3.8\end{array}$ & $\begin{array}{l}.5 \\
.0 \\
.3 \\
.2 \\
.3\end{array}$ \\
\hline 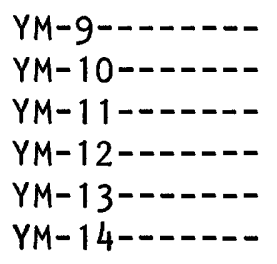 & $\begin{array}{r}4.3 \\
.2 \\
11^{6} \\
6.8 \\
7.0 \\
58^{-0}\end{array}$ & $\begin{array}{l}5.9 \\
.5 \\
27 \\
20 \\
9.5 \\
71\end{array}$ & $\begin{array}{l}1.9 \\
.3 \\
10 \\
9.2 \\
4.3 \\
59\end{array}$ & $\begin{array}{r}.2 \\
.0 \\
.4 \\
.5 \\
.5 \\
1.2\end{array}$ \\
\hline
\end{tabular}

${ }^{1}$ See figure 6 , and table 2 . 
(sw

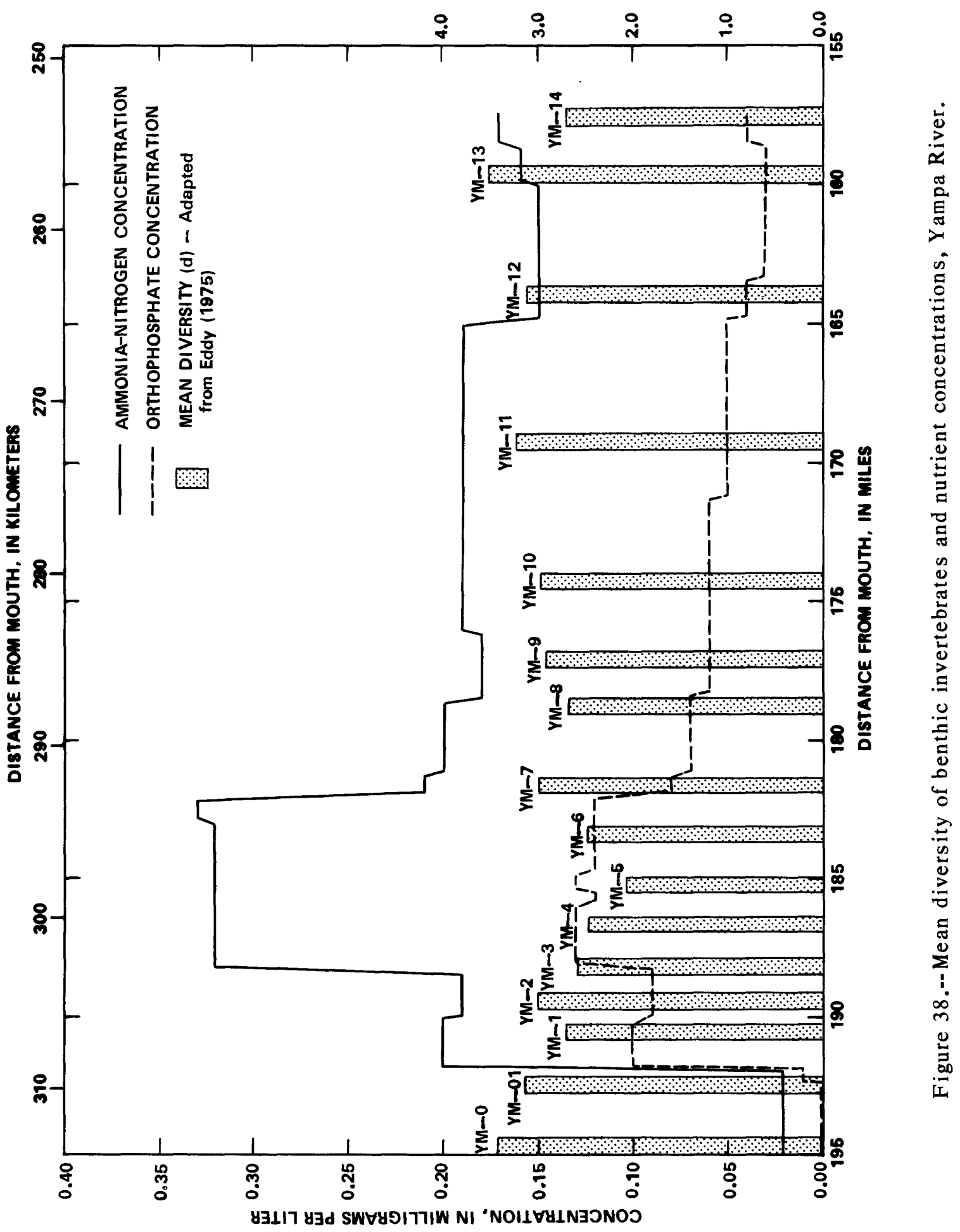




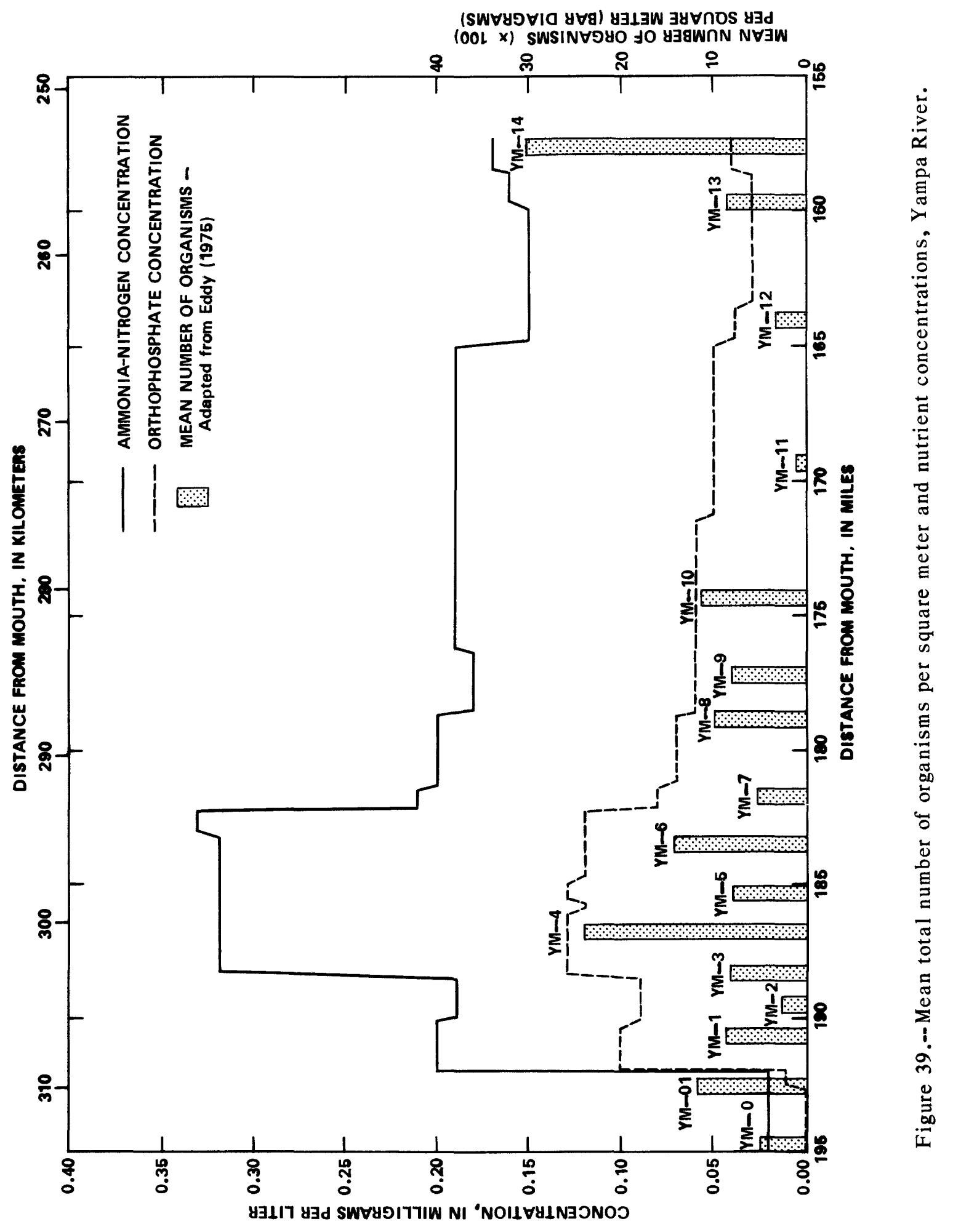


A study of the aquatic insects in the Yampa and White Rivers also has been completed (Ames, 1977). The results of the study indicated an abundance of insects that live in relatively unpolluted water. Ephemeroptera (mayfly species) was found as the predominant insect with Trichoptera (caddisfly) and Diptera (two-winged insects) next in abundance.

\section{SUMMARY}

The analysis of the waste-assimilative capacity of the Yampa River from Steamboat Springs to Hayden indicated that nonionized ammonia-nitrogen concentrations may exceed proposed stream standards on peak-population days. Based upon this analysis, concentrations of dissolved oxygen, fecal-coliform bacteria, total nitnogen, and nitrate nitrogen would not exceed current or proposed stream standards for the projected waste loading. The computed concentrations were based on population projections for 2010 and inflow to the proposed regional wastewater-treatment plant at Steamboat Springs of 134 gal $\left(0.509 \mathrm{~m}^{3}\right)$ per capita per day. Both December and September streamflow conditions and different population projections were considered. For December, a peak-day population of approximately 26,000 was used and, for September, a permanent population of approximately 11,500 was considered. Critical-period streamflow conditions in the study reach were assumed for all analyses to be related to the 7-day low flow with 10-year-recurrence interval (28 $\mathrm{ft}^{3} / \mathrm{s}$ or $\left.0.78 \mathrm{~m}^{3} / \mathrm{s}\right)$. The regionalized Q7,10 flow estimated for tributaries flowing into the study reach should be considered only as fair to poor in accuracy (Livingston, 1970). A 20- $\mathrm{ft}^{3} / \mathrm{s}\left(0.56-\mathrm{m}^{3} / \mathrm{s}\right)$ flow augmentation from the proposed Yamcolo Reservoir also was considered. A permissible increase in waste load of approximately 25 percent was indicated by the modeling analysis for this amount of flow augmentation.

Model calibration of this study reach was done using two models--the U.S. Geological Survey and the Pioneer-I steady-state water-quality models. The primary purpose of applying two models was to show differences in the computational algorithms used by the models for the corresponding model-parameter values. Modeling comparisons included concentrations of: Total nitrogen, nitrite nitrogen, ammonia nitrogen, nitrate nitrogen, orthophosphate, carbonaceous biochemical oxygen demand, dissolved oxygen, and fecal-coliform bacteria. The basic framework of both models was developed utilizing the Streeter and Phe1ps (1925) oxygen-sag equation.

The calibration results for this study are considered fair. The fitting procedure basically involved manually adjusting the nine model parameters in the U.S. Geological Survey and Pioneer-I models to fit the observed data with a minimum difference between the observed and modeled concentrations. Resultant profiles of concentrations for carbonaceous biochemical oxygen demand, dissolved oxygen, fecal-coliform bacteria, and total nitrogen agreed closely for the two models. The computed concentrations of organic nitrogen, nitrite nitrogen, nitrate nitrogen, and orthophosphate agreed closely for the U.S. Geological Survey and the Pioneer-I models for subreaches between sites YM-01 and $Y M-8$. Downstream from site $Y M-8$, there were some differences noted in the computed values. The differences in the computed concentrations of organic 
nitrogen, ammonia nitrogen, and orthophosphate could not be explained. The higher computed concentrations of nitrite-plus-nitrate nitrogen by the Pioneer-I model were explained by its accumulation of nitrogen in the nitrate form.

For the simulation phase of the study, the U.S. Geological Survey model was used. This choice was made because of previous experience with the model, the ease with which it can be used, and the form of the required data.

Several major factors were considered in the model simulations--for example, existing stream-reach classifications, suggested standards for effluent from a proposed regional wastewater-treatment plant, and Steamboat Springs area population projections. The stream reach has been classified by the State of Colorado as a cold-water-fishery secondary-body-contact type B1 (Colorado Department of Health, 1974). With this classification, there are various water-quality requirements. For the simulation phase, it was assumed that all model parameters were only temperature dependent. Therefore, for example, the simulation for December basically assumed the same biologic and $\mathrm{pH}$ conditions as in september. The amount of error induced because of this and other assumptions is not known.

A regional wastewater-treatment plant is proposed in the Steamboat Springs area (U.S. Environmental Protection Agency, 1977). There are four alternative proposals for the location of the plant site and type of treatment to be used. Two alternative proposals involve extended aeration and advanced wastewater treatment. The other two alternative proposals involve mixed advance waste treatment and include land treatment during a part of each year. This report considered only the alternatives which included extended aeration and advanced waste treatment. The land treatment of the other alternatives can produce nonpoint surface runoff which this study framework has no means to evaluate. Suggested effluent standards for 1978, 1983, and 1985 were considered in the analysis.

The population projections considered in this analysis (Gathers and Associates, 1976; U.S. Environmental Protection Agency, 1977) are considered only as indications of future growth. Because of the uncertainty of population projections, estimates for 2010 were used for the entire analysis. This promoted a maximum loading viewpoint of the stream reach from the proposed regional wastewater-treatment plant (U.S. Environmental Protection Agency, 1977).

A concurrent assessment of periphyton and macroinvertebrates was conducted cooperatively for the 16 main-stem locations by the U.S. Environmental Protection Agency and U.S. Geological Survey. A possible relation between the benthic-invertebrate diversity index and several nutrient concentrations was compared with the mean diversity data and resulted in relatively high correlation coefficients of $r=0.7$ for ammonia nitrogen and $r=0.6$ for orthophosphate. Periphyton data collected at the 16 main-stem locations indicated low correlation with the nutrient concentrations observed in the stream reach. 


\section{REFERENCES}

Ames, E. L., 1977, Aquatic insects in two western slope rivers, Colorado: Colorado State Univ., Dept. Zoology-Entomology, unpub. M.S. thesis, June $1977,95 \mathrm{p}$.

Bauer, D. P., and Jennings, M. E., 1975, Steady-state segmented dissolvedoxygen mode1: Bay St. Louis, Miss., U.S. Geo1. Survey Computer Contr., available only from U.S. Dept. Commerce, Nat1. Tech. Inf. Service, PB-241 $779,104 \mathrm{p}$.

Bennett, J. P., and Rathbun, R. E., 1972, Reaeration in open-channel flow: U.S. Geol. Survey Prof. Paper 737, 75 p.

Boning, C. W., 1974, Generalization of stream travel rates and dispersion characteristics from time-of-travel measurements: U.S. Geol. Survey Jour. Research, v. 2, no. 4, p. 495-499.

Colorado Department of Health, 1974, Water quality standards and stream classification: Colorado Dept. Health, Water Quality Control Div., 52 p.

Eddy, R. M., 1975, The effect of point source discharges on the diversity of benthic invertebrates of the Yampa River, Steamboat Springs to Hayden, Colo., September 1975: Denver, Colo., U.S. Environmental Protection Agency, Region VIII, 35 p.

Gathers and Associates, Inc., 1976, Comprehensive plan for Routt County, Colorado: Steamboat Springs, Colo., Routt County Plan. Dept., 500 p. [In press.]

Giles, T. F., and Brogden, R. E., 1977, Selected hydrologic data, Yampa River basin, and parts of the White River basin, northwestern Colorado and south-central Wyoming: U.S. Geol. Survey Open-File Rept. 78-23. [In press.]

Hines, W. G., McKenzie, S. W., Rickert, D. A., and Renella, F. A., 1977, Dissolved oxygen regime of the Willamette River, Oregon, under conditions of basinwide secondary treatment: U.S. Geol. Survey Circ. 715-I. [In press.]

Hines, W. G., Rickert, D. A., McKenzie, S. W., and Bennett, J. P., 1975, Formulation and use of practical models for river-quality assessment: U.S. Geol. Survey Circ. 715-B, p. B1-B13.

Jennings, M. E., and Bauer, D. P., 1976, Determination of biochemical oxygen demand parameters: Bay.St. Louis, Miss., U.S. Geol. Survey Computer Contr., available only from U.S. Dept. Commerce, Natl. Tech. Inf. Service, $\mathrm{PB}-253739,55 \mathrm{p}$.

Jennings, M. E., and Bryant, C. T., 1973, Water quality modeling for waste load allocation studies in Arkansas, stream dissolved oxygen and conservative minerals: U.S. Geol. Survey open-file report, 16 p.

Kittrel1, F. W., 1969, A practical guide to water-quality studies of streams: U.S. Dept. Interior, Federal Water Polution Control Adm., CWR-5, 135 p.

Livingston, R. K., 1970, Evaluation of the streamflow data program in Colorado: U.S. Geol. Survey open-file report, 72 p.

Mahloch, J. R., 1973, An investigation into modeling technique for coliform organisms in fresh water streams: Mississippi State Univ., Dept. Civil Eng., $36 \mathrm{p}$.

McCa11-Ellingson and Morril1, Inc., 1974, Water quality management plan for the Green River basin: Report for the Colorado Dept. Health, Water Quality Control Div., Denver, Colo., April 1974, 142 p. 
National Academy of Sciences-National Academy of Engineering, 1973, Water quality criteria, 1972: U.S. Environmental Protection Agency Rept. EPAR3-73-033, $594 \mathrm{p}$.

Rickert, D. A., and Hines, W. G., 1975, A practical framework for riverquality assessment: U.S. Geo1. Survey Circ. 715-A, 17 p.

Shindala, Adnan, 1972, Mathematical modeling for water quality management in streams and estuaries: Mississippi State Univ., Dept. Civil Eng., August $1972,62 \mathrm{p}$.

Skarheim, H. P., 1973, Tables of the fraction of ammonia in the undissociated form for $\mathrm{pH} 6$ to 9 , temperature $0-30^{\circ} \mathrm{C}$, TDS $0-3000 \mathrm{mg} / \mathrm{L}$, and salinity $5-$ $35 \mathrm{~g} / \mathrm{kg}$ : California Univ., Berkeley, College of Eng., School of Public Health, Sanitary Eng. Research Lab., SERL rept. 73-5, 33 p.

Slack, K. V., Averett, R. C., Greeson, P. E., and Lipscomb, R. G., 1973, Methods for collection and analysis of aquatic biological and microbiological samples: U.S. Geol. Survey Techniques Water-Resources Inv., book 5, chap. A4, 165 p.

Steele, T. D., Bauer, D. P., Wentz, D. A., and Warner, J. W., 1976a, An environmental assessment of impacts of coal development on the water resources of the Yampa River basin, Colorado and Wyoming--Phase-I work plan: U.S. Geol. Survey Open-File Rept. 76-367, 17 p.

Steele, T. D., James, I. C., II, Bauer, D. P., and others, 1976b, An environmental assessment of impacts of coal development on the water resources of the Yampa River basin, Colorado and Wyoming--Phase-II work plan: U.S. Geol. Survey Open-File Rept. 76-368, 33 p.

Streeter, H. W., and Phelps, E. B., 1925, A study of the pollution and natural purification of the Ohio River: Washington, U.S. Public Health Service Bu11. 146, 75 p.

Texas Water Development Board, 1970, Simulation of water quality in streams and canals, in Program documentation and users manual: Austin, Tex., DOSAG-I, $51 \mathrm{p}$.

Thomann, R. V., 1972, System analysis and water quality management: Environmental Sci. Services, 286 p.

URS/Ken R. White Company, 1975, Arkansas River basin, water quality management plan: Report for the Colorado Department of Hea1th, Denver, Colo.

U.S. Department of the Interior, 1976, Final environmental statement, northwest Colorado coal: Regional analysis and 5 site-specific analyses, December $1976,4 \mathrm{v}$.

U.S. Environmental Protection Agency, 1976, Quality criteria for water: U.S. Environmenta1 Protection Agency Rept. EPA-440/9-76-023, 501 p.

1977, Steamboat Springs Regional Service Authority, 201 Wastewater facilities plan--Final environmental impact statement: Region VIII, Denver, Colo., prepared by Weiner \& Assoc., Rept. EPA-908/5-77-005, August 1977, $243 \mathrm{p}$.

Velz, C. J., 1970, Applied stream sanitation: New York, John Wiley \& Sons, Inc., $619 \mathrm{p}$.

Waddel, W. W., Cole, C. R., and Baca, R. G., 1973, A water quality model of the South Platte River basin--Documentation report: Richland, Wash., Battelle Pacific Northwest Labs., 44 p. 
Wentz, D. A., and Steele, T. D., 1976, Surface-water quality in the Yampa River basin, Colorado and Wyoming--An area of accelerated coal development: Paper presented at Conf. on Water for Energy Deve1., Eng. Found., Asilomar Conf. Grounds, Pacific Grove, Calif., Dec. 5-10, 1976, $28 \mathrm{p}$.

Western Engineers, Inc., 1975, Yamcolo Reservoir project--Feasibility report: Denver, Colo., 75 p.

Willingham, Tom, 1976, Ammonia toxity: Denver, U.S. Environmental Protection Agency, Region VIII.

Willis, Robert, Anderson, D. R., and Dracup, J. A., 1975, Steady-state water quality modeling in streams: Am. Soc. Civil Engineers, Jour. Environmental Eng. Div., v. 101, no. EE2, p. 245-258.

Wright, K. R., 1976, Sewage effluent turned to snow, provides storage, removes pollutants: Am. Soc. Civil Engineers, Civil Eng., May 1976, p. 88-89. Wright-McLaugh1in Engineers, 1974, Sewage effluent renovation in mountain meadows: Steamboat Springs, Colo., Timbers Water and Sanitation Dist., $65 \mathrm{p}$. 
